\title{
RESUMOS DE DISSERTAÇÕES DE MESTRADO E TESES DE DOUTORADO APRESENTADAS NA FACULDADE DE MEDICINA DE RIBEIRÃO PRETO - USP DE ABRIL A JUNHO DE 2005
}

\section{BIOLOGIA CELULAR E MOLECULAR}

\begin{abstract}
MICROARRANJO DE DNA DE CLONES ORESTES PERMITE A IDENTIFICAÇÃO DE NOVOS GENES COM EXPRESSÃO DIFERENCIAL NA PROGRESSÃO TUMORAL DE MELANOMA
\end{abstract}

\section{Kamila Chagas Peronni}

Orientador: Profa.Dra. Enilza Maria Espreafico

Dissertação de Mestrado apresentada em 29/04/2005

A progressão tumoral é um processo complexo que envolve alterações em diversas vias celulares. Muitas ESTs (expressed sequence tags) depositadas nos bancos de dados correspondem a genes de função desconhecida e um grande número destas pode estar envolvido na progressão tumoral. No presente projeto, 90.000 ORESTES (Open Reading Frame ESTS) geradas no Projeto Genoma Humano do Câncer pelos laboratórios RC1 e RC3 foram submetidas à Blast contra o banco de seqüências referência (16546 Refseqs do NCBI), permitindo a seleção de 1584 grupos de seqüências que alinharam (E-value $=10^{-100}$, extensão $>$ que $95 \%$ do seu tamanho) com refseqs das categorias preditas ou provisórias (representando preferencialmente genes com pouca ou nenhuma caracterização funcional). Destes grupos, selecionamos através do programa Blat (http://genome.ucsc.edu/cgi-bin/hgBlat) as seqüências com a maior extensão de alinhamento e posicionadas mais à 3' no transcrito, resultando em uma coleção de 1207 sequiências, sendo 351 correspondentes a refseqs preditas e 856 provisórias. Os respectivos clones foram utilizados na confecção de um microarranjo de DNA empregado no estudo da expressão comparati- va entre duas linhagens celulares de melanoma provenientes do mesmo paciente, sendo uma (WM278) derivada do tumor primário (fase vertical da progressão tumoral) e a outra (WM1617) da metástase deste tumor em linfonodo (Meenhard Herlyn's laboratory, http://www.wistar.upenn.edu/herlyn/). Após quantificação digital e análise estatística dos microarranjos, foram detectados 5 genes superexpressos e 75 genes subexpressos na linhagem metastática em relacão à linhagem de progressão vertical. A análise de um grupo desses genes por Northern blot contendo RNA total do mesmo par de linhagens de melanoma mais uma linhagem do estágio de progressão radial (WM1552) mostrou que os genes LRPAP1 e o CD63 apresentam-se superexpressos na linhagem metastática em relação às outras duas linhagens de tumor primário analisadas. Dentre os genes com subexpressão confirmada na linhagem metastática, destacaram-se os genes CYR61, BUB3, HMGN2 e MGC5576 com diferenças marcantes de expressão. Os resultados de Northern blots indicaram também expressão aumentada dos genes TRAI, HMGN2, PEA15, HSPCA, C70RF28B, MGC13186 e FLJ20397 na linhagem radial WM1552 em comparação às outras duas. Condizente com estes resultados, estudos atuais da expressão gênica em grande escala indicam a maior frequência de supressão do que de superexpressão gênica na transição para metástase.

\section{CARACTERIZAÇÃO GENÉTICA E MOLECULAR DE UM TRANSCRITO DA REGIÃO CITOGENÉTICA 3F DE DROSOPHILA MELANOGASTER E SUA RELA- ÇÃO COM OS LOCI ECHINUS E ROUGHEST}

Giuliana Cristina Marre Bruschi Thedei

Orientador: Prof.Dr. Ricardo G. Pinheiro Ramos

Tese de Doutorado apresentada em 23/05/2005
A formação da retina de Drosophila envolve processos como proliferação, diferenciação e morte celular, resultando em todos os tipos celulares carac- 
terísticos dessa estrutura e levando ao padrão extremamente organizado de cada omatídia. Mutações que perturbam a morte celular na retina resultam num excesso de células e na desorganização do arranjo das omatídias no olho adulto resultando num olho rugoso, fenótipo que se observa nos mutantes echinus (ec) e roughest (rst). Dessa maneira, a caracterização de ec pode contribuir para uma melhor compreensão do processo de morte celular na retina. A análise da região $3 \mathrm{~F}$ do cromossomo $\mathrm{X}$, visando identificar uma unidade de transcrição correspondente a echinus, levou ao isolamento e caracterização de um cDNA (GH07910) correspondente a uma serina treonina kinase (BDGP) que se mostrou alterada nos mutantes $e c$. Essa serina treonina kinase foi relacionada ao gene anotado CG2829, que apresenta dois transcritos que diferem no primeiro éxon e na região $3^{\prime}$ não traduzida, sendo um deles este que isolamos (GH07910). Foram geradas três linhagens transgênicas independentes para esse
cDNA. A expressão de GH07910 no olho composto de linhagens selvagens, resultou em um fenótipo de olho rugoso com severa desorganização da estrutura das omatídias em relação ao padrão selvagem, sugerindo que o mesmo possa participar do processo de formação dessa estrutura. A expressão desse cDNA em mutantes echinus não resultou em complementação do fenótipo do olho composto, sugerindo que não esteja relacionado com essa mutação. Em mutantes roughest, a expressão de GH07910 produziu olhos compostos com a estrutura bastante comprometida, com desorganização das omatídias e perda de pigmentação. A expressão simultânea no olho composto de linhagens selvagens da serina treonina kinase isolada (GH07910) e de um gene recentemente associado a echinus que codifica uma ubiquitina tiolesterase, resultou num fenótipo severo de desorganização das omatídias, no entanto somente estes resultados não permitem ainda estabelecer uma relação entre essas proteínas.

\section{A INJEÇÃO INTRAPERITONEAL DE LECTINAS INDUZ O RECRUTAMENTO DE MASTÓCITOS PARA O MESENTÉRIO}

\section{Patrícia Andressa de Almeida Buranello \\ Orientador Prof. Dr. Constance Oliver \\ Dissertação de Mestrado apresentada em 25/05/2005}

Os mastócitos são células imunorreguladoras que participam dos mecanismos de defesa do organismo e são conhecidos por exercerem um papel fundamental em reações alérgicas, inflamatórias, asmáticas como também na eliminação de parasitas. Os mediadores liberados pela desgranulação dos mastócitos são responsáveis pela atuação destas células em reações inflamatórias e processos imunológicos. A vasta utilização de alimentos vegetais pouco processados resulta num alto índice de compostos intactos, não nutritivos, como as lectinas, as quais podem desencadear processos alérgicos e até estimular a liberação de mediadores dos mastócitos. Os resultados de nosso estudo mostraram que $10 \mu \mathrm{g} /$ animal das lectinas Com A, WGA, KM+, jacalina e euphorbina não causa desgranulação de mastócitos de mesentério de rato in vitro. Além disso, $10 \mu \mathrm{g} / \mathrm{animal}$ da lectina Con A não causou desgranulação dos mastócitos mas aumentou o número de mastócitos imaturos no me- sentério, sete dias após a injeção. Resultado semelhante foi obtido com $200 \mu \mathrm{g} / \mathrm{animal}$, que promove desgranulação de mastócitos de mesentério. Estes dados sugerem que o processo de recrutamento de mastócitos pela lectina Con A ocorre independentemente da liberação de fatores quimiotáticos resultantes da desgranulação dos mastócitos. Para testar esta hipótese, a lectina $\mathrm{KM}+$, Con A, WGA, jacalina e euphorbina foram injetadas IP em ratos que tiveram a cavidade peritoneal depletada de mastócitos pela injeção de água destilada. Sete dias após a injeção de lectinas todos os animais apresentaram um número menor de mastócitos imaturos de mesentério em relação aos animais injetados somente com água destilada. Neste mesmo tempo, a porcentagem de mastócitos imaturos no mesentério de ratos injetados com $\mathrm{KM}+$ foi de apenas $82,23 \%$ do número encontrado no controle. Com a lectina Con A a porcentagem de mastócitos foi de somente $14 \%$ do número encontrado em animais injetados com água destilada. Os fragmentos de mesentério de ratos injetados com WGA, jacalina e euphorbina apresentaram um número de mastócitos imaturos inferior ao controle e intermediários àqueles encontrados para $\mathrm{KM}+$ e Con $\mathrm{A}$. O número de mastócitos 
maduros encontrado em mesentério de animais tratados com Con A foi 5,4 vezes maior que o controle, e animais injetados com WGA, jacalina e euphorbina, foi 5,3; 5 e 4,3, respectivamente, maior que o controle. Nossos achados sugerem que todas as lectinas são capazes de induzir ao recrutamento de mastócitos para repovoar o mesentério de rato, independente de causar a sua desgranulação e também que a lectina KM+ é a mais eficiente no recrutamento de mastócitos. Investigamos, também, a população de mastócitos da medula óssea durante o repovoamento do mesentério. Os resultados mostram que as lectinas Con A e
$\mathrm{KM}+$, além de induzirem um aumento do número de mastócitos imaturos no mesentério, também promovem um aumento no número de mastócitos AA4+ (bem imaturos, imaturos e maduros) na medula óssea. Nossos dados demonstram que a lectina $\mathrm{KM}+$, dentre as lectinas estudadas, é a mais eficiente em recrutar mastócitos para repovoar o mesentério de rato, o que confere a esta lectina um papel quimiotático. A lectina $\mathrm{KM}+$ se constitui numa ferramenta de grande importância para o estudo de processos que envolvem o recrutamento de mastócitos e de outras células do sistema imunológico.

\section{CLÍNICA CIRÚRGICA}

\section{ANATOMIA MICROCIRÚRGICA DAS ARTÉRIAS DURAIS}

\section{Maria Carolina Martins de Lima}

Orientador: Prof. Dr. Benedicto Oscar Colli

Tese de Doutorado apresentada em 06/05/2005

Objetivo: Avanços recentes no tratamento microcirúrgico e endovascular de lesões envolvendo as artérias durais têm determinado a necessidade de uma compreensão aprofundada dessa rede vascular complexa. Este estudo tem por objetivo examinar a anatomia microcirúrgica das artérias durais. Métodos: Espécimes cadavéricos adultos (segmentos cefálicos) e crânios foram o instrumento deste trabalho. Ambos foram dissecados e/ou examinados utilizando a magnificação do microscópio cirúrgico para definir origem, curso e distribuição dos ramos durais individuais. As dissecções foram registradas através de imagens tridimensionais. Os principais ramos durais foram agrupados didaticamente dentro dos sistemas carotídeo externo e interno e vértebro-basilar. Os achados de dissecção foram associados aos dados compilados da literatura e ambos foram base para a proposição de mapas de distribuição territorial dos ramos durais. Resultados: O padrão de distribuição dos ramos durais na base do crânio é bem mais complexo que aquele da convexidade. A artéria carótida interna supre a dura da porção medial das fossas anterior e média e o limite anterior da fossa posterior. O sistema da carótida externa supre o segmento lateral da dura das três fossas cerebrais, enquanto o sistema vértebrobasilar supre a dura da porção medial da fossa posterior e aquela ao redor do forame magno. Os territórios durais frequientemente têm um suprimento arterial superponível a partir de várias fontes. Exemplos de áreas com suprimento múltiplo superponível são a dura da região parasselar, o tentório e a foice. O tentório e a foice também recebem contribuições a partir das artérias cerebrais, o que torna essas estruturas importantes vias anastomóticas entre as artérias durais e parenquimatosas. Na rede arterial dural, é comum a existência de uma relação de reciprocidade entre os ramos meníngeos. Nesse tipo de relação, há expansão do território de uma artéria se o vaso adjacente é hipoplásico e vice-versa. Conclusão: A rede arterial dural consiste em um sistema vascular complexo, composto por elementos dos três sistemas arteriais cranianos. Essa rede é marcada por intensa variabilidade, superposição de fontes nutridoras em um mesmo território e relacionamento de reciprocidade entre seus ramos. $\mathrm{O}$ conhecimento da anatomia microcirúrgica das artérias durais e sua avaliação pré-tratamento desempenham um papel crucial para um tratamento neurocirúrgico seguro e eficaz. 


\section{INFLUÊNCIA DA TRANSFECÇÃO DO GENE cdkn2a NO PERFIL DE EXPRESSÃO GÊNICA DE UMA LINHAGEM CELULAR DE GLIOBLAS- TOMA HUMANO}

\section{Sérgio Vicente Serrano}

Orientador: Prof. Dr. Carlos Gilberto Carlotti Jr.

Tese de Doutorado apresentada em 09/05/2005

Os astrocitomas difusos, neoplasias com alta frequiência no sistema nervoso central (SNC), são classificados histologicamente em tumores de baixo e alto grau. Os astrocitomas difusos de baixo grau são tumores de crescimento lento que possuem tendência inerente para a progressão para astrocitomas de alto grau, chamados de astrocitoma anaplásico (AA) e glioblastoma multiforme (GBM), caracterizados por um índice de proliferação celular elevado, grande capacidade de invasão e aumento da proliferação microvascular. O conhecimento sobre as alterações genéticas relacionadas à biologia molecular das neoplasias do sistema nervoso central (SNC), embora vem aumentando nos últimos anos, é ainda limitado. O gene supressor tumoral $C D K N 2 A$, o qual codifica a proteína p16 (função reguladora do ciclo celular), está freqüentemente alterado nos astrocitomas difusos. Neste estudo, analisou-se o perfil de expressão gênica de uma linhagem de GBM, U343, deficiente em CDKN2A, a qual foi transfectada com o referido gene, associado a um promotor inibido na presença de tetraciclina. Utilizando-se uma membrana de macroarray, contendo cDNA de 597 genes relacionados a cancer, comparou-se o perfil de expressão das células U343, antes e após a indução de expressão de $C D K N 2 A$. Observou-se aumento de expressão de 10 genes após a indução de expressão de $C D K N 2 A$ (NME4, CDH5, RAD23A, CCNB1, TIMP-1, ADAM17, CDKN2D,
GSTO1, RPS9 e RAC1). Além disso, sete genes apresentaram diminuição de expressão ( $R X R B, I T G B 8$, GADD153, CD59, TIMP-3, PIN1 e ITGB7). Para confirmação destes resultados, realizou-se reação de PCR em tempo real, quantitativa (RQ-PCR) para 3 genes cuja expressão aumentou (CDH5, TIMP-1 e $A D A M 17)$ e de 3 genes cuja expressão foi reduzida (ITGB8, TIMP-3 e ITGB7) após a indução de expressão de $C D K N 2 A$. A análise por RQ-PCR, ao contrário da análise por macroarray, demonstrou que a expressão dos diferentes genes de moléculas de adesão (CDH5, TIMP-1, ADAM17, ITGB8, e ITGB7) apresentou variação importante, conforme o momento da extração de RNA, após a indução de expressão de $C D K N 2 A$, de forma aleatória, porém sem relação com o nível de expressão de $C D K N 2 A$. A expressão destes genes aparentemente é influenciada por outros fatores, tais como a interação célula-célula em condições de cultura. Assim, as discrepâncias entre os resultados obtidos na análise por macroarray e por RQ-PCR podem ser causadas por fatores biológicos e não metodológicos. Por outro lado, tanto na análise por RQ-PCR, como por macroarray, observou-se que a expressão de TIMP3 foi inversamente relacionada a expressão de $C D K N 2 A$. Estes resultados sugerem que $C D K N 2 A$, pode influenciar a expressão de TIMP3, e possivelmente de outros genes. Desta forma, apesar de sua função principal estar relacionada à regulação do ciclo celular, $C D K N 2 A$ pode influenciar outros aspectos da biologia molecular das neoplasias do SNC, incluindo, possivelmente alguns dos mecanismos de invasão tumoral.

\section{EFEITO DA IRRADIAÇÃO LASER SOBRE A REGENERAÇÃO HEPÁTICA DE RATOS CIRRÓTICOS HEPATECTOMIZADOS}

\section{Adriana Augusta Lopes de Araújo Lima}

Tese de Doutorado apresentada em 20/05/2005

Orientador: Prof. Dr. Orlando de Castro e Silva Jr.

O laser é um agente físico que interage com os sistemas orgânicos e a fotobioestimulação baseia-se no nível mais sutil de interação da luz com tecidos, em que o fóton transmite sua energia a um composto fotossensível. O objetivo do presente estudo foi verificar o efeito da irradiação laser sobre a regeneração hepática, após a hepatectomia parcial a 30\% em ratos cirróticos. Ratos Wistar adultos foram submetidos à ligadura do ducto biliar, esperando-se 4 semanas para a obtenção de cirrose biliar secundária. Os animais 
foram subdivididos em quatro grupos: controle cirrótico, cirróticos hepatectomizados, cirróticos irradiados, cirróticos hepatectomizados e irradiados. Foram estudados três grupos de animais não cirróticos para comparação: controle normal, hepatectomizados, hepatectomizados e irradiados. Em todos os grupos, o sacrifício dos animais foi realizado $24 \mathrm{~h}$ após os procedimentos (hepatectomia parcial e/ou irradiação laser). A regeneração hepática foi estimada através do índice de proliferação de hepatócitos, utilizando o método imunohistoquímico para o PCNA ("proliferating cell nuclear antigen”). A análise estatística para comparação global entre os grupos foi feita pelo teste de KruskallWallis e para comparação dois a dois entre os grupos utilizou-se o teste U de Mann-Whitney. O índice de proliferação de hepatócitos foi maior nos animais cirróticos que foram hepatectomizados e irradiados em relação aos grupos cirrótico controle, cirrótico hepatectomizado, cirrótico irradiado e não cirróticos. Não houve diferença entre o grupo cirrótico que foi somente hepatectomizado comparado àquele somente irradiado. Entre os grupos não cirróticos, os animais que foram hepatectomizados e irradiados apresentaram valores estatisticamente maiores. Este estudo demonstrou que o uso de laser combinado à hepatectomia a $30 \%$ determinou significativo incremento na atividade regenerativa do fígado tanto em ratos cirróticos quanto não cirróticos.

\section{TRATAMENTO DA PERITONITE BACTERIANA GRAVE EM RATOS : AVALIA- ÇÃO DO PAPEL DA ANTIBIOTICOTERAPIA E DOS ACESSOS POR LAPARO- TOMIA E VIDEOLAPAROSCOPIA}

\section{Wilson Salgado Júnior \\ Orientador: Prof. Dr. José Sebastião dos Santos \\ Tese de Doutorado apresentada em 27/06/2005}

O tratamento da peritonite bacteriana por meio da videolaparoscopia ainda é motivo de investigação. O objetivo deste estudo é avaliar o papel da antibioticoterapia e dos acessos videolaparoscópico e laparotômico no tratamento da peritonite bacteriana grave, em ratos.

Foram operados 64 ratos Wistar machos, alocados de forma equiitativa em 8 grupos: Cirurgia simulada (CS), CS+antibiótico (CS +atb), Ligadura do Ceco com Punção (LCP), LCP+atb, Videolaparoscopia (VLAP), Laparotomia (LAP), VLAP+atb, LAP+atb. Todos os animais tratados foram submetidos a avaliação da bacteremia, da leucometria, e dosagens de citocinas (IL-1, IL-6, TNF-alfa). Os grupos tratados com antibiótico, receberam gentamicina e metronidazol. A sobrevida foi avaliada durante sete dias.

A peritonite induzida pela técnica de LCP foi grave, com sobrevida média de 30 horas. As taxas de IL-1, IL-6 e TNF alfa no grupo LCP foram, em pg/ml, respectivamente de, 139,91 $\pm 92,35,1171,70 \pm 900,18$ e 253,19 $\pm 293,25$, significativamente maiores em relação ao grupo CS, cujos valores respectivos foram em $\mathrm{pg} / \mathrm{ml}$ de $50,51 \pm 19,92,22,30 \pm 26,16$ e $51,87 \pm 54,13$. No grupo LCP+atb, os valores de IL-1, IL-6 e TNFalfa foram, em pg/ml, respectivamente de, 168,57 \pm $124,51,1171,05 \pm 484,85$ e $189,16 \pm 184,47$ e não diferiram do grupo LCP. Por outro lado, naquele grupo a sobrevida foi de $120 \pm 42,54$ horas, significativamente maior que no grupo LCP. Não houve diferenças significativas entre a sobrevida e as taxas de IL-1, IL-6 e de bacteremia entre os tratamentos por videolaparoscopia e laparotomia. Os níveis de TNF foram mais elevados no grupo VLAP $(479,63 \pm 509,67 \mathrm{pg} / \mathrm{ml}) \mathrm{em}$ comparação ao grupo LAP $(150,64 \pm 81,62 \mathrm{pg} / \mathrm{ml})$ $(\mathrm{p}=0,0499)$. Observou-se, ainda, que o valor médio de IL-6 nos animais VLAP $(2061,50 \pm 481,74 \mathrm{pg} / \mathrm{ml})$ foi maior que no grupo LCP $(1171,70 \pm 900,18 \mathrm{pg} / \mathrm{ml})$ $(\mathrm{p}=0,0499) . O$ acréscimo da antibioticoterapia (VLAP+atb), fez com que o valor médio da IL-6 nesse grupo $(1334,48 \pm 624,36 \mathrm{pg} / \mathrm{ml})$ fosse menor que o do grupo VLAP ( $\mathrm{p}=0,0281)$. A sobrevida no grupo VLAP+atb foi de $116,25 \pm 74,02 \mathrm{~h}$, significativamente maior que no grupo LCP ( $p=0,0499)$, chegando a se igualar com a sobrevida do grupo CS (168 horas).

Conclui-se que a antibioticoterapia aumenta a sobrevida de ratos com peritonite generalizada grave, minimiza a resposta inflamatória sistêmica secundária ao pneumoperitôneo, conferindo melhor desempenho à associação entre videolaparoscopia e antibioticoterapia. 


\section{CLÍNICA MÉDICA}

\section{AVALIAÇÃo dAS ALTERAÇÕES CAUSADAS PELA RADIOTERAPIA E PELA INVASÃO TUMORAL NA SUBSTÂNCIA BRANCA CEREBRAL ATRAVÉS DA QUANTIFICAÇÃO DA TRANSFERÊNCIA DE MAGNETIZAÇÃO}

José Daniel Vieira de Castro

Orientador: Prof. Dr. Antônio Carlos dos Santos

Tese de Doutorado apresentada em 16/06/2005

Objetivos: Avaliar as alterações provocadas pela radioterapia (rxt) na substância branca cerebral de pacientes com glioma cerebral, bem como as alterações na substância branca cerebral peritumoral, utilizando o índice de transferência de magnetização (MTR). Método: vinte e cinco pacientes com gliomas infiltrativos foram avaliados com ressonância magnética, acrescentando-se ao protocolo de estudo duas sequiências GRE T1 co-registradas, idênticas, exceto por um pulso de transferência de magnetização aplicado a uma delas (MTnoSat e MTSat). A partir dessas duas seqüências foi gerado um mapa de índice de transferência de magnetização (MTR) através da fórmula: MTR = (1- [seqüência MTsat / seqüência MTnoSat]) $\boldsymbol{x}$ 100. Neste mapa foram realizadas medidas do MTR através da seleção manual de regiões de interesse. Foram medidos o MTR do corpo caloso e da substância branca cerebral aparente- mente normal antes e após a rxt. Somente antes da cirurgia e da rxt foram medidos MTR do tumor, da substância branca peritumoral alterada e da substância branca cerebral próxima e distante ao tumor, ipsilateral à lesão e contra-lateral à lesão. Os resultados foram analisados pelo teste da mediana de WILCOXON. Resultados: Houve uma redução significativa do MTR do corpo caloso e da substância branca cerebral aparentemente normal após a radioterapia. Antes de qualquer tratamento, o MTR da substância branca aparentemente normal próxima ao tumor estava menor que o MTR da substância branca distante ao tumor, e o MTR da substância branca aparentemente normal contra-lateral à lesão estava maior que o da ipsilateral a lesão. Conclusões: 1) O MTR é capaz de detectar alterações precoces da substância branca após a rxt, sugerindo ser esta alteração relacionada com a destruição mielínica e/ou axonal. 2) O MTR distingue diferenças entre a substância branca aparentemente normal próxima e distante do tumor em níveis que sugerem alterações mielínicas além do edema.

\section{FARMACOLOGIA}

\section{FALÊNCIA DA MIGRAÇÃO DE NEUTRÓFILOS PARA O FOCO INFECCIOSO NA SEPSE POLIMICROBIANA: PAPEL DO RECEPTOR TOLL-LIKE 4}

\section{José Carlos Farias Alves Filho}

Orientador: Prof. Dr. Fernando de Queiroz Cunha

Dissertação de Mestrado apresentada em 08/04/2005

Sepse é uma resposta inflamatória sistêmica que resulta da inabilidade do sistema de defesa em controlar o crescimento bacteriano local durante uma in- fecção. Recentes estudos do nosso laboratório demonstraram que uma falência na migração de neutrófilos para o foco infeccioso é observada na sepse grave induzida por diferentes estímulos. Nestes estudos houve uma correlação positiva entre a falência da migração de neutrófilos, aumento dos níveis séricos de citocinas, bacteremia e aumento da mortalidade dos 
animais. Este comprometimento da migração de neutrófilos parece ser causado pela liberação sistêmica de citocinas com resultante produção de óxido nítrico, devido à entrada e conseqüente reconhecimento dos microorganismos ou de seus produtos na circulação. Um dos maiores avanços no entendimento dos eventos iniciais no reconhecimento microbiano foi à identificação dos receptores Toll-like (TLRs), sendo o TLR4 caracterizado como o receptor para o reconhecimento do LPS. Utilizando animais deficiente para o TLR4 $(\mathrm{C} 3 \mathrm{H} / \mathrm{HeJ})$, avaliamos o papel deste receptor no recrutamento de neutrófilos e na sobrevida dos animais após infecção Gram-negativa com Salmonella typhimurium. Além disso, avaliamos o papel do TLR4 também no desenvolvimento da falência da migração de neutrófilos para o foco infeccioso observada na sepse grave, bem como sua participação na sobrevivência dos animais após sepse polimicrobiana. Nossos resultados mostram que a deficiência na sinalização do TLR4 torna os animais $\mathrm{C} 3 \mathrm{H} / \mathrm{HeJ}$ mais susceptíveis a infecções causada por bactérias gram-ne- gativas, uma vez que não é possível reconhecer as bactérias presentes no foco infeccioso e assim promover um eficiente recrutamento de neutrófilos para o sítio da infecção. Por outro lado, durante uma infecção polimicrobiana, o TLR4 não é necessário para a indução do recrutamento de leucócitos, uma vez que os animais $\mathrm{C} 3 \mathrm{H} / \mathrm{HeJ}$ conseguem desenvolver uma competente resposta inflamatória, produzindo citocinas e quimiocinas e promovendo o recrutamento de neutrófilos, o qual conseqüentemente controla o processo infeccioso. No entanto, o receptor Toll-like 4 contribui para o desencadeamento dos efeitos sistêmicos deletérios observados quando ocorre a disseminação das bactérias e de seus produtos para a circulação, levando ao desenvolvimento da falência da migração de neutrófilos para o foco infeccioso e conseqüentemente morte dos animais. Desta forma, nossos resultados demonstram o papel deletério da sinalização do TLR4 durante a sepse grave polimicrobiana, sugerindo que antagonistas desse receptor poderiam ser úteis no tratamento desta patologia.

\section{PARTICIPAÇÃO DO ENDOTÉLIO VASCULAR NO RELAXAMENTO ATIVADO PELO AMP CÍCLICO NA AORTA DE RATOS HIPERTENSOS RENAIS 2 RINS - 1 CLIPE}

\section{Mário dos Anjos Neto Filho}

Orientadora: Profa. Dra. Lusiane Maria Bendhack

Dissertação de Mestrado apresentada em 26/04/2005

Agonistas $\beta$-adrenérgicos como a isoprenalina e terbutalina ativam receptores de membrana ligados à proteína Gs que produz 3' 5 ' - monofosfato de adenosina (AMPc) via adenilato-ciclase com conseqüente ativação da proteína quinase $\mathrm{A}$ (PKA). Por outro lado, a forscolina ativa diretamente a adenilato-ciclase. Nas células do músculo liso vascular, o aumento da produção de AMPc bem como a redução da concentração citoplasmática de $\mathrm{Ca}^{2+}\left(\left[\mathrm{Ca}^{2+}\right]_{\mathrm{c}}\right)$, promovem o relaxamento vascular. São propostas várias hipóteses para explicar os mecanismos de redução da $\left[\mathrm{Ca}^{2+}\right]_{\mathrm{c}}$ e o relaxamento vascular devido ação da PKA. Entre elas, a de que ocorre maior armazenamento de $\mathrm{Ca}^{2+}$ no retículo sarcoplasmático e/ou menor influxo de $\mathrm{Ca}^{2+}$.

Nosso trabalho teve por objetivo estudar o efeito relaxante estimulado com isoprenalina, terbutalina e forscolina e a contribuição do endotélio vascular para este relaxamento. Comparamos os efeitos dessas dro- gas em aortas de ratos normotensos (2R-SO) e hipertensos renais 2 rins - 1 clipe (2R-1C). Estudamos os efeitos destas drogas sobre o armazenamento de $\mathrm{Ca}^{+2}$ em estoque intracelular sensível à fenilefrina e sobre o influxo de $\mathrm{Ca}^{+2}$ do meio extracelular e a $\left[\mathrm{Ca}^{2+}\right]_{c}$ em células endoteliais estimuladas com isoprenalina, terbutalina ou forscolina.

$\mathrm{A} \mathrm{EC}_{50}$ da fenilefrina foi semelhante em aortas de ratos $2 \mathrm{R}-\mathrm{SO}$ e $2 \mathrm{R}-1 \mathrm{C}$ e assim, utilizamos a mesma concentração do agonista para pré-contração das preparações no estudo do relaxamento. O endotélio reduziu a resposta contrátil máxima estimulada com fenilefrina apenas em aortas de ratos $2 \mathrm{R}-1 \mathrm{C}$. O influxo de $\mathrm{Ca}^{+2}$ estimulado com fenilefrina ou o estoque intracelular de $\mathrm{Ca}^{+2}$ sensível à fenilefrina foram semelhantes em 2R-SO e em 2R-1C.

Isoprenalina, terbutalina e foscolina promoveram aumento da $\left[\mathrm{Ca}^{2+}\right]_{\mathrm{c}}$ nas células endoteliais. No caso da terbutalina e da forscolina o aumento foi maior em células de ratos $2 \mathrm{R}-\mathrm{SO}$ do que $2 \mathrm{R}-1 \mathrm{C}$, porém com isoprenalina este efeito foi semelhante entre os dois grupos. 
O relaxamento induzido com isoprenalina e forscolina foi maior em aortas de $2 \mathrm{R}-\mathrm{SO}$ do que de $2 \mathrm{R}$ 1C. A presença do endotélio potencializou o relaxamento estimulado com isoprenalina na aorta de $2 \mathrm{R}$ $\mathrm{SO}$ e $2 \mathrm{R}-1 \mathrm{C}$. Porém, com forscolina a potência foi maior em aortas com endotélio somente de 2R-1C. De forma interessante, a potência e o efeito máximo da terbutalina foram maiores em aortas de ratos $2 \mathrm{R}$ $1 \mathrm{C}$ do que de 2R-SO, com endotélio.

O estoque sensível à fenilefrina foi medido pela contração à fenilefrina em meio sem $\mathrm{Ca}^{+2}$. A isoprenalina e terbutalina reduziram a resposta contrátil à fenilefrina em aortas com endotélio de ratos $2 \mathrm{R}-\mathrm{SO}$ e 2R-1C. Porém, em aortas de ratos sem endotélio ambos agonistas reduziram o efeito máximo da fenilefrina somente em aortas de 2R-1C. A forscolina reduziu a resposta contrátil à fenilefrina em aorta de $2 \mathrm{R}-\mathrm{SO}$ sem endotélio e de $2 \mathrm{R}-1 \mathrm{C}$, com e sem endotélio.

$\mathrm{O}$ influxo de $\mathrm{Ca}^{+2}$ extracelular foi reduzido pelos agonistas isoprenalina e terbutalina em aortas com endotélio de 2R-SO e 2R-1C. Em aortas sem endotélio, o influxo de $\mathrm{Ca}^{+2}$ extracelular foi reduzido pelos agonistas somente em aortas de ratos $2 \mathrm{R}-1 \mathrm{C}$. A forscolina reduziu o influxo de $\mathrm{Ca}^{+2}$ extracelular em aortas de $2 \mathrm{R}-\mathrm{SO}$ e $2 \mathrm{R}-1 \mathrm{C}$, sem endotélio, e de forma surpreendente, a forscolina aboliu o influxo de $\mathrm{Ca}^{+2}$ extracelular em aorta com endotélio de 2R-SO e 2R-1C.

Estes resultados sugerem que o aumento de AMPc reduz o influxo de $\mathrm{Ca}^{+2}$ extracelular, e este efeito é potencializado pelo endotélio em aortas de $2 \mathrm{R}-$ $\mathrm{SO}$ e $2 \mathrm{R}-1 \mathrm{C}$. Porém, a inibição do influxo de $\mathrm{Ca}^{+2}$ pelos três agentes relaxantes ocorre também na ausência do endotélio somente em aorta de 2R-1C.

Em conjunto, nossos resultados demonstram que os agentes relaxantes estudados promovem aumento da $\left[\mathrm{Ca}^{2+}\right]_{\mathrm{c}}$ nas células endoteliais e relaxamento da aorta de ratos $2 \mathrm{R}-\mathrm{SO}$ e $2 \mathrm{R}-1 \mathrm{C}$. O relaxamento vascular estimulado com isoprenalina e terbutalina foi potencializado pelo endotélio em aortas de $2 \mathrm{R}-\mathrm{SO}$ e $2 \mathrm{R}-1 \mathrm{C}$, porém o efeito relaxante da forscolina foi maior somente em aortas com endotélio de ratos 2R-SO. O armazenamento de $\mathrm{Ca}^{+2}$ no estoque sensível à fenilefrina e o influxo de $\mathrm{Ca}^{+2}$ estimulado com fenilefrina foram reduzidos pelos agentes relaxantes estudados.

\section{FISIOLOGIA}

\section{PAPEL DO ÓXIDO NÍTRICO NA TOLERÂNCIA AO LPS EM CAMUNDONGOS}

\section{Mirela Barros Dias}

Orientador: Prof. Dr. Luiz Guilherme de Siqueira Branco

Dissertação de Mestrado apresentada em 25/04/2005

A injeção de doses repetidas de lipopolissacarídeo (LPS) resulta na atenuação da resposta febril, que é chamada de tolerância à endotoxina. Testou-se a hipótese que o óxido nítrico (NO) proveniente da enzima da NO sintase induzível (iNOS) participa da tolerância à endotoxina. Para tanto, utilizou-se não apenas a abordagem farmacológica, mas também camundongos geneticamente modificados. A temperatura corporal (Tc) foi mensurada por biotelemetria em camundongos selvagens (wild-type) tratados com $\mathrm{N}^{\mathrm{G}}$-monometil-L-arginina (L-NMMA, $40 \mathrm{mg} / \mathrm{kg}$; ini- bidor não-seletivo da NOS) ou aminoguanidina (AG, $10 \mathrm{mg} / \mathrm{kg}$; inibidor preferencial da iNOS) e em camundongos deficientes no gene da iNOS (iNOS knockout - iNOS-KO). A tolerância ao LPS foi induzida por meio de três injeções intraperitoneais (i.p.) consecutivas de LPS $(100 \mu \mathrm{g} / \mathrm{kg})$, em intervalo de 24 horas. Nos camundongos selvagens, foi observada redução significante da resposta febril às administrações repetidas de LPS. O tratamento com L-NMMA e AG aumentou marcadamente a resposta febril ao LPS nestes camundongos tolerantes. Além disto, camundongos iNOS-KO tratados repetidamente com LPS não se tornaram tolerantes ao LPS. Esses dados corroboram a hipótese de que o NO modula a tolerância ao LPS em camundongos e que a isoforma iNOS está envolvida na síntese do NO durante a tolerância ao LPS. 


\section{FUNÇÕES BIOLÓGICAS DA OLFAÇÃO NO SAPO BUFO PARACNEMIS}

\section{Fabiana Luca Alves}

Orientadora: Profa. Dra. Anette Hoffmann

Dissertação de Mestrado apresentada em 26/04/2005

Os sentidos químicos, incluindo a olfação evoluíram estreitamente vinculados ao comportamento alimentar, fornecendo pistas importantes quanto à qualidade e localização do alimento. Com relação ao olfato, há alguns indícios de seu envolvimento no comportamento de defesa, principalmente em peixes. Em espécies de vertebrados, geralmente outras modalidades de informações sensoriais, sobretudo visão, podem desempenhar papéis até mais importantes que a olfação e por isso pouca atenção tem sido dispensada a este sentido químico.

Trabalhos anteriores deste laboratório mostraram a participação de regiões subtectais do mesencéfalo de Bufo paracnemis na organização de diferentes respostas ligadas ao comportamento defensivo. Dentre as reações de defesa, evocadas pela ativação desta região, estão as respostas de imobilidade, e mais especificamente a imobilidade tônica. Ewert (1984) analisou a importância da informação visual no desencadeamento e modulação da resposta de captura de presa em sapos, mas pouca atenção foi dada ao papel exercido pela olfação. Além disso, sabe-se que projeções olfatórias secundárias alcançam um territó- rio extenso do telencéfalo nestes animais.

No presente trabalho foram estudadas as alterações comportamentais e neurovegetativas decorrentes da microinjeção de bicuculina (antagonista GABAérgico) e carbacol (agonista colinérgico) no bulbo olfatório, bem como os seus efeitos sobre a latência e a duração dos episódios de IT. Nossos resultados mostraram que a microinjeção de bicuculina, mas não de carbacol, induz respostas ligadas ao comportamento de captura de presa e defesa.

Ademais, foi observado um aumento dos movimentos oscilatórios do assoalho bucal induzida pela microinjeção de bicuculina. Este aumento acelera o influxo de ar pelas narinas maximizando a função olfatória. Apesar da intensa resposta ventilatória, os parâmetros cardiovasculares não sofreram alterações, mostrando a existência de uma ativação independente das regiões mais caudais que comandam ou modulam as ações neurovegetativas.

Observamos também que a administração de carbacol no bulbo olfatório induziu aumento na duração dos episódios de IT, enquanto que a microinjeção de bicuculina não provocou alteração nenhuma sobre esta resposta defensiva antipredatória. Estes resultados corroboram dados da literatura mostrando que o sistema colinérgico é o principal responsável na ativação da IT nos diferentes grupos de vertebrados.

\section{PARTICIPAÇÃO DO FATOR NUCLEAR KAPPA B E DE MAP (MITOGEN- ACTIVATED PROTEIN) QUINASES NA EVOLUÇÃO DA NEFRITE TÚBULO-IN- TERSTICIAL INDUZIDA PELA GENTAMICINA}

\section{Rildo Aparecido Volpini}

Orientadora: Profa. Dra. Terezila Machado Coimbra Tese de Doutorado apresentada em 27/04/2005

O evento adverso mais importante do tratamento com gentamicina é a necrose tubular aguda (NTA) com insuficiência renal aguda que atualmente atinge cerca de $20 \%$ dos pacientes. Animais tratados com gentamicina podem apresentar áreas residuais de fibrose no compartimento túbulo-intersticial do córtex renal. O objetivo deste estudo foi analisar a participação do NF-kB e das MAP quinases ERK, JNK e p38 na nefrite túbulo-intersticial induzida pela gentamicina e verificar a possível relação entre a expressão do NF-kB, MAP quinases e ED-1 (macrófagos/monócitos) com as alterações histológicas e funcionais.

Quarenta e sete ratas Wistar foram tratadas com injeções intramusculares de gentamicina $(40 \mathrm{mg}$ / $\mathrm{kg}$ ) duas vezes ao dia, durante nove dias e $49 \mathrm{com}$ gentamicina+PDTC (antioxidante e inibidor inespecífico do NF-kB). Os animais dos grupos controles receberam solução de $\mathrm{NaCl} 0,15 \mathrm{M}(\mathrm{n}=20)$ ou solução de $\mathrm{NaCl} 0,15 \mathrm{M}+\mathrm{PDTC}(\mathrm{n}=20)$. O PDTC foi administrado via intraperitoneal, na dose de $50 \mathrm{mg} / \mathrm{kg}$, duas vezes ao dia, durante 15 dias. Este tratamento foi iniciado um dia antes da primeira injeção de gentamicina ou salina. Foram coletadas amostras de sangue e urina 5 e 30 dias após a interrupção do tratamento com gentamicina ou salina e em seguida, os animais foram sacrificados e os rins removidos para análise histológica, imunohistoquímica e immunoblotting.

Os animais tratados com gentamicina apresentaram aumentos transitórios das concentrações plasmáticas de creatinina, das frações de excreção de 
sódio e potássio e da albuminúria e queda da osmolalidade urinária, detectados 5 dias após a interrupção do tratamento $(\mathrm{p}<0,001)$. Trinta dias após, esses parâmetros já haviam retornado aos valores próximos aos observados no grupo controle. O tratamento com PDTC atenuou o aumento da creatinina plasmática e da albuminúria observado no $5^{\circ}$ após a interrupção do tratamento com gentamicina $(\mathrm{p}<0,05)$.

Os resultados dos estudos de imunohistoquímica evidenciaram aumento das expressões de NF-kB, das MAP quinases (ERK, JNK e p38) e de ED-1 (macrófagos/monócitos) no córtex renal dos animais tratados com gentamicina. Foi verificado também aumento da expressão de NF-kB e da MAP quinase p38 nos estudos de immunoblotting. O tratamento com PDTC reduziu a expressão do NF-kB, das MAP quinases ERK e p38 e ED-1 nos animais sacrificados cinco dias após a interrupção do tratamento com gentamicina. Os resultados obtidos são mostrados na tabela:
Os estudos histológicos revelaram alterações características de NTA nos animais sacrificados cinco dias após a interrupção do tratamento com gentamicina e de nefropatia crônica (fibrose, dilatação e atrofia dos túbulos renais) nos animais sacrificados 30 dias após a interrupção do tratamento. Foi constatado também aumento da área intersticial relativa no córtex renal dos animais tratados com gentamicina $(\mathrm{p}<0,001)$. $\mathrm{O}$ tratamento com PDTC atenuou as alterações histológicas observadas nesses animais.

Concluindo, os resultados mostram que o aumento da expressão de NF-kB e macrófagos e as alterações da expressão das MAP quinases ERK, JNK e p38 podem estar contribuindo para a progressão da lesão renal para fibrose túbulo-intersticial em animais com NTA induzida pela gentamicina. A inibição da ativação destas vias pelo tratamento com PDTC atenuou a nefrite túbulo-intersticial induzida pela gentamicina.

\begin{tabular}{|c|c|c|c|c|c|}
\hline & Controle & Genta 5 d & G+PDTC 5d & Genta 30 d & G+PDTC 30d \\
\hline NF-kB & $0,89 \pm 0,08$ & $2,10 \pm 0,12 * * *$ & $1,26 \pm 0,06 * * *++$ & $1,58 \pm 0,11 * *$ & $1,35 \pm 0,05 *$ \\
\hline p-ERK & $0,47 \pm 0,03$ & $1,23 \pm 0,14 * * *$ & $0,57 \pm 0,05^{+++}$ & $0,74 \pm 0,06$ & $0,73 \pm 0,06$ \\
\hline p-JNK & $0,69 \pm 0,12$ & $1,49 \pm 0,10 * * *$ & $1,64 \pm 0,69 * * *$ & $1,57 \pm 0,07 * * *$ & $1,34 \pm 0,08 * * *$ \\
\hline p-p38+ & $50,0 \pm 2,65$ & $174,0 \pm 14,63 * * *$ & $87,3 \pm 7,38 *+++$ & $70,0 \pm 7,22$ & $80,0 \pm 2,83$ \\
\hline ED-1+ & $4,23 \pm 0,67$ & $45,34 \pm 6,10 * * *$ & $15,83 \pm 2,76 * * *+++$ & $18,25 \pm 2,05 * * *$ & $8,25 \pm 1,36^{\# \# \#}$ \\
\hline
\end{tabular}

Os resultados são expressos como média \pm EPM. NF-kB, p-ERK e p-JNK foram avaliados por escore. ED-1 + e p-p38 + foram avaliados pela contagem de células positivas por área de córtex renal $\left(0,245 \mathrm{~mm}^{2}\right.$ e $0,05 \mathrm{~mm}^{2}$ respectivamente).

${ }^{*} \mathrm{p}<0,05,{ }^{* *} \mathrm{p}<0,01 \mathrm{e} * * * \mathrm{p}<0,001$ (vs. Controle); ${ }^{++} \mathrm{p}<0,01 \mathrm{e}^{+++} \mathrm{p}<0,001$ (vs. Genta 5 dias); ${ }^{\# \# \#} \mathrm{p}<0,001$ (vs. Genta 30 dias).

$\mathrm{G}$ ou Genta, Gentamicina; 5d, 5 dias; 30d, 30 dias.

\section{PARTICIPAÇÃO DA VIA HEME-OXIGENASE (HO) NA DEFICIÊNCIA DE VA- SOPRESSINA (AVP) DURANTE O CHOQUE ENDOTOXÊMICO}

\section{Viviana Moreto}

Orientadora: Profa. Dra. Evelin Capellari Cárnio

Dissertação de Mestrado apresentada em 20/06/2005

O choque endotoxêmico é um quadro clínico caracterizado por queda acentuada na pressão arterial, a qual não responde a agentes vasopressores. $\mathrm{O}$ choque endotoxêmico é geralmente induzido pela administração de endototoxinas como o lipopolissacarídeo (LPS) de bactérias Gram-negativas. A indução de choque endotoxêmico em animais, pela administração sistêmica de LPS, leva a uma resposta bifásica na liberação de vasopressina (AVP), um hormônio peptídico, com ação vasoconstrictora. Observa-se um aumento transitório na concentração plasmática deste hormônio durante as duas primeiras horas, seguido por um retorno à concentração basal durante a quarta e sexta hora após a administração de LPS. O presente estudo teve como objetivo avaliar a participação da via heme-oxigenase (HO) sobre a liberação de AVP durante o choque endotoxêmico.

$\mathrm{O}$ choque endotoxêmico foi induzido em ratos machos Wistar pela administração intravenosa de LPS, que provocou um aumento da concentração plasmáti- 
ca de AVP, queda do volume urinário, queda da temperatura corpórea, queda da pressão arterial média (PAM) e aumento da frequiência cardíaca (FC). Após duas horas da administração de LPS houve um retorno aos valores basais da concentração plasmática de AVP, aumento da temperatura corpórea, e um aumento do volume urinário, porém a PAM continuou em queda e a FC continuou aumentada. Ao administrar- mos intracerebroventricularmente o ZnDPBG (inibidor inespecífico da HO) juntamente com o LPS foi observado um aumento da concentração plasmática de AVP e a queda da PAM foi amenizada.

Sendo assim, nossos resultados sugerem a participação inibitória da via HO sobre a liberação de AVP durante a endotoxemia experimental, com conseqüente recuperação dos valores de pressão arterial.

\section{GENÉTICA}

\section{ESTUDOS CITOGENÉTICO E MOLECULAR DE TUMORES HUMANOS DO SISTEMA NERVOSO}

\section{Juliana Oliveira}

Orientador: Profa. Dra. Cacilda Casartelli

Dissertação de Mestrado apresentada em 01/04/2005

O câncer é uma doença cuja gênese e progressão estão relacionadas com o acúmulo de alterações em genes que controlam direta ou indiretamente o ciclo celular. Os tumores do sistema nervoso representam $2 \%$ de todos os tipos de câncer. Embora a incidência dos tumores de sistema nervoso seja pequena, comparada com outras neoplasias, elas estão entre as mais graves malignidades humanas, pois afetam o órgão responsável pela coordenação e integração de todas as atividades orgânicas. Geneticamente analisando, os tipos de alterações cromossômicas mais freqüentemente encontradas em tumores de sistema nervoso são as perdas ou ganhos de cromossomos inteiros ou perdas de regiões cromossômicas específicas através de deleções e/ou translocações não balanceadas. Estas perdas de cromossomos e/ou regiões cromossômicas específicas sugerem que a perda da função de determinados genes, principalmente dos supressores de tumor, podem ser importantes na gênese e na evolução dos tumores do sistema nervoso. Com o emprego de técnicas de biologia molecular e investigação citogenética, o presente trabalho tem como objetivo identificar alterações que possam ser eventos críticos na gênese e na evolução de tumores do $\mathrm{SNC}$, gerando assim, mais conhecimentos a respeito dessas neoplasias. Vinte e um tumores cerebrais fo- ram analisados citogeneticamente; destes, 10 tumores foram classificados como astrocíticos de alto grau, 3 como astrocíticos de baixo grau, 2 oligodendrogliais e 6 meningiomas. Dentre os tumores de alto grau, as alterações mais freqüêntes foram monossomia dos cromossomos Y e 15, e trissomia do cromossomo 19. Um dos glioblastomas não apresentou alterações clonais. Em um dos casos, todas as células apresentaram as alterações estruturais $\mathrm{t}(4 ; 5)(\mathrm{q} 11 ; \mathrm{q} 11 \mathrm{q} 13)$ e del(5)(q11q13). Nos tumores de baixo grau, as alterações mais freqüêntes foram a monossomia dos cromossomos Y, 8, 21 e 22, sendo que um dos tumores não apresentou alterações clonais. Apenas um oligodendroglioma apresentou alterações clonais, as quais incluem -X, -1, -4, -6, -9, -12, -15, -17, -19, +20, -21, 22. Dois meningiomas não apresentaram alterações clonais; nos outros casos as alterações mais freqüêntes foram a monossomia dos cromossomos X e 14 e a trissomia do 21. A análise molecular do gene PTEN nas 50 amostras de tumores cerebrais estudados não revelou nenhuma alteração mutacional. Nossos resultados se assemelham à literatura em relação à ausência de alterações no gene PTEN em tumores benignos; no entanto, em relação aos glioblastomas, a literatura cita uma alta frequiência de alterações no PTEN, mas não encontramos nenhuma alteração nas doze amostras analisadas. Algum outro mecanismo, como por exemplo, metilação da região promotora, acetilação de histonas etc., poderia estar envolvido na inativação desse gene nesses tumores. 


\section{MARCADORES MOLECULARES E VARIABILIDADE GENÉTICA EM BÚFA- LOS DO BRASIL}

\author{
Maria do Socorro M. Albuquerque \\ Orientador: Profa Dra Eucleia Primo Betioli Contel \\ Tese de Doutorado apresentada em 03/05/2005
}

O conhecimento da variabilidade genética é de fundamental importância. para elaborar estratégia de conservação e melhoramento animal. Devido a uma redução no efetivo populacional, dois grupos genéticos de búfalos existentes no Brasil são considerados ameaçados de extinção e vêm sendo mantidos no Banco de Germoplasma Animal da Amazônia - BAGAM, na Ilha de Marajó, no Pará. Dentro deste contexto, foram caracterizados geneticamente os grupos Carabao e Baio, que estão sendo conservados, assim como os grupos Murrah, Jafarabadi e Mediterrâneo, considerados comerciais. Dois tipos de marcadores moleculares, RAPD e microssatélites, foram utilizados para analisar, respectivamente, 233 e 382 bubalinos amostrados em 12 rebanhos dos estados do Pará, Goiás, Distrito Federal, São Paulo e Rio Grande do Sul. O DNA genômico foi extraído a partir dos linfócitos.Um total de 98 marcadores RAPD foram gerados com bandas variando de $344 \mathrm{a} 2.036 \mathrm{pb}$ a partir da amplificação de 21 primers de 10 - mers. Para esses marcadores a análise de variância molecular (AMOVA) dos cinco grupos, estimou a variabilidade genética entre e dentro dos mesmos em $26,5 \%$ e $73,5 \%$, respecti- vamente, sugerindo uma divergência genética significativa $(\mathrm{P}<0,0001)$ entre eles. Para a genotipagem dos locos microssatélites utilizou-se sistemas multiplex e fluorescentes sendo a eletroforese realizada em um seqüenciador automático modelo ABI 3100. Com base nas freqüências alélicas para 13 locos microssatélites, foi possível caracterizar a diversidade dos bubalinos a partir dos seguintes resultados: foram detectados um total de 121 alelos, variando de quatro a treze por loco, com média igual a 9,31. As médias para o Conteúdo de Informação Polimórfica (PIC) e a Heterozigosidade esperada $\left(\mathrm{H}_{\mathrm{E}}\right)$ foram respectivamente, 0,624 e 0,656. A análise de variância molecular (AMOVA), a partir de dados com microssatélites, estimou a variabilidade genética entre e dentro dos grupos em 12,27\% e $87,73 \%$, respectivamente. Estes resultados confirmam uma divergência genética significativa $(\mathrm{P}<0,0001)$ já encontrada nas análises com RAPD. Portanto, a combinação dos resultados obtidos pelas duas metodologias, permite concluir que tanto os marcadores RAPD como os microssatélites podem ser usados com eficiência para a quantificação da variabilidade e diferenciação de grupamentos genéticos de búfalos no Brasil como também que os cinco grupos genéticos estudados podem ser considerados populações geneticamente distintas, reforçando a necessidade de conservação dos grupos Carabao e Baio.

\section{EPIGENÉTICA E SEXAGEM: PADRÃO DE METILAÇÃO DA REGIÃO MHM EM GALLUS GALLUS DOMESTICUS}

Lisandra Cristina Caetano da Silva

Orientadora: Profa Dra Éster Silveira Ramos

Dissertação de Mestrado apresentada em 16/05/2005

O mecanismo da determinação sexual em Aves é ainda desconhecido. Diferentemente dos mamíferos, os quais apresentam um sistema de cromossomos sexuais onde as fêmeas são XX e os machos XY, as aves caracterizam-se pelas fêmeas heterogaméticas (ZW) e machos ZZ. A questão principal é se o W é o determinante feminino, ou a dose dupla de Z é machodeterminante, ou ambos. A região hipermetilada no macho (MHM) no cromossomo $\mathrm{Z}$ foi recentemente descrita e em galos é intensamente metilada, enquanto em galinhas encontra-se hipometilada. Em nosso estudo, nós analisamos o DNA extraído de penas de 40 espécimes de Gallus gallus domesticus para verificar o padrão de metilação da região MHM através de PCR e da enzima de restrição HpaII. Os resultados foram comparados com a amplificação por PCR dos genes $C H D-Z$ e $C H D-W$ e com o fenótipo das aves. Todos os machos (20/40) apresentaram hipermetilação da região MHM e todas as fêmeas (20/ 40), hipometilação. Embora o real papel da região MHM na determinação sexual é ainda obscuro e o fenômeno da sua metilação no cromossomo $\mathrm{Z}$ seja diferente do impriting genômico em mamíferos, a re- 
gião poderia constituir-se em um marcador universal de sexagem de aves e estar envolvida na determinação sexual pela influência em processos transcricionais. Após pesquisa na literatura, foi constatado que este é o primeiro estudo a empregar a região MHM para sexagem de aves por PCR. Este poderia ser um bom modelo para a análise de outras espécies, em especial para programas de reprodução em cativeiro que envolvem o prévio conhecimento do sexo dos animais e estudos da determinação sexual em aves.

\section{INATIVAÇÃO DO CROMOSSOMO X E SÍNDROME DE ULLRICH-TURNER: ANÁLISE ATRAVÉS DO PADRÃO DE METILAÇÃO}

\section{Adriana Araujo}

Orientadora: Profa. Dra. Éster Silveira Ramos

Dissertação de Mestrado apresentada em 18/05/2005

A Síndrome de Ullrich-Turner (SUT) pode ser definida como a combinação de achados fenotípicos e a ausência total ou parcial de um dos cromossomos X, freqüentemente acompanhada de mosaicismo cromossômico. Devido à elevada taxa de abortos relacionada com a monossomia completa deste cromossomo, foi sugerida a hipótese de que a concepção de indivíduos 45,X viáveis só acontece quando existe uma outra linhagem de células em alguns órgãos críticos ou num período decisivo durante a embriogênese. Nos casos de alterações estruturais e mosaicismo críptico, as técnicas citogenéticas convencionais podem não ser efetivas, sendo indicada a avaliação molecular. Quarenta e duas pacientes foram selecionadas para este estudo (seis mosaicos com um cromossomo sexual anormal e 36 com cariótipo 45,X "puro"). Nessas pacientes, o DNA foi extraído de sangue periférico e avaliado através do ensaio de HUMARA. Todas as pacientes do primeiro grupo mostraram resultados positivos para a presença de dois cromossomos $\mathrm{X}$ e em $5 / 6$ foi observada a presença de inativação preferencial do cromossomo X. No segundo grupo, 9/36 casos apresentaram mosaicismo críptico e 5/36, inativação preferencial. A identificação laboratorial de um segundo cromossomo $\mathrm{X}$ e de seu padrão de inativação é importante para o manejo clínico e aconselhamento prognóstico das pacientes com SUT.

\section{DIVERSIDADE GENÉTICA DE POPULAÇÕES INDÍGENAS PATAXÓ DA BAHIA}

\section{Sandra Mara Bispo Sousa}

Orientador: Prof. Dr. Aguinaldo Luiz Simões

Tese de Doutorado apresentada em 24/05/2005

As freqüências alélicas de 19 loci (oito ligados ao cromossomo $\mathrm{Y}$, três ao cromossomo $\mathrm{X}$ e oito autossômicos) foram determinadas em seis comunidades Pataxó (Boca da Mata, Barra Velha, Águas Belas, Pires, Imbiriba e Coroa Vermelha) localizadas no extremo sul do Estado da Bahia. A partir delas foram estimados os graus de diversidade genética dentro e entre as comunidades, de mistura étnica em cada uma delas, e verificada a existência de alelos e/ou haplótipos exclusivos, supostamente oriundos das populações originais. As freqüências alélicas mostraram contribuição não só ameríndia, como também portuguesa e africana nas comunidades. Os loci do cromossomo $\mathrm{Y}$ e dos autossômicos indicaram valores significativos de diversidade interpopulacional. A diversidade intrapopulacional foi superior à encontrada em populações ameríndias da Amazônia. Valores menores seriam esperados devido ao pequeno tamanho efetivo populacional, entretanto este aumento pode ser justificado pela mistura étnica descrita historicamente e aqui corroborada. Os haplótipos mais freqüentes definidos pelos marcadores do $\mathrm{Y}$ e $\mathrm{X}$ foram, respectivamente, o haplótipo fundador Pataxó, também o mais freqüente em nativos americanos (T/-/13/12/23/10/ 14/13), e os haplótipos (7/3/7) e (7/3). As estimativas de mistura étnica baseadas nos STRs-Y mostraram uma maior contribuição ameríndia $(\sim 67 \%)$ em Barra Velha, portuguesa em Pires ( 75\%), e uma contribuição africana relativamente alta em Coroa Vermelha $(\sim 35 \%)$. Os loci ligados ao X mostraram uma discutível contribuição africana em Pires ( 91\%) e Coroa Vermelha ( $66 \%)$. É provável que estes marcadores sejam pouco informativos para estimativas de mistura e/ou conduzam a cálculos de estimativas enviesadas. Os STRs autossômicos detectaram uma contribuição ameríndia que variou de $27,12 \%$ em Pi- 
res a 70,90\% em Imbiriba. Em conjunto, esses dados corroboram a hipótese de que o indivíduo fundador masculino foi de origem predominantemente ameríndia e portuguesa, seguida da africana. É provável que a maior parte das linhagens femininas sejam ameríndias, o que só poderá ser confirmado com a análise do DNA mitocondrial. Em conclusão, a presença de determinados alelos/haplótipos marcadores ameríndios, em conjunto com os dados de diversidade e de mistura étnica, mostram uma grande diferenciação genética entre as comunidades, oposta ao esperado. Provavelmente as comunidades têm diferentes histórias de formação e contato com a sociedade envolvente, mas ainda preservam parte de sua constituição original. A grande proporção do componente genético de origem ameríndia salienta a importância destas comunidades no entendimento das origens da população tri-híbrida brasileira.

\section{ANÁLISE DE MUTAÇÕES E DA EXPRESSÃO DO GENE $C O X-2$ E SUA RELA- ÇÃO COM A CARCINOGÊNESE EM PACIENTES PORTADORES DE MELANO- MA E LESÕES DE PELE NÃO MELANOMA}

\section{Gilmara Ausechi Antonucci}

Orientador: Profa. Dra. Catarina Satie Takahashi

Tese de Doutorado apresentada em 30/05/2005

As radiações ultravioletas (UV) são entre os carcinógenos, o mais comum em nosso ambiente. Dados epidemiológicos apontam as radiações UV como o principal causador de câncer de pele no mundo, além de outros fatores, como dieta, hábito tabagista, idade, e predisposição genética. Dentre os tipos de câncer de pele está o melanoma, o qual é um tipo de câncer que tem origem nos melanócitos (células produtoras de melanina) e tem predominância em adultos brancos. Embora só represente 4\% dos tipos de câncer de pele, o melanoma é o mais grave devido à sua alta possibilidade de metástase. Pacientes com melanoma têm um prognóstico pobre devido a freqüente disseminação à distância da doença. Apesar do tamanho da lesão primária ser freqüentemente pequeno, é comum que muitos pacientes já tenham atingido a metástase no momento do diagnóstico.

Muitos são os genes envolvidos no desenvolvimento do melanoma. Os processos inflamatórios são muitas vezes precursores da carcinogênese. O gene COX-2 é um dos genes envolvido neste processo, que catalisa a síntese de prostaglandinas, as quais estão associadas às vias de promoção tumoral.

Em vista disto, os objetivos deste trabalho foram analisar mutações nos éxons 1, 2, 4 e 5 do gene COX-2 pela técnica de PCR-SSCP, bem como a associação destas mutações com a resposta ao tratamento deste tipo de câncer. Uma outra abordagem foi a análise da expressão gênica por meio da técnica de
RT-PCR semiquantitativa a fim de entendermos o comportamento deste gene nos diferentes estadios do tumor e em lesões de pele não-melanoma (controle).

Para tanto, foram analisadas mutações em amostras de 50 pacientes divididos segundo o estadio da doença, sendo eles portadores de melanoma primário, melanoma metastático, e com lesões de pele não-melanoma (controle). Por esta análise, 10 amostras apresentaram bandas de migração aberrante no gel de poliacrilamida para o éxon 1 . As amostras foram submetidas ao seqüenciamento automático, onde caracterizou-se uma mutação do tipo $\mathrm{T}>\mathrm{A}$, que não alterava a proteína, portanto definida como silenciosa. Nos indivíduos controles não observamos nenhum tipo de mutação, embora tenha sido observado bandas de migração aberrante durante a PCR-SSCP. Pela análise semiquantitativa da expressão gênica foi possível observar uma expressão homogênea de $C O X-2$ para as amostras de tecidos provenientes de lesões metastáticas, onde a expressão esteve presente até a última diluição do cDNA (1:64), sendo estatisticamente significativa quando comparamos os dados com as amostras provenientes do tecido e da margem de segurança do tumor $(\mathrm{p}<0,05)$.O fator idade teve influência sobre a expressão de $C O X-2$ quando comparamos os dois grupos de estudo. Com base nestes dados sugere-se que exista uma associação da expressão de COX-2 com o estadio do tumor.

Portanto a caracterização do comportamento deste gene em nível de mutações e expressão pode ser de valor clínico para o prognóstico e tratamento deste tipo de câncer, podendo indicar que estes pacientes possam ter uma melhor resposta a terapia com inibidores de $C O X-2$. 


\section{IDENTIFICAÇÃO DE PRODUTOS GÊNICOS (ESTS) DE CÉLULAS B CD19+ LO- CALIZADOS EM LOCI DE SUSCEPTIBILIDADE AO LÚPUS ERITEMATOSOS SISTÊMICO USANDO cDNA microarrays}

\section{Glauce Lunardeli Trevisan}

Orientador: Prof. Dr. Geraldo A. da Silva Passos Jr Tese de Doutorado apresentada em 03/06/2005

A etiopatogênese das doenças autoimunes é um dos principais assuntos ainda não resolvidos na imunologia. Embora o conhecimento tenha aumentado muito nos últimos anos, a origem e a natureza dos mecanismos básicos de auto-agressão ainda permanecem como pontos controversos.

Um dos protótipos de doenças autoimunes mais bem conhecidos ao nível clínico e laboratorial é o lúpus eritematoso sistêmico (LES). O LES é uma patologia sistêmica crônica, caracterizada por reações imunes e sintomas clínicos anormais.

Embora muito estudada, a etiopatogênese do lúpus ainda permanece um enigma que talvez só poderá ser resolvido após a definição da base genética molecular da doença. Por mais de 20 anos, muitos esforços têm sido feitos para a compreensão da genética do LES.

Doenças poligênicas humanas, como as doenças autoimunes, são candidatas ideais às análises genético-moleculares em larga-escala, tais como seqüenciamentos de "expressed sequences tags" (ESTs) e análises da expressão gênica pelo uso de $c D N A$ microarrays.

A identificação da fração do genoma funcional que é utilizada por cada tipo celular, tecido ou órgão durante o desenvolvimento e nas suas funções normais e patológicas (estudo do transcriptoma) proverá informações moleculares valiosas para o estudo da estrutura biológica e fisiologia celular. O desenvolvimento de tecnologias automatizadas e em larga escala para a determinação de seqüências de DNA forneceu as ferramentas para as descobertas de genes, utilizando o seqüenciamento parcial de clones de cDNA selecionados ao acaso gerando as ESTs.

A geração de ESTs é indispensável em qualquer projeto genoma de mamíferos, fornecendo um grupo sistemático de seqüências para a determinação completa do genoma, além de representar uma ligação direta com a genômica funcional.

Embora o esforço para suprir a lacuna de seqüências de linfócitos nos bancos de dados e a identificação de genes esteja sendo feita, muitos dos resultados se concentram em análises de sequiências oriun- das de células B normais ou de células B de linfomas. Entretanto, poucos dados de seqüências têm sido registrados no GenBank com relação a doenças autoimunes humanas.

A metodologia das ESTs abriu a perspectiva para uma investigação qualitativa e quantitativa da diversidade de expressão gênica no lúpus eritematoso sistêmico e assim, determinar a extensão de expressão restrita ou não à doença.

Nosso projeto de pesquisa teve por objetivo avaliar os níveis de expressão gênica diferencial de ESTs de linfócitos B CD19+ de pacientes com lúpus eritematoso sistêmico (LES), comparados com o mesmo tipo de célula de indivíduos normais.

Para tal, preparamos uma biblioteca de cDNA random primed a partir de leucócitos periféricos (biblioteca de ESTs) de pacientes com LES, de onde selecionamos 960 clones para a preparação de cDNA microarrays. Realizamos a análise do perfil da expressão gênica de sete pacientes com LES e seis indivíduos normais usando marcação radioativa de cDNA de linfócitos B e hibridações em cDNA microarrays de nylon. Os valores numéricos quantitativos foram analisados por meio de programas estatísticos específicos para análise de cDNA microarrays (SAM, Cluster e TreeView), os quais nos permitiram o agrupamento hierárquico tanto das amostras de pacientes e controles em grupos distintos, quanto o agrupamento dos genes diferencialmente expressos entre os dois grupos pesquisados.

Selecionamos 28 clones de cDNA que permitiram identificar seqüências diferencialmente expressas de células B CD19+ de pacientes com LES.

Estes clones foram então seqüenciados e a comparação das seqüências com as depositadas no banco de dados GenBank mostrou que várias são idênticas às seqüências ORESTES (ORF ESTs - FAPESP/ LICR-HCGP) como esperado, já que utilizamos random primers para gerar nossa biblioteca de cDNA.

Quando comparamos nossas seqüências com seqüências genômicas, pudemos sobrepô-las em regiões cromossômicas descritas anteriormente como candidatas a loci de susceptibilidade ao lúpus eritematoso sistêmico ou outras doenças autoimunes.

Nossos resultados mostraram a importância da preparação de uma biblioteca de cDNA a partir de células específicas da doença (ou fenômeno biológico) que 
se deseja estudar. Além disso, mostramos que é possível colhermos dados de expressão gênica diferencial, usando a tecnologia de cDNA microarray, sem que as seqüências dos clones de cDNA utilizados no preparo do microarray sejam previamente conhecidas.

Com o objetivo de estabelecermos uma estratégia altamente seletiva na identificação de genes diferencialmente expressos, decidimos seqüenciar $a$ posteriori somente os clones de cDNA "diferenciais" após as análises estatísticas dos dados de microarrays.

O êxito do sistema-modelo foi demonstrado pelo posicionamento das sequiências obtidas em vários loci de susceptibilidade a doenças autoimunes, incluindo o LES. Isto possibilitou uma importante associação entre a genética humana que emprega os estudos de "linkage" com esta estratégia de identificação de produtos gênicos, na forma de ESTs, oriundos de loci de susceptibilidade a doenças autoimunes.

\section{ESTUDO DA EXPRESSÃO PROTÉICA DA MATRIZ METALOPROTEINASE (MMP-1, -2, $-3, \quad-9$ E -14$)$ EM TUMORES DA FAMÍLIA EWING E MEDULOBLASTOMA DE CRIANÇAS E ADOLESCENTES}

\section{Elvis Cristian Cueva Mateo}

Orientador: Prof. Dr. Luiz Gonzaga Tone

Dissertação de Mestrado apresentada em 21/06/2005

As matriz metaloproteinases (MMPs) constituem uma família de endopeptidases dependentes de cálcio e zinco, que exercem atividades proteolíticas na matriz extracelular. Atualmente, a expressão elevada das MMPs é sugerida como uma característica de muitos tumores maligno. Os tumores da família Ewing (TFE) são tumores que acometem primariamente os ossos, mas também podem afetar as partes moles adjacentes e são comuns em crianças e adolescentes. Por outro lado, o meduloblastomas (MB) é o tumor pediátrico primário mais freqüente do sistema nervoso central (SNC) e se localiza preferencialmente no cerebelo. As alterações moleculares, tais como a presença da proteína quimérica EWS-FLI1 nos TFE e os oncogenes $C$-ERBB-2, MYCN, MYCC nos MB promovem de forma direta ou indireta a expressão elevada das MMPs. Este estudo se propôs analisar a expressão protéica da MMP-1, -2, -3, -9 e -14 em os TFE e MB por meio da técnica de Western Blotting, além de realizar a quantificação dos níveis de expressão por densitometria e correlacionar os resultados de expressão das MMPs com a sobrevida dos pacientes.
As MMPs apresentaram um padrão diferencial de expressão dependente do tipo de tumor. Nas 11 amostras de MB estudados, $5(45,4 \%)$ apresentaram expressão das 5 MMPs e $6(54,6 \%)$ expressaram pelo menos uma MMP. Para as 6 amostras dos TFE, em $4(66,6 \%)$ foi observada a expressão de MMP-2, -9 e -14 , e em duas amostras $(33,4 \%)$ foi detectada a expressão de pelo menos uma destas MMPs, sendo que em nenhuma das amostras dos TFE foi observada a expressão da MMP-1 e -3. O resultado de expressão comparativa nos dois tipos de tumores mostrou que a MMP-2 apresentou um nível maior de expressão nos MBs (p=0,12). As MMP-9 e MMP-14 apresentaram maiores níveis de expressão nos TFE ( $\mathrm{p}=0,26$ e $\mathrm{p}=0,06$, respectivamente). É as MMP-1 e MMP-3 foram detectadas somente nos MBs ( $\mathrm{p}=0,05$ e $\mathrm{p}=0,005$, respectivamente). Estes resultados indicam que expressão das diversas MMPs pode estar relacionada com uma via complexa de regulação dos genes destas metaloproteinases nos dois tumores. Finalmente não foi encontrada relação entre a sobrevida dos pacientes e a expressão das metaloproteinases. Desta forma, os resultados obtidos devem ser interpretados com cautela e, apenas aumentando o número de pacientes avaliados seria possível ter uma melhor idéia da relação existente entre a expressão das MMPs e o prognostico do paciente.

\section{DNA MITOCONDRIAL NA AMAZÔNIA BRASILEIRA: ESTRUTURA GENÉTI- CA REGIONAL E INFERÊNCIAS CONTINENTAIS}

Celso Teixeira Mendes Júnior

Orientador: Prof. Dr. Aguinaldo Luiz Simões

Tese de Doutorado apresentada em 30/06/2005
Sítios arqueológicos, polimorfismos genéticos clássicos e marcadores moleculares (estes em menor quantidade) foram empregados nos últimos anos para 
o desenvolvimento de modelos de povoamento e investigação de rotas migratórias percorridas pelos primeiros habitantes do continente sul-americano. Apesar destes esforços, muitas incertezas relacionadas aos movimentos populacionais realizados pelos ancestrais dos índios contemporâneos na América do Sul ainda permanecem. Com o objetivo de estudar a estrutura populacional dos indígenas da Amazônia e contribuir para o melhor entendimento do povoamento deste continente, polimorfismos que definem os haplogrupos fundadores do DNA mitocondrial nativo-americano foram analisados em 308 indígenas pertencentes a 16 aldeias de 7 tribos da região central da Amazônia. A posição central ocupada por estas tribos no continente sul-americano faz com que sejam relevantes nas tentativas de reconstrução dos movimentos populacionais sul-americanos. Nesta região, existe particular interesse pela estrutura genética da tribo Tikúna, inicialmente tida como enigmática por se preservar como uma das únicas grandes tribos pouco miscigenadas da Amazônia central, e do grupo linguiístico Pano, que embora se distribua por grande extensão territorial, apresenta homogeneidades étnica, lingüística e cultural notáveis, razão pela qual as populações (tribos) deste grupo são consideradas como parte de uma mesma tribo. Oito aldeias Tikúna e seis aldeias de quatro tribos Pano (Katukina, Kaxináwa, Marúbo e Yaminawa) fazem parte deste estudo. Os resultados indicam que constituem populações realmente pouco miscigenadas, sendo a mistura inter-étnica feminina praticamente desprezível $(0,32 \%)$. Foi encontrada heterogeneidade entre aldeias Tikúna, sendo observados dois grupos altamente homogêneos que dife- rem consideravelmente entre si. Em relação aos Pano, a homogeneidade lingüística e cultural deste grupo não se reflete em sua estrutura genética, visto que os níveis de heterogeneidade entre populações Pano são equivalentes ou até mesmo superiores aos observados entre populações de afiliação lingüística distintas. No geral, as mulheres indígenas da região central da Amazônia se apresentaram mais heterogêneas do que os homens, o que pode ser interpretado como maiores taxas migratórias femininas. Por meio de análises continentais foi observado que tanto a afiliação lingüística quanto a geografia exercem forte influência no padrão de variabilidade genética nas Américas. Quando apenas populações ameríndias são consideradas, a heterogeneidade é maior entre populações sul-americanas do que norte-americanas, o que estaria relacionado com maior atuação da deriva genética neste continente. Os dados corroboram a hipótese de que uma onda migratória principal seria responsável pelo povoamento das Américas. Ao longo deste movimento migratório, múltiplos efeitos do fundador teriam ocorrido até alcançar a América do Sul. Ao entrar na América do Sul, tal onda teria assumido rotas distintas direcionadas ao norte (acompanhando a costa Atlântica em direção ao leste do continente), ao sul (acompanhando a costa do Oceano Pacífico) e, possivelmente, em direção ao centro da Amazônia. Visto que as principais rotas migratórias foram necessariamente percorridas por membros de ambos os sexos, a análise de marcadores patrilineares seria pertinente para se testar esta rota em direção ao centro da Amazônia, bem como as duas rotas clássicas anteriormente propostas e aqui corroboradas.

\section{EFEITOS GENÉTICOS TARDIOS DAS TERAPIAS ANTICÂNCER DETECTADAS PELA ANÁLISE DE FUSÕES GÊNICAS EM PACIENTES CURADOS DE LEUCEMIA E LINFOMA NA INFÂNCIA}

\section{Marjori Leiva Camparoto}

Orientadora: Profa.Dra. Elza Tiemi Sakamoto Hojo

Tese de Doutorado apresentada em 30/06/2005

Os agentes físicos e químicos utilizados nas terapias anti-tumorais são considerados potentes agentes mutagênicos e/ou carcinogênicos e podem induzir a formação de rearranjos específicos em pacientes que foram submetidos à terapia, sendo esse efeito uma das causas de risco ao desenvolvimento de neoplasias secundárias.

O presente trabalho teve como objetivo geral avaliar os efeitos genéticos tardios das terapias anticâncer em pacientes pediátricos que sofreram remissão do tumor para LLA e LNH/LH, em amostras de sangue coletadas em tempos variáveis após o término da terapia, isto é, em remissão clínica completa (RCC). Nesse estudo, estão sendo apresentados os resultados obtidos por citogenética convencional para a análise das aberrações cromossômicas (ACs) e molecular por FISH para detecção das fusões gênicas $B C R / A B L 1$ e $I G H / M Y C$ e por PCR semi-quantitativa para a quantificação do gene híbrido TRGV/BJ resultante de uma inv(7). 
Para o grupo dos pacientes curados de LLA, as freqüências de ACs e de sinais extras para os genes $B C R$ e $A B L 1$ foram significativamente maiores comparadas ao grupo controle. As freqüências de fusão $B C R / A B L 1$ não foram aumentadas para os pacientes curados. A análise retrospectiva realizada em amostras de medula óssea de quatro pacientes LLA em fase de diagnóstico permitiu verificar as freqüências da fusão $B C R / A B L 1$ e de sinais extras para ambos os genes, antes de iniciarem o tratamento; entretanto, não se constatou nenhuma correlação com o tempo após o término da terapia, analisada para dois sub-grupos de pacientes com menor (13 a 60 meses) ou maior tempo (> 60 meses) de RCC.

A análise do gene híbrido TRGV/BJ mostrou diferenças significativas para os pacientes LLA em RCC comparado ao grupo controle. Para os pacientes com menor tempo (13 a 60 meses) e maior tempo (> 60 meses) em RCC foram obtidas diferenças significativas em relação ao grupo controle. A influência das terapias foi verificada quanto ao aumento das ACs e do gene híbrido $T R G V / B J$ nos dois sub-grupos de pacientes LLA submetidos à QT e à QT+RT. No caso dos sinais extras para os genes $B C R$ e $A B L 1$ um aumento significativo foi verificado nos pacientes submetidos somente à QT. Quanto ao risco de recidiva (alto e baixo), as freqüências de ACs e de sinais extras para os mesmos genes, para os dois sub-grupos foram aumentadas em relação ao grupo controle, mas não houve diferença entre os sub-grupos $\mathrm{AR}$ e BR.

Para o grupo dos pacientes curados de LNH/
$\mathrm{LH}$ as frequiências de sinais extras para os genes $B C R$ e $A B L 1$ foram aumentadas em relação ao grupo controle. Para três pacientes no diagnóstico (amostras do tecido tumoral), as frequiências da fusão $B C R / A B L 1 \mathrm{e}$ sinais extras de ambos os genes, antes de iniciarem o tratamento, não diferiram das obtidas após o término do tratamento. Para o rearranjo IGH/MYC e sinais extras para ambos os genes, a análise indicou um aumento estatisticamente significativo comparado ao grupo controle. O mesmo foi verificado nos resultados obtidos com os pacientes submetidos à QT e à QT+RT. Na análise retrospectiva realizada para quatro amostras de tumor (paciente LNH no diagnóstico), nenhum aumento foi verificado em relação aos dados obtidos para os pacientes curados.

Em suma, as análises para ACs totais, bem como a presença de rearranjos gênicos específicos, como as fusões $B C R / A B L 1, I G H / M Y C$ e o gene híbrido $T R G V / B J$ em pacientes em RCC previamente submetidos a terapias anticancer, confirmam as freqüências aumentadas desses rearranjos após exposição à QT e/ou RT, sendo que esses dados indicam um aumento da instabilidade genômica em conseqüência dos tratamentos empregados. Assim, essas informações são relevantes para a avaliação dos efeitos genéticos tardios e quanto à avaliação de risco ao desenvolvimento de neoplasias secundárias em crianças e adolescentes curados que apresentaram LLA ou LNH/LH na fase infantil, constituindo dados inéditos em face à literatura ainda escassa em termos da elucidação dos efeitos genéticos tardios da terapia antineoplásica.

\section{IMUNOLOGIA BÁSICA EAPLICADA}

\section{RESPOSTA INFLAMATÓRIA INDUZIDA POR SALIVA DE LUTZOMYIA LONGIPALPIS E SUA INFLUÊNCIA NA INFECÇÃO EXPERIMENTAL POR LEISHMANIA BRAZILIENSIS}

\section{Vanessa Carregaro Pereira}

Prof. Dr. João Santana da Silva

Dissertação de Mestrado apresentada em 20/04/2005

Estudos têm demonstrado que a saliva de Lutzomyia e Phlebotomus é importante tanto na transmissão quanto no estabelecimento da infecção por Leishmania. De outra forma, a pré-sensibilização com a saliva conferiu uma resposta protetora a esta infecção. No presente estudo investigamos o efeito inflamatório induzido pela saliva de Lutzomyia longipalpis e sua influência no curso da infecção por Leishmania braziliensis em animais diferentes linhagens. Verificamos que o sonicado de glândula salivar de Lutzomyia longipalpis (SGS) induziu a migração de leucócitos no local do inóculo e, essa migração pode estar relaci- 
onada com a produção de quimiocinas, uma vez que o SGS induziu a expressão de mRNA para IP-10, MIG, MIP- $1 \alpha$ e RANTES nos animais BALB/c e RANTES e IP-10 nos animais C57BL/6. O desafio com L. braziliensis na presença de SGS levou a um aumento da infecção, com presença de maiores números de parasitas presente na lesão. Esse aumento da infecção por SGS pode estar correlacionado com o aumento de células $\mathrm{CD}^{+}$que produzem IL-4 no local do inóculo. Paralelamente, animais pré-sensibilizados três vezes com SGS apresentaram um reduzido número de células inflamatórias, exceto $\mathrm{CD}^{+} \mathrm{CD}^{+}$, e aumento na porcentagem de células $\mathrm{CD}^{+}$produtoras de IFN- $\gamma$ e CD $11 b^{+}$produtoras de IL-12. Vimos também que a pré-sensibilização aumentou a expressão de mRNA para IP-10, MIP- $1 \alpha$ e MIP- $1 \beta$ nos animais BALB/c e IP-10 e MIG nos animais C57BL/6, todas as quais estão relacionadas com padrão de resposta Th1. Entretanto, em relação aos receptores, houve uma diminuição da expressão do mRNA, com exceção de CXCR3, e foi independente da linhagem do camundongo. Ainda, a pré-sensibilização levou a um efeito protetor dos animais desafiados com L. braziliensis. Estes não apresentaram lesão e foi detectado reduzidos números de parasitas na orelha, sugerindo então que o efeito protetor foi mediado inicialmente por células $\mathrm{CD}^{+}{ }^{+} \mathrm{CD}^{+}$e totalmente dependente de IFN- $\gamma$. Em conclusão, os resultados demonstram que o papel da saliva de Lutzomyia longipalpis na exacerbação ou proteção à infecção por Leishmania é dependente de fatores quimiotáticos induzidos por diferentes inóculos os quais ativam células no local do inóculo e, dependendo da citocina que estas produzem, levam ao perfil de susceptibilidade ou resistência à infecção.

\section{DETECÇÃO DE CITOMEGALOVIRUS EM PACIENTES COM RETOCOLITE ULCERATIVA IDIOPÁTICA E NEOPLASIA COLO-RETAL}

\section{Viviane Casagrande Mariguela}

Orientador: Prof. Dr. Luiz Tadeu Moraes Figueiredo Dissertação de Mestrado apresentada em 25/05/2005

Os citomegalovirus (CMV) são um gênero da família Herpesviridae, que pode estar associado a síndromes gastrintestinais. Neste trabalho, buscou-se uma possível associação de CMV com Retocolite Ulcerativa Idiopática (RCU) e Neoplasia Colo-Retal. Para isso, amostras de sangue e tecido entérico de 21 pacientes com RCU, 14 pacientes com neoplasia colo-retal e 12 pacientes-controle sem condições inflamatórias do intestino, foram submetidas a PCR utilizando primers que amplificam 296pb do gene da glicoproteína B de CMV. Uma nested-PCR foi realizada para confirmação dos resultados com primers que amplificam 100pb. Nas amostras negativas para CMV realizou-se PCR para $\beta$-globina para descartar resultados falso-negativos. Nas amostras de tecido entérico, além da PCR, realizou-se imunohistoquímica com anticorpos monoclonais contra antígenos específicos de CMV.
A positividade para CMV foi maior no sangue quando comparada à do tecido entérico nos 3 grupos de pacientes, o que sugere latência do vírus em leucócitos circulantes. Observou-se genoma de CMV em 76,1\% dos casos de RCU, 64,3\% dos com neoplasia coloretal e $66 \%$ dos pacientes-controle, reflexo da alta prevalência do vírus na população e não associado a RCU ou neoplasia colo-retal. No tecido entérico, observouse CMV em 57,1\% dos casos com RCU, 14,3\% dos com neoplasia colo-retal e 41,6\% dos pacientes-controle. Nos pacientes com RCU que utilizaram drogas imunossupressoras, $71,4 \%$ tinham CMV infectando o tecido entérico, enquanto isto ocorreu em $42,8 \%$ dos pacientes não-imunossuprimidos, sugerindo que seja uma infecção secundária associada à baixa imunidade. A PCR e a imunohistoquímica mostraram-se sensíveis e adequadas para detecção de CMV. Estudos com maior número de pacientes seriam necessários para confirmar definitivamente se este vírus ubíquo estaria associado a RCU. A infecção por CMV não se mostrou associada à neoplasia colo-retal.

\section{DETECÇÃO VIRAL POR MÉTODOS MOLECULARES EM AMOSTRAS LIQUÓRICAS DE PACIENTES COM INFECÇÃO DO SNC}

\section{Laura Patricia Mendoza Torres}

Orientador: Prof. Dr. Luiz Tadeu Moraes Figueiredo

Dissertação de Mestrado apresenta em 30/05/2005
Neste estudo foi realizado o diagnóstico laboratorial das infecções virais mais freqüentes que acometem o SNC utilizando métodos da reação em ca- 
deia pela polimerase (PCR). Estudou-se liquores de 200 pacientes apresentando sintomas clínicos de meningite, encefalite, meningoencefalite, polineurite e mielite. As amostras foram analisadas por MultiplexPCR (M-PCR) para Herpesviridae, RT-nested-PCR (RT-N-PCR) para Enterovirus, e Multiplex-RTnested-PCR (M-RT-N-PCR) para Alphavirus e Flavivirus. Genoma viral foi detectado em $43(23,34 \%)$ amostras de liquor incluindo, Enterovirus em 22/194 $(11,34 \%)$ amostras; CMV em 12/200 (6\%) amostras; HSV-1 em 10/200 (5\%) amostras; VZV e EBV em $1 / 200(0,5 \%)$ amostra cada um. Também foram detectadas três co-infecções, uma de CMV e HSV-1 e duas de CMV e Enterovirus. Nenhuma das amostras foi positiva para Alphavirus e Flavivirus. Infecções virais do SNC foram detectadas em pacientes de todas as idades. Os Enterovirus foram detectados com maior freqüência. Infecções do SNC por estes vírus geralmente são subestimadas em adultos. A infecção por CMV predominou em pacientes infectados pelo HIV. Também 5 pacientes infectados com HIV e que tiveram Herpesviridae detectado em liquor foram a óbito. Observou-se maior freqüência de encefalite e meningoencefalite entre pacientes que tiveram HSV1 detectado em liquor (8/10 amostras, 80\%). Parâmetros liquóricos (citologia, teores de proteína e glicose), mostraram-se normais em algumas amostras que tiveram vírus detectados em SNC permitindo criticar a validade absoluta destes parâmetros quando analisados isoladamente em casos de infecção virótica do SNC. Os métodos de M-PCR, RT-N-PCR e M-RTN-PCR permitiram o diagnóstico rápido e confiável sendo recomendável a implantação dos mesmos para uso rotineiro no diagnóstico de infecções virais do SNC.

\section{INTERLEUCINA-7 REGULA NEGATIVAMENTE O DESENVOLVIMENTO DE CÉ- LULAS T E A EXPRESSÃO GÊNICA DE TIMOS ADULTOS EM CULTURA (ATOC)}

\section{Marina Oliveira e Paula}

Orientador: Prof. Dr. Geraldo A. da Silva Passos Jr

Dissertação de Mestrado apresentada em 10/06/2005

A maturação dos linfócitos T a partir de progenitores comprometidos passa por estágios definidos e é principalmente associada à recombinação samática e expressão de genes de receptores de células T (TR), proliferação celular, seleção induzida por antígeno e aquisição de fenótipos maduros e de capacidades funcionais. A estrutura tridimensional do timo, bem como a ação das citocinas, é de fundamental importância durante esse processo de maturação dos timócitos. Ao contrário das culturas dispersas, a técnica de ATOC (Adult Thymus Organ Culture) preserva toda a arquitetura do timo e representa fielmente o microambiente onde ocorre a diferenciação de células T. Por esse motivo, esta técnica é tida como o modelo experimental ideal para o estudo da ação das citocinas nas células tímicas. A interleucina 7 tem papel fundamental durante todo o processo de maturação dos timócitos no timo, como garantir sua sobrevivência e estimular a recombinação $\mathrm{V}(\mathrm{D}) \mathrm{J}$ dos TR em timos de feto quando se inicia a maturação de linfócitos T. No timo maduro, a IL-7 tem efeito contrário, inibindo o desenvolvimento de células T. O objetivo principal deste projeto foi avaliar o efeito do tratamento in vitro com IL-7 em células de timo de camundongos adultos (adult thymus organ culture, ATOC). A quantificação da recombinação $\mathrm{V}(\mathrm{D}) \mathrm{J}$ entre os segmentos TRVB8.1 e DB2.1 foi utilizada para avaliarmos se a IL-7 exógena poderia modular a maturação dos linfócitos T em ATOC. Nossos resultados mostraram que o timo adulto em cultura abriga linfócitos $\mathrm{T}$ com o segmento recombinado, mas a IL-7 exógena não incrementou a frequência da recombinação $\mathrm{V}(\mathrm{D}) \mathrm{J}$ e, portanto, não estimulou a maturação destas células no timo adulto. Ao contrário, observamos redução do segmento TRVB8.1 recombinado. Na realidade, existem evidências de que a IL-7 exerce efeito regulatório negativo no desenvolvimento progressivo de células T maduras. Com o intuito de avaliarmos então o efeito desta citocina sobre a expressão gênica de ATOC, utilizamos a tecnologia de cDNA microarrays, incluindo programas de bioinformática, como SAM (Significance Analysis of microarrays) e Cluster \& TreeView, para análise dos dados. Desta vez, foi possível mostrar que a IL-7 exógena em ATOC exerceu efeito regulatório negativo sobre a expressão de vários genes, ou seja, inibiu a expressão gênica. Dentre estes genes, salientamos Lck, Mapkapk2, Myb, Stat-1, Ubex 1, Ube2r2, Ccl11, CD97, G3bp, Hspa1a, dentre outros, os quais estão envolvidos em processos celulares essenciais como metabolismo, resposta a estímulos, processos fisiológicos celulares, comunicação 
celular, ciclo celular e apoptose. Nossos resultados mostraram que o sistema modelo de ATOC, ensaio de recombinação $\mathrm{V}(\mathrm{D}) \mathrm{J}$ de TR e análise da expressão gênica por microarrays foi adequado para entendermos melhor as bases genético-moleculares do efeito regulatório negativo de IL-7 no timo adulto.

\section{INTERFERÊNCIA DA GALECTINA-3 NO CURSO DA INFECÇÃO POR PARACOCCIDIOIDES BRASILIENSIS}

\section{Luciana Pereira Ruas}

Orientadora: Profa. Dra. Maria Cristina R.A. Barreira

Dissertação de Mestrado apresentada em 16/06/2005

Galectina-3 é proteína membro de uma família de lectinas animais ligante de $\beta$-galactosídeos, cuja atividade pró-inflamatória é conhecida. A expressão de galectina-3 por células do sistema imunitário, seu papel modulador da adesão célula-matriz extracelular, bem como de atrair macrófagos e monócitos fazem desta lectina candidata a reguladora da resposta inflamatória e imune. Os poucos estudos sobre galectina3 e resposta imunitária e/ou inflamatória foram realizados in vitro. O papel dessa lectina in vivo, em processos patológicos e fisiológicos, é pouco estudado.

Durante a infecção por Paracoccidioides brasiliensis, a imunidade celular corresponde ao principal mecanismo de defesa do hospedeiro. Células fagocíticas ativadas são fungicidas e leveduras que escapam da destruição suscitam resposta inflamatória granulomatosa. A formação de granulomas compactos colabora para a contenção do fungo e evita sua disseminação. $\mathrm{O}$ desencadeamento de uma resposta imune celular adequada, caracterizada pela produção de citocinas de padrão Th1 e formação de granulomas compactos é protetora na infecção por $P$. brasiliensis. Tal quadro nos motivou a investigar um possível papel para a galectina-3 no curso da paracoccidioidomicose experimental.

Inicialmente investigamos se a formação de granulomas nos pulmões de animais $\mathrm{C} 57 \mathrm{~B} 1 / 6$ relacionava-se com a maior expressão de galectina-3 pelas células inflamatórias. Estudo cinético mostrou haver associação direta entre o número de granulomas formados e detecção de galectina-3 no tecido. A partir do $15^{\circ}$ dia de infecção o pulmão dos animais apresentava acentuado número de granulomas e maior detecção de galectina-3. Assim, períodos subsequientes a 15 dias de infecção foram utilizados para a análise de alguns aspectos da doença em animais nocauteados do gene da galectina-3 (gal-3KO).

Camundongos gal-3KO infectados, em todo o período analisado, apresentaram menor resposta inflamatória no fígado, caracterizada pela formação de granulomas de menor tamanho e em menor número, em comparação aos formados no fígado do animal WT. A menor resposta inflamatória observada nos animais gal-3KO acompanhou-se de maior recuperação hepática de leveduras.

Avaliamos se a produção de citocinas também sofria interferência da ausência de galectina-3. Células esplênicas de camundongos gal-3KO infectados com P. brasiliensis secretaram níveis maiores de IL-12p40 do que células de camundongos selvagens, também infectados. Intrigantemente, a despeito da alta produção de IL-12, os níveis de IFN- $\gamma$ produzidos por células esplênicas de animais gal-3KO foram similares aos produzidos por células de WT infectados. Isso sugere que galectina-3, direta ou indiretamente, regule a produção de IFN- $\gamma$ por células T e NK, após a infecção.

A isotipagem de anticorpos séricos específicos para o fungo, em ambas as linhagens de camundongos, aos 30 dias de infecção, revelou que os animais gal-3KO apresentaram níveis significativamente maiores de IgG1 - que caracteriza um padrão Th2 de resposta imune - do que os detectados no soro de animais WT. Já em camundongos WT foram detectados níveis similares de IgG1 e IgG2b, denotando um padrão misto de resposta. Assim, a ausência de galectina3 parece ter inclinado um padrão misto para um padrão Th2 de resposta à infecção por $P$. brasiliensis.

Respaldados por recentes relatos de que a ausência de galectina-3 altera o padrão de resposta imune na asma e na toxoplasmose, concluimos que a deficiência de galectina-3 altera a resposta imunitária na paracoccidioidomicose, interferindo tanto na resposta inata (inflamatória) como a resposta adaptativa (produção de citocinas e anticorpos). Postulamos que a interferência exercida por galectina-3 varie em função do modelo de infecção e/ou inflamação utilizado e que maiores investimentos em estudos com animais deficientes para o gene da galectina-3 sejam necessários para melhor compreensão dos mecanismos que governam os padrões de resposta. 


\section{EFEITO DO ESTRESSE AGUDO PELO FRIO NA FAGOCITOSE DE TIMÓCITOS APOPTÓTICOS}

Renata Sesti Costa

Orientador: Dr. Bernardo Mantovani

Dissertação de Mestrado apresentada em 17/06/2005

Evidências mostram uma íntima relação entre o estresse e a ocorrência de variações na função imune tanto em modelos animais quanto em humanos, sendo sugerido em alguns trabalhos uma imunossupressão induzida pelo estresse, enquanto em outros foi revelado um aumento da função imune. Neste estudo, verificamos os efeitos do estresse e a ação dos principais hormônios envolvidos com esse mecanismo na fagocitose de células apoptóticas. Observamos que o estresse hiperagudo pelo frio $\left(-15^{\circ} \mathrm{C}\right.$ por 10 minutos) não alterou a capacidade fagocítica e a interação com timócitos apoptóticos nem de macrófagos peritoneais murinos não ativados, nem de macrófagos ativados com LPS. O estresse agudo $\left(4^{\circ} \mathrm{C}\right.$ por 4 horas) também não alterou a porcentagem de fagocitose e de interação de timócitos apoptóticos com macrófagos não ativados, porém, provocou uma diminuição na capacidade de fagocitose por macrófagos ativados com LPS. Este mesmo efeito foi observado em experimentos in vitro, nos quais corticosterona foi incubada com os macrófagos ativados em concentrações similares àquelas observadas no plasma após o estresse agudo pelo frio. Outros hormônios como epinefrina e norepinefrina não tiveram efeito in vitro, o que mostra que esta inibição da fagocitose induzida pelo estresse agudo foi devido, ao menos em parte, à corticosterona. Considerando as possíveis implicações fisiológicas desses resultados, podemos notar que a diminuição na fagocitose de células apoptóticas poderia resultar na sua progressão para estágios mais avançados de morte celular, o que deve contribuir para o desenvolvimento de inflamação e o aumentado risco de autoimunidade. $\mathrm{O}$ comportamento diferente entre macrófagos normais e ativados é discutido em relação ao possível efeito da tolerização ou "priming" dos linfócitos T no desenvolvimento de reações autoimunes.

\section{NEUROLOGIA}

\section{ESTUDO DA INTERAÇÃO FARMACOLÓGICA ENTRE MECANISMOS OPIOIDÉRGICOS E GABAérgicos NA MODULAÇÃO DO COMPORTAMENTO DE DEFESA ELICIADO POR ESTIMULAÇÃO ELÉTRICA E QUÍMICA DO CO- LÍCULO INFERIOR}

\section{Fabrício Calvo}

Orientador Prof. Dr. Norberto Cysne Coimbra

Dissertação de Mestrado apresentada em 29/04/2005

No presente trabalho foram determinados os efeitos da administração periférica e central de agonista opióide exógeno, morfina e de bloqueador opióide inespecífico naloxona, sobre o comportamento de defesa (congelamento e fuga) eliciado por estimulação elétrica e química (bloqueio GABAA) do colículo inferior. O efeito do pré-tratamento do tectum com microinjeções centrais de morfina e naloxona, seguido da microinjeção de bicuculina sobre o comportamento de defesa também foram determinados. O bloqueio inespecífico e a estimulação de receptores opióides no tectum foram comparados com o efeito da adminis- tração central de bicuculina nos sítios do colículo inferior que elaboram o comportamento defensivo, com o propósito de estudar a possível interação entre mecanismos opióides e GABAérgicos no controle de respostas comportamentais que têm sido associadas ao medo e ao pânico eliciados por estimulação do colículo inferior. O comportamento de defesa evocado pelo bloqueio de receptores GABAérgicos no tectum foi analisado quantitativamente, através do registro do número de cruzamentos, saltos, levantamentos e rotações, em cada minuto, durante 30 minutos, através do teste de campo aberto (open-field). Após a influência opióide na modulação das respostas defensivas eliciadas por estimulação do mesencéfalo dorsal haver sido comprovada, esse estudo foi estendido, com o propósito de investigar o envolvimento específico de receptores 
opióides do tipo \&\#61549;1 e \&\#61547; e de receptores GABAA, na modulação do comportamento de defesa. Para isso, foram determinados os efeitos da administração central de bloqueadores opióides específicos (naloxonazina e nor-binaltorfimina) sobre os limiares do comportamento de defesa eliciado pelo bloqueio GABAérgico no colículo inferior, através de microinjeções centrais desses bloqueadores no tectum como um pré-tratamento do mesencéfalo caudal, seguido da microinjeção de bicuculina. $\mathrm{O}$ aumento gradual da intensidade de estimulação elétrica do colículo inferior mostrou-se de caráter aversivo, pois os animais interromperam a atividade exploratória e produziram respostas caracteristicamente relacionadas ao medo, como o congelamento e a fuga. Após o pré-tratamento com morfina, por via intraperitoneal, os animais evocaram os mesmos comportamentos, com menor intensidade de estimulação elétrica, evidenciando uma característica pró-aversiva da estimulação inespecífica de receptores opióides. Por outro lado, após a injeção, por via intraperitonial, de naloxona, esses comportamentos defensivos foram evocados com maior intensidade de estimulação elétrica, o que sugere uma ação antiaversiva do bloqueio de receptores opióides no colículo inferior. Microinjeções de bicuculina no tectum de animais que receberam um pré-tratamento com morfina ou naloxona no mesmo substrato neural causou congelamento, seguido de reações de fuga explosiva, com maior ou menor intensidade, respectivamente, quando comparado com o grupo controle, pré-tratado com salina fisiológica. Esses dados corroboram aqueles previamente obtidos e sugerem uma ação antagônica entre vias opióides e GABAérgicas no substrato neural que organiza o comportamento de defesa no colículo inferior. Com o intuito de investigar o envolvimento de receptores \&\#956;1 e \&\#954; no controle opióide das reações defensivas organizadas no mesencéfalo dorsal, microinjeções de naloxonazina, de nor-binaltorfimina ou de seu veículo foram também realizadas no núcleo central ou pericentral do colículo inferior. A microinjeção central de naloxonazina causou um aumento no limiar de fuga induzido por estimulação elétrica da rede neuronial do colículo inferior envolvida com a organização e elaboração do comportamento de defesa. Esse efeito antiaversivo do bloqueio opióide $\mu 1$ no núcleo central e pericentral do colículo inferior foi corroborado por microinjeções locais de norbinaltorfimina. Dessa maneira, é possível inferir que mecanismos opioidérgicos estão envolvidos em respostas defensivas, pois a intensidade de estimulação elétrica do núcleo central do colículo inferior varia conforme a injeção sistêmica de morfina e naloxona, fármacos com propriedades pró-aversiva e antiaversiva, respectivamente. Além disso, o bloqueio farmacológico tônico com bicuculina, um antagonista GABAérgico, no núcleo central do colículo inferior também elicia respostas defensivas, caracterizadas pela ativação comportamental de fuga explosiva, geradas provavelmente pelo mesmo substrato neuronial modulado pelo sistema opióide. É possível que a atividade inibitória da via nigro-colicular sobre o teto mesencefálico encontrese também sob influência opioidérgica. Os presentes achados sugerem uma integração entre mecanismos GABAérgico e opioidérgico inibitórios, modulando as respostas defensivas que recrutam substratos neuroniais do colículo inferior responsivos a estímulos sonoros característicos, provavelmente de natureza aversiva. A integração de vias opióides e GABAérgicas no teto mesencefálico recruta receptores GABAA, opióides \&\#956;1 e opióides \&\#954; na elaboração do controle das diversas respostas comportamentais que têm sido associadas ao medo e ao pânico.

\section{ESTUDO LONGITUDINAL DO PADRÃO DE VASCULARIZAÇÃO DO ENDONEURO DO NERVO VAGO DE RATAS DA LINHAGEM WISTAR-KYOTO, EM DIFERENTES IDADES}

\section{Maria Cristina Lopes Schiavoni}

Orientadora: Profa. Dra. Valéria Paula Sassoli Fazan Dissertação de Mestrado apresentada em 06/05/2005

Nosso objetivo, com o presente estudo foi o de realizar uma descrição do padrão longitudinal de vascularização do endoneuro e de avaliar a existência de uma possível correlação entre a área fascicular e a área endoneural ocupada pelos vasos capilares no nervo vago de ratas da linhagem Wistar-Kyoto, em três diferentes fases da vida: 30, 180 e 360 dias de idade. Para tanto, três animais de cada grupo foram mortos e tiveram seus nervos vagos direitos preparados com técnicas histológicas de rotina para inclusão em resina epóxi. Secções transversais semifinas $(0,4 \mu \mathrm{m})$ seriadas, obtidas a cada $100 \mu \mathrm{m}$ de extensão longitudinal do nervo, até o esgotamento completo dos blocos, foram analisadas em nível de microscopia de luz. A morfometria 
dos fascículos e dos vasos capilares endoneurais, foi realizada com o auxílio de um sistema analisador de imagens computacional. A área fascicular média e a área média ocupada pelos capilares foram calculadas para cada segmento estudado (proximal, médio e distal) e comparadas entre segmentos (estudo longitudinal) e entre os grupos. A correlação entre a área fascicular total e a área endoneural ocupada pelos capilares foi estudada através de uma análise de regressão linear e do cálculo dos coeficientes de correlação. A porcentagem da área fascicular total ocupada pelos capilares endoneurais também foi calculada para cada segmento estudado e comparada entre segmentos e entre os grupos. Nossos resultados mostram que a área fascicular média de todos os segmentos estudados foi significativamente maior nos animais com 180 e 360 dias, comparados aos com 30 dias, em todos os segmentos estudados, acompanhando o ganho ponderal dos animais. Interessantemente, nos animais jovens (30 dias), houve uma tendência ao aumento dos valores dessa área no sentido longitudinal dos nervos, o que não foi observado nos animais mais velhos (180 e 360 dias). A área média dos capilares endoneurais aumentou no sentido longitudinal em todos os grupos estudados. Na comparação entre os grupos, houve uma estabilização da área fascicular média nos animais mais velhos, enquanto que houve uma diminuição da área média dos capilares endoneurais com o avançar da idade. A porcentagem da área fascicular total ocupa- da pelos capilares aumentou, no sentido longitudinal, nos animais jovens (30 dias) e tendeu à estabilidade nos animais mais velhos (180 e 360 dias), havendo nítida diminuição progressiva dessa porcentagem com o avançar da idade. O estudo dos diâmetros dos capilares endoneurais mostrou que esses diâmetros variam amplamente, sem nenhum padrão específico entre segmentos de um mesmo grupo os entre os diferentes grupos. Nossos resultados também mostraram a existência de uma correlação positiva fraca (coeficientes de correlação com valores muito baixos) entre a área fascicular total e a área endoneural ocupada pelos capilares. Esses dados sugerem que a entrada dos capilares no nervo não é acompanhada de um aumento proporcional na área do fascículo. Esse achado pode trazer implicações para aqueles estudos onde os autores realizam o cálculo da densidade das fibras, sem descontar a área do vaso endoneural. Isso porque não necessariamente o tamanho do fascículo acompanha a entrada de um vaso mais calibroso. Assim, na presença de vasos calibrosos e a não exclusão dessa área no cálculo da densidade das fibras, o resultado poderá ser subestimado, uma vez que a área do vaso estaria sendo computada como parte da área endoneural que contém fibras. Os dados de diminuição da porcentagem da área fascicular total ocupada pelos capilares com o avançar da idade podem sugerir que os nervos de animais mais velhos possam ser mais susceptíveis aos processos isquêmicos.

\section{ANATOMIA MICROSCÓPICA DO NERVO SURAL DE RATOS ESPONTANEA- MENTE HIPERTENSOS}

\section{Andréa Lurdes Rocha de Kalil}

Orientadora: Profa. Dra. Valéria Paula Sassoli Fazan Dissertação de Mestrado apresentada em 17/06/2005

Os ratos espontaneamente hipertensos (SHR) são considerados um dos melhores modelos da hipertensão essencial humana. Sabe-se que a hipertensão é o principal fator de risco para acidente vascular cerebral e demência vascular, por causar importantes mudanças cerebrovasculares, tornando o cérebro propenso a infartos, microaneurismas e isquemias. Entretanto, são raros os estudos sobre as alterações do sistema nervoso periférico (SNP), decorrentes da hipertensão. Embora haja alguns estudos sobre a morfologia de nervos em SHR, sugestivos de alterações decorrentes da hipertensão arterial, nenhuma descrição morfológica do nervo sural nessa linhagem de ra- tos encontra-se disponível. Nosso objetivo, com o presente trabalho foi realizar uma descrição detalhada, da morfologia e morfometria do nervo sural, de ratas da linhagem SHR com hipertensão bem estabelecida, e determinar se estes parâmetros mudam ao longo do nervo (estudo longitudinal) e/ou se existem diferenças entre os níveis correspondentes dos lados direito e esquerdo do mesmo animal (simetria lateral). Animais com 20 semanas de vida foram sacrificados e tiveram seus nervos surais preparados com técnicas histológicas de rotina para inclusão em resina. Secções transversais dos segmentos proximais e distais, dos nervos direito e esquerdo, foram analisadas em microscopia de luz e a morfometria dos fascículos foi realizada com o auxílio de um sistema analisador de imagens computacional. Nossos dados mostram que não há diferenças morfológicas e morfométricas importantes entre segmentos proximal e distal do mesmo lado bem 
como entre segmentos iguais em lados diferentes. Alguns parâmetros morfométricos apresentaram características sugestivas de imaturidade dos axônios ou de atrofia axonial. Outros trabalhos em andamento em nosso laboratório auxiliarão na investigação das ca- racterísticas morfológicas e morfométricas dos nervos de ratos SHR, somáticos e autonômicos, na tentativa de elucidar se os achados são decorrentes da hipertensão arterial desenvolvida por esses animais ou se são características intrínsecas dessa linhagem.

\section{ASPECTOS DESCRITIVOS E QUANTITATIVOS DA ANATOMIA MACROSCÓ- PICA E MICROSCÓPICA DO NERVO VESTÍBULO-COCLEAR DE COBAIAS}

Carlos Augusto Carvalho de Vasconcelos

Orientador: Prof. Dr. Amilton Antunes Barreira

Dissertação de Mestrado apresentada em 20/06/2005

O nervo vestíbulo-coclear da cobaia possui peculiaridades não encontradas em outros nervos periféricos. Não foram encontradas informações detalhadas sobre os aspectos morfométricos do VIII nervo craniano em cobaias adultas na literatura. A avaliação descritiva e quantitativa no presente estudo, evidencia informações que precedem o estudo das alterações que ocorrem em modelos experimentais de neuropatias do VIII nervo craniano e as doenças ou lesões que possam afetar o homem. Foram utilizadas 8 cobaias adultas, perfundidas com glutaraldeído a 2,5\% em tampão cacodilato de sódio $(0,025 \mathrm{M})$. Seus nervos direito e esquerdo ( $n=6,4$ nervos direito e 2 esquerdos) foram dissecados na região mediana do nervo e pós fixado com tetróxido de ósmio $\left(\mathrm{OsO}_{4}\right)$ a $1 \%$ e incluídos em resina epóxi Poly/Bed 812 ${ }^{\circledR}$. Os fragmentos foram cortados em secções transversais semifinas seriadas (6 nervos) com uma espessura de $0,5 \mu \mathrm{m}$ e corados com azul de toluidina para a microscopia de luz. Foram analisados os aspectos histológicos descritivos e topográficos do nervo vestíbulo-coclear em cobaias adultas, bem como os aspectos histométricos na parte mediana do nervo, no referente a densidade de fibras mielínicas, a distribuição dos diâmetros de tal tipo de fibras mielínicas, ao cálculo da razão $\mathrm{G}$ e o número de vasos sangüíneos encontrados dentro da área de cada nervo. O nervo coclear é envolvido pelo vestibular na porção inicial da junção de ambos. O conjunto, nervos coclear e vestibular e nervo vestíbu- lo-coclear têm a aparência bifurcada da letra Y, na horizontal com os ramos lateralizados, possuindo em média $5 \mathrm{~mm}$ de comprimento. É ricamente vascularizado e documenta uma completa interposição das fibras dos nervos coclear e vestibular, quando o fascículo do VIII nervo está completamente constituído. As suas fibras mielínicas dispõem-se paralelamente em seu sentido longitudinal e são circundadas por escasso tecido endoneural. Não foram evidencias fibras amielínicas no VIII nervo. A distribuição das fibras mielínicas no segmento mediano do VIII nervo craniano foi unimodal, havendo predomínio de fibras com 3,5 $\mathrm{mm}$ de diâmetro. O número de fibras foi de $5.390 \pm$ 1.504 fibras. $\mathrm{O}$ diâmetro das fibras variou de 1,5 a $6 \mu \mathrm{m}$ de diâmetro. Os axônios com $2,5 \mu \mathrm{m}$ de diâmetro foram predominantes quantitativamente: $6.757 \pm 1.922$ axônios. O diâmetro axonal variou entre $1 \mathrm{a} 4,5 \mathrm{~mm}$. A densidade média das fibras do VIII nervo em seu segmento mediano foi de $41.474 \pm 4384$ fibras $/ \mathrm{mm}^{2}$. O diâmetro fascicular foi de $0,77 \pm 0,04$ $\mathrm{mm}$. A razão $\mathrm{G}$ varia de 0,2 a 0,9 . O maior número de fibras tem razão $\mathrm{G}$ de 0,7 e 0,6 , respectivamente, predominando as fibras com 0,7 . Os resultados descritos neste trabalho científico são originais, contendo alguns resultados inéditos e pouco estudados na literatura científica sobre a anatomia e morfometria do VIII nervo craniano em cobaia. O nervo vestíbulo-coclear da cobaia é um nervo sensitivo aferente especial, e bem diferente em sua anátomo-fisiologia de todos os outros nervos sensitivos e motores encontrados nos mamíferos. A cobaia adulta é um excelente modelo experimental para o estudo do nervo vestíbulo-coclear, semelhantes aos de humanos.

\section{EFEITOS COMPORTAMENTAIS INDUZIDOS PELA ESTIMULAÇÃO MOTORA IMEDIATA APÓS ISQUEMIA CEREBRAL EM UM MODELO EXPERIMENTAL EM GERBILO}

Fernanda Lopes Buiatti de Araujo

Orientadora: Profa.Dra. Carolina A. R. Funayama

Tese de Doutorado apresentada em 23/06/2005
Por existir uma importante lacuna no conhecimento referente ao período em que se deve ter inicio a estimulação motora pós-lesão cerebral, este traba- 
lho teve como objetivo estipular o intervalo de tempo ideal entre a lesão e o início da reabilitação motora na reorganização do comportamento motor.

Foram utilizados roedores da espécie Meriones urgiculatus (gerbilo), pesando entre 50 e $80 \mathrm{~g}$. Para a realização do procedimento cirúrgico, cada animal anestesiado teve a artéria carótida externa comum esquerda exposta e ocluída por 10 minutos através de um fio de sutura e, posteriormente amarrada, provocando a oclusão definitiva da artéria. Para o grupo falso operado (Sham), a cirurgia foi interrompida antes da oclusão da artéria. Os animais foram divididos em 3 grupos, sendo que o terceiro grupo foi subdividido de acordo com o seguinte protocolo: I-Grupo Controle: Animais ingênuos, que não foram submetidos à cirurgia. II- Grupo Sham: Animais submetidos à cirurgia sem a produção de isquemia cerebral. IIIA- Grupo Isquemia não estimulado: Animais submetidos à cirurgia experimental que apresentaram sinais clínicos de isquemia. IIIB- Grupos Isquemia Estimulados $12,24,48$ e $72 \mathrm{~h}$ : animais com isquemia estabelecida e submetidos a estimulação motora forçada em diferentes momentos pós-isquêmicos. Para a estimulação motora, foi utilizada uma esteira motorizada para roedores (Isight, Ltda), ajustada a uma velocidade de 10m/ min, por um período de quinze minutos. No quarto dia pós-cirúrgico, os animais foram avaliados na arena circular de acrílico quanto ao comportamento de cruzamentos, levantamentos e auto-limpeza e no teste de Rota rod, a locomoção horizontal e o equilíbrio no cilindro em movimento. No final dos experimentos os animais receberam uma overdose de zoletil e seus cérebros foram retirados e congelados.
Os resultados obtidos no teste do campo aberto evidenciam uma diminuição estatisticamente significativa dos comportamentos de cruzamentos e levantamentos nos animais que sofreram isquemia, em relação ao grupo controle. Já a comparação dos animais dos grupos isquemia e estimulação motora revelaram um aumento da resposta motora estatisticamente significativa em relação aos comportamentos de cruzamentos e levantamentos para os grupos estimulados, porém para o comportamento de auto-limpeza somente o grupo isquemia estimulado $12 \mathrm{~h}$, apresentou aumento similar em relação ao grupo isquemia, que também mostrou performance superior aos demais grupos estimulados. Outro resultado encontrado em relação à esse grupo, foi a diminuição estatisticamente significativa do número de cruzamentos em relação aos demais grupos de animais com isquemia, estimulados.

Considerando o modelo do Rota rod, os animais estimulados permaneceram no cilindro em movimento por um tempo significativamente superior aos apresentados pelos animais do grupo isquemia.

Dessa maneira, este trabalho sugere que os animais submetidos à estimulação motora $(12 \mathrm{~h}, 24 \mathrm{~h}$, $48 \mathrm{~h}$ e $72 \mathrm{~h}$ ) apresentam desempenho motores superior ao serem comparados com aqueles submetidos à isquemia sem reabilitação motora, tanto no teste do campo aberto quanto no teste de Rota rod. Em relação aos tempos de início de estimulação motora, os animais precocemente reabilitados (grupo 12 horas) tiveram uma pior performance motora comportamental do que os animais dos demais grupos.

\section{OFTALMOLOGIA}

\section{SUBTIPOS DA ORBITOPATIA DE GRAVES. ANÁLISE TOMOGRÁFICA QUAN- TITATIVA E ASSOCIAÇÃO COM MARCADORES DE SUSCETIBILIDADE GENÉTICA}

\section{Patrícia Mitiko Santello Akaishi}

Orientador: Prof. Dr. Eduardo Antonio Donadi

Tese de Doutorado apresentada em: 08/04/2005

Este trabalho teve o objetivo de caracterizar os subtipos da orbitopatia de Graves em 101 pacientes com essa condição. Utilizando-se a tomografia computadorizada de órbitas para quantificar as áreas da musculatura extraocular e da gordura orbitária, foram identificados dois subtipos, com características clínicas e radiológicas distintas.

$\mathrm{O}$ aumento muscular foi superior ao grupo con- 
trole em 51 pacientes, que receberam a denominação de subtipo miogênico. $\mathrm{O}$ aumento da gordura foi superior ao grupo controle em todos os pacientes, no entanto, em 50 pacientes não houve aumento muscular. Esse grupo foi denominado subtipo não miogênico.

O subtipo miogênico exibe menor predisposição em relação ao sexo do que o subtipo não miogênico (relação feminino/masculino $=1,8: 1$ ) e ocorre em faixas etárias mais avançadas ( $5^{\mathrm{a}}$ e $6^{\mathrm{a}}$ décadas). As formas mais severas da OG, com neuropatia óptica e estrabismo restritivo, ocorrem somente nesse subtipo.
O subtipo sem aumento muscular predomina em mulheres (9:1), jovens ( $4^{\text {a }}$ década de vida) e não se associa a diplopia e neuropatia óptica.

A análise dos alelos HLA e dos microssatélites do TNF, mostrou que a suscetibilidade ao subtipo com aumento muscular foi relacionada ao HLA-DRB $1 * 16$ $(\mathrm{RR}=6,027)$ e $\mathrm{TNFb} 3(\mathrm{RR}=2,743)$. Embora os riscos relativos conferidos pelos alelos sejam relativamente baixos, esses resultados indicam que fatores imunogenéticos podem influenciar o desenvolvimento dos subtipos da OG.

\section{AVALIAÇÃO DA DINÂMICA DAS PÁLPEBRAS SUPERIOR E INFERIOR DURANTE MOVIMENTOS SACÁDICOS EM INDIVÍDUOS JOVENS E IDOSOS}

\section{Lívio Viana de Oliveira Leite}

Orientador: Prof. Dr. Antonio Augusto Velasco e Cruz

Tese de Doutorado apresentada em 15/04/2005

Objetivo: Comparar o efeito da idade na dinâmica dos movimentos sacádicos palpebrais superiores e inferiores e sua adequação ao modelo matemático do oscilador harmônico. Métodos: Uma câmera de vídeo acoplada a um computador doméstico foi utilizada para captar os movimentos sacádicos palpebrais verticais de 40 graus das pálpebras superior e inferior de 30 adultos jovens e 30 idoso. A análise dos movimentos foi realizada por meio de um software que capta o centro de massa em cada frame de uma marcação azul feita nas pálpebras. $\mathrm{O}$ modelo do oscilador harmônico amortecido foi utilizado para adequar as funções obtidas. Resultados: Todas as funções foram muito bem ajus- tadas pelo modelo do oscilador harmônico, com coeficientes da ordem de 0,99 . Foi possível medir a velocidade máxima, além das amplitudes máxima e final e a duração do movimento sacádico. Os movimentos ascendentes e descendentes dos adultos jovens foram mais rápidos do que os dos idosos na pálpebra superior. As amplitudes dos grupos foram similares na pálpebra superior, o que não foi verificado na pálpebra inferior, pois os idosos tiveram amplitudes maiores tanto nos movimentos ascendentes quanto nos descendentes. As velocidades não foram estatisticamente diferentes na pálpebra inferior. Conclusão: O modelo do oscilador harmônico amortecido ajusta com precisão os movimentos sacádicos das pálpebras superior e inferior de 40 graus. Os idosos apresentam movimentos de pálpebra superior mais lentos que os adultos jovens e movimentos mais amplos de pálpebra inferior.

\section{COMPARAÇÃO DA PRESSÃO INTRA-OCULAR ENTRE USUÁRIOS DE LATANOPROSTA 0,005\% OU BIMATOPROSTA 0,03\% APÓS A ADIÇÃO DE BRIMONIDINA $0,2 \%$}

\section{Djalma Antonio Abrão Júnior \\ Orientador: Prof. Dr. Argemiro Lauretti Filho \\ Dissertação de Mestrado apresentada em 28/04 /2005}

Objetivo: Avaliar o efeito hipotensor ocular da associação bimatoprosta $0,03 \%$ com brimonidina $0,2 \%$ em relação à associação da latanoprosta $0,005 \%$ com a brimonidina $0,2 \%$ em pacientes hipertensos ocula- res ou com glaucoma primário de ângulo aberto. Métodos: Neste estudo clínico randomizado foram avaliados vinte pacientes com hipertensão ocular ou glaucoma primário de ângulo aberto. A associação de bimatoprosta $0,03 \%$ com brimonidina $0,2 \%$ foi usada em um olho; e no olho contralateral a associação de latanoprosta $0,005 \%$ com brimonidina $0,2 \%$, após um período de desensibilização medicamentosa. Foram 
realizadas medidas pressóricas na pré-associação, 1 hora após a associação, 24 horas e 15 dias após. Resultados: A pressão intra-ocular inicial era semelhante em ambos os olhos $(15,6 \mathrm{mmHg} \pm 4,1)$, sem diferenças estatisticamente significantes. As duas associações mostraram bom efeito hipotensor em relação à pressão intra-ocular inicial, porém, a associação bimatoprosta/brimonidina mostrou-se mais eficaz (efeito hipotensor $16 \%$ maior). Conclusão: A associação bimatoprosta/brimonidina apresentou melhor efeito hipotensor ocular do que a associação latanoprosta/ brimonidina no período estudado.

\section{AVAliAÇÃO dA SÍNTESE PROTÉICA DA CÓRNEA DE COELHO PRESERVA- DA EM OPTISOL-GS ${ }^{\circledR}$}

\section{Giselle Oliveira Seixas}

Orientador: Prof. Dr. Sidney Júlio de Faria e Sousa

Dissertação de Mestrado apresentada em 16/05/2005

Objetivo: As córneas humanas são preservadas em meio de Optisol-GS ${ }^{\circledR}$ para transplante, no entanto pouco se sabe sobre o tempo máximo de preservação. Este estudo tem o objetivo de analisar o perfil de síntese e secreção de proteínas de córneas de coelho preservados por $0,4,7,14$ e 21 dias nesse meio e determinar o peso molecular aparente da proteína secretada pelo endotélio p20/30. Material e Métodos: Foram utilizadas 16 córneas de coelhos albinos, machos, dos quais duas para preservar por 10 dias, quatro por 4 dias, três por 7 dias, três por 14 dias e 4 por 21 dias. As córneas de coelho foram retiradas sob assepsia e armazenadas em meio de Optisol-GS ${ }^{\circledR}$ e mantidas a $4^{\circ} \mathrm{C}$. Foram retiradas do Optisol-GS ${ }^{\circledR}$ e incubadas em meio de cultura RPMI-1640 com prolina${ }^{3} \mathrm{H}, 50 \mu \mathrm{l}=50 \mu \mathrm{Ci}$, a $37^{\circ} \mathrm{C}$ em estufa com atmosfera enriquecida com $5 \%$ de $\mathrm{CO}_{2}$ por 20 horas. Após o tempo de cultura, os meios foram centrifugados e os sobrenadantes dialisados por 24 horas. Os precipitados (depósito do fundo do microfuge Eppendor ${ }^{\circledR}$ ) resultantes da centrifugação foram re-suspensos e processados para serem submetidos à técnica de western blot. Foram feitas dosagens de proteínas e medidas radiométricas dos meios de cultura dialisados, dos tecidos, dos meios e dos precipitados. O volume restante do meio de cultura foi iofilizados e re-suspenso em solução de amostra (AS) para eletroforese. As córneas cultivadas foram divididas em três partes: um dos fragmentos foi dissolvido em SDS 4\% para posterior dosagem de proteínas, o outro em AS, para eletroforese e o terceiro utilizado para análise histológica em parafina ou auto-radiografia. As amostras de tecidos e amostras processados, como descrito acima, foram submetidas a SDS-PAGE, seguido de fluorografia. Os géis foram expostos contra filme (Hyperfilm) e mantidos à $-80^{\circ} \mathrm{C}$ por períodos de tempo variáveis ao fim dos quais foram revelados. A partir das fluorografias colocar seus dados no programa IMAGE J, e determinar o peso aparente da proteína p20/30. Resultados: Na eletroforese e nos perfis fluorográficos foi possível ver a proteína secretada pelo endotélio que tem peso molecular entre 20 e $30 \mathrm{KDa}(\mathrm{p} 20 / 30)$ e determinamos seu peso aparente em $25 \mathrm{KDa}$. No western blot, não foi possível detectar a presença de citoceratina. A análise histológica reforça a hipótese de lise celular do epitélio corneano, uma vez que foi observada extensa desepitelização das córneas analisadas. As auto-radiografias mostraram incorporação da prolina- ${ }^{3} \mathrm{H}$ a todas as camadas da córnea, mas com diminuição desta ao longo do tempo de preservação. A AE dos meios apresentou queda progressiva, enquanto a dos tecidos aumentou com o tempo. A contagem endotelial apresentou aumento com maior o tempo de preservação. Conclusões: As fluorografias indicam que o endotélio continua secretando suas proteínas mesmo com maior tempo de preservação. A partir do western blot não podemos concluir quais são os componentes do precipitado. A desepitelização vista na histologia pode ser a responsável pela liberação de prolina $-{ }^{3} \mathrm{H}$ incorporada ao epitélio. A queda da incorporação de prolina - ${ }^{3} \mathrm{H}$ observada nas auto-radiografias sugere queda na síntese de proteínas pela córnea. A progressiva diminuição da $\mathrm{AE}$ nos meios de incubação conforme o aumento no tempo sugere que com o armazenamento haja uma perda progressiva da capacidade de síntese e secreção das células endoteliais. $\mathrm{O}$ aumento da AE do tecido pode refletir uma quebra da barreira epitelial e difusão de prolina ${ }^{3} \mathrm{H}$ incorporada às proteínas para o tecido. $\mathrm{O}$ aumento da contagem endotelial observada provavelmente é devido ao encurvamento das córneas e erro de leitura do microscópio eletrônico. 


\section{TROMBOFILIAS EM PACIENTES COM OCLUSÃO VENOSA DA RETINA}

Alessandro José Rodrigues Daré

Orientador: Prof. Dr. Rodrigo Jorge

Dissertação de Mestrado apresentada em 18/05/2005

Oclusão venosa da retina (OVR) e, tradicionalmente, considerada doença de indivíduos acima de 50 anos, e entre $50 \%$ e $70 \%$ dos pacientes apresentam hipertensão arterial, doença aterosclerótica cardiovascular e diabetes mellitus. Por atribuir a vasta maioria das oclusões vasculares retinianas a mudanças degenerativas da parede vascular, cotidianamente, nenhum tratamento efetivo tem sido encontrado para esta condição, limitando o papel do oftalmologista a prevenir complicações oculares futuras. Nas últimas décadas, substancial progresso tem sido alcançado na compreensão dos mecanismos fisiopatológicos envolvidos no tromboembolismo venoso (TEV). O mais significante avanço foi a confirmação do conceito de que condições de hipercoagulabilidade herdadas (trombofilias) estão presentes numa larga proporção de pacientes com trombose venosa e embolismo pulmonar (estimado em 60\%). A prevalência das trombofilias é bem conhecida em pacientes com trombose de membros inferiores, mas apenas pobremente estudada em pacientes com oclusões em sítios venosos não usuais, como o retiniano. Através do presente estudo determinamos a prevalência de trombofilias hereditárias e adquiridas entre os pacientes que se apresentaram com diagnóstico de oclusão de veia retiniana (OVR) de agosto de 2001 a janeiro de 2003, no serviço de Retina e Vítreo do Hospital das Clínicas de Ribeirão Preto - USP. Cinqüenta e três pacientes com diagnóstico de OVR aguda ( $<6$ meses) foram submetidos ao exame oftalmológico completo, incluindo: melhor acuidade visual corrigida, biomicroscopia, tonometria de aplanação, reflexos pupilares, oftalmos- copia indireta e retinografia fluorescente. A investigação para trombofilias, realizadas em amostras sangüíneas de todos pacientes, incluiu: anticorpo anticardiolipina (ACA), anticoagulante lúpico (aLUP), dosagem de fibrinogênio, deficiência dos anticoagulantes naturais (proteína S, proteína e antitrombina [AT]), fator V de Leiden, mutação 677 da MTHFR, e mutação G20210A da protrombina. Os resultados obtidos com pacientes com OVR foram comparados com banco de dados da população de nossa região. Diagnóstico de síndrome antifosfolípide (SAF) foi determinado em 34\% dos pacientes: 11 ACA positivos, 3 aLUP positivos e 4 pacientes tiveram tanto ACA quanto aLUP positivos, sendo extremamente significativo $(\mathrm{p}<0,0001)$ quando comparado com frequiência populacional $(4,8 \%)(\mathrm{OR}=5,15$; IC95\% 3,316-8,025). A prevalência de deficiência de proteína $S$ foi também, significativamente maior $(\mathrm{p}<0,0001)$ nos pacientes com OVR $(5,7 \%$ x $0,13 \%)(\mathrm{OR}=46,09$; IC95\% 12,738-166,79). Níveis elevados de fibrinogênio ( $\geq 400 \mathrm{md} / \mathrm{dl}$ ) também se mostrou significativamente maior $(37,7 \% \mathrm{x}$ $8,0 \%, \mathrm{p}<0,0001)$ nos pacientes com OVR quando comparado com dados da literatura $(\mathrm{OR}=6,93$; IC95\% 3,258-14,746). Mutação G20210A e fator Leiden V estiveram presentes em 3,8\% dos pacientes, ligeiramente acima dos controles $(1,3 \%$ e $2,6 \%$, respectivamente), não de forma significativa. Mutação da MTHFR esteve presente em 47,2\% dos casos, atestando seu polimorfismo com alta prevalência populacional ( $52 \%$ em caucasianos). Deficiência de proteína $\mathrm{C}$ e AT não foram encontradas em nenhum paciente. Neste estudo, SAF, deficiência de proteína S e hiperfibrinogenemia mostraram-se importantes fatores predisponentes à OVR, devendo ser investigados nos casos agudos que procuram atendimento oftalmológico.

\section{DISPASE ASSOCIADA À VITRECTOMIA MECÂNICA NA INDUÇÃO DO DES- COLAMENTO DO VÍTREO POSTERIOR EM SUÍNOS}

\section{Leonardo Bruno de Oliveira}

Orientador: Prof. Dr. Rodrigo Jorge

Tese de Doutorado apresentada em 18/05/2005

Objetivo: Avaliar o papel da dispase intravítrea associada à vitrectomia via pars plana na indução do descolamento de vítreo posterior em suínos.
Métodos: Vinte e quatro olhos de 24 animais foram randomizados para injeção intravítrea de dispase $(50 \& \# 956 ; \mathrm{g} / 0,05 \mathrm{~mL})$ ou solução salina balanceada (Grupo controle) imediatamente após a vitrectomia e antes da tentativa de indução do descolamento do vítreo cortical. Após um período de espera de 15 minutos, empregou-se a aspiração ativa subjacentemente 
ao nervo óptico, na tentativa mecânica de separação do vítreo posterior. No pós-operatório de $1^{\mathrm{a}}, 4^{\mathrm{a}}$ e $8^{\mathrm{a}}$ semanas, os animais foram avaliados clinicamnente, e examinados com eletroretinograma ( $4^{\mathrm{a}}$ e $8^{\mathrm{a}}$ semanas), seguidos de enucleação para análise com microscopia óptica, eletrônica de transmissão e varredura.

Resultados: Baseado nos achados intra-operatórios e análise pós-operatória com microscopia eletrônica de varredura, os olhos que receberam injeção intravítrea de dispase apresentaram maior incidência de descolamento do vítreo posterior comparados com os olhos que receberam injeção intravítrea de solução salina balanceada $(\mathrm{p}=0,029)$. As respostas eletroreti- nográficas obtidas na $4^{\mathrm{a}}$ e $8^{\mathrm{a}}$ semanas de pós-operatório foram semelhantes entre os grupos dispase e solução salina quando comparados com os olhos controles contralaterais de ambos os grupos. Exames clínicos, incluindo oftalmoscopia indireta, foram semelhantes no grupo controle, e em 11 de 12 animais do grupo dispase. A microscopia óptica, eletrônica de transmissão e varredura não demonstraram diferenças significativas entre os olhos tratados com dispase ou com solução salina balanceada.

Conclusão: Dispase mostrou-se útil como adjuvante à vitrectomia via pars plana facilitando a indução cirúrgica do vítreo posterior em suínos.

\section{ORTOPEDIA, TRAUMATOLOGIA E REABILITAÇÃO}

\section{AVALIAÇÃO EXPERIMENTAL DA RESISTÊNCIA DO ADESIVO DE FIBRINA APÓS REPARO DO NERVO ISQUIÁTICO DO RATO}

\section{Marcelo Tadashi Nishimura}

Orientador: Prof. Dr. Nilton Mazzer

Dissertação de Mestrado apresentada em 11/05/2005

A resistência do adesivo de fibrina (Tissucol®) foi testada em trabalho experimental no nervo isquiático do rato, comparativamente com a técnica microcirúrgica convencional, realizada com náilon 10-0. Os animais de experimentação foram submetidos à secção e à reparação imediata do nervo isquiático por meio do uso do adesivo de fibrina; no membro posterior contra-lateral foi realizada a sutura epineural. Os 2 grupos, o de sutura e o de adesivo, foram divididos em 4 subgrupos de acordo com o tempo em que foi realizado o ensaio mecânico de tração (Tempos $0,7^{\circ}, 14^{\circ} \mathrm{e}$ $28^{\circ}$ dia de pós-operatório). Cada subgrupo constituiuse de 12 ratos, com exceção do grupo II, em que houve a perda de um animal, totalizando 47 animais. $\mathrm{O}$ ensaio mecânico de tração foi realizado no próprio animal de experimentação. Após a exposição do nervo isquiático, desde a incisura isquiática até a fossa poplítea onde ocorre a trifurcação nervosa, foi reali- zada a tração a $1 \mathrm{~cm}$ proximal a reparação nervosa. As duas técnicas de anastomoses, através da sutura epineural e do adesivo de fibrina, foram submetidas a ensaios de tração numa Máquina Universal de Ensaio com uma célula de carga de 50N. Após uma pré-carga de $0,10 \mathrm{~N}$ foram realizados ensaios de tração no nervo isquiático a uma velocidade constante de $2 \mathrm{~mm} /$ minuto até a ruptura completa da reparação nervosa. Após a análise estatística dos resultados, observamos uma superioridade da resistência da sutura epineural sobre o adesivo de fibrina nos dias iniciais. Mas, a partir do $14^{\circ}$ dia pós-operatório, as resistências da reparação nervosa das duas técnicas se equipararam. Entre o $14^{\circ}$ e $28^{\circ}$ dia de pós-operatório não observamos diferença estatística da resistência à tração entre os grupos. Observamos que, apesar da menor resistência à tração nos dias iniciais, não ocorreu nenhum caso de perda da reparação com o uso do adesivo de fibrina. Concluímos que a utilização do adesivo de fibrina (Tissucol®) apresentou uma grande vantagem operacional sobre a técnica convencional de sutura, diminuindo o tempo operatório e mantendo ainda a estabilidade das reparações de nervos periféricos. 


\section{AVALIAÇÃO DO PICO DE TORQUE ISOMÉTRICO DOS EXTENSORES DO JOE- LHO EM INDIVÍDUOS COM LESÃO DO LIGAMENTO CRUZADO ANTERIOR}

\section{Adriano Prado Simão}

Orientadora: $\operatorname{Prof}^{\mathrm{a}} \operatorname{Dr}^{\mathrm{a}}$ Débora Bevilaqua Grossi

Dissertação de Mestrado apresentada em 17/05/2005

O propósito deste estudo consistiu em avaliar o pico de torque muscular isométrico em indivíduos com lesão do LCA comparados com a perna contralateral e com o membro dominante e não-dominante de indivíduos clinicamente saudáveis em diferentes ângulos de flexão do joelho. Foram selecionados quarenta voluntários (vinte voluntários com lesão do LCA e em vinte voluntários sem histórico de qualquer lesão prévia no joelho classificados como grupo controle) com idade entre 18 e quarenta anos $(31.1 \pm 7.45)$, altura $(174 \pm 6.65)$, peso $(78 \pm 9.71)$, do sexo masculino, recrutados através de convite verbal. Os voluntários foram posteriormente subdivididos em quatro grupos: (GL) joelho com LCA lesado do grupo lesado ( $\mathrm{N}=20$ ), (GC) joelho contralateral do grupo lesado (N=20), (GD) joelho dominante do grupo controle $(\mathrm{N}=20)$ e (GND) joelho não-dominante do grupo controle $(\mathrm{N}=20)$. Os voluntários foram adequadamente posicionados e estabilizados em um dinamômetro isocinético e instruídos a realizar três contrações isométricas voluntárias máximas (CIVM), com intervalo de dois minutos nos ângulos de $30^{\circ}, 60^{\circ}$ e $90^{\circ}$ de flexão segundo uma or- dem aleatória. O maior valor de pico de torque isométrico obtido foi registrado. Foram realizadas análises estatísticas intergrupos através do método de análise de variância (ANOVA) com medidas repetidas e, se necessário, a técnica da formação de contrastes na análise dos dados. Foi adotado como nível de significância $\mathrm{p} \leq 0,05$. As análises estatísticas foram realizadas através de comparações inter e intragrupos e com a utilização de uma média representativa de cada grupo. Os dados revelaram somente uma diferença estatisticamente significativa entre o GL vs. GC ( $p<0.001)$. As demais comparações entre GL vs. GD, GL vs. GND, GC vs. GD, GC vs. GND e GD vs. GND, não apresentaram diferenças estatisticamente significativas $(\mathrm{p}=0.16,0.35,0.30,0.12$ e 0.15 , respectivamente). Na avaliação da diferença do pico de torque isométrico entre os ângulos, todas as comparações apresentaram um menor valor de PT isométrico no ângulo de 30 graus $(\mathrm{p}<0.001)$. Porém, os valores de PT isométrico a 60 e 90 graus foram similares. O membro contralateral parece ser a melhor opção para prover dados normativos de força muscular em indivíduos com ruptura do LCA. Visto que os ângulos de 60 e 90 graus de flexão do joelho produziram valores similares de pico de torque isométrico, então a escolha dependerá das condições experimentais e clínicas dos pacientes.

\section{INFLUÊNCIA DA DESPERIOSTIZAÇÃO EM FRATURAS COMINUTIVAS DA TÍBIA DE CARNEIROS TRATADOS COM PLACA EM PONTE}

\section{Sandro Marcílio Pereira Gomes}

Orientador: Prof. Dr. Cleber Antonio Jansen Paccola

Tese de Doutorado apresentada em25/05/2005

Nas últimas décadas, inúmeros trabalhos têm preconizado a não manipulação do foco de fratura, no tratamento das fraturas diafisárias cominutivas dos ossos longos, com o objetivo de preservar a vascularização periosteal remanescente. Dessa forma, surgiram novos dispositivos de osteossíntese e novas técnicas cirúrgicas enfatizando a não abordagem do foco, a fim de possibilitar consolidação mais rápida e menor número de complicações, como, por exemplo, infecção, retarde de consolidação ou pseudoartrose. O objetivo deste trabalho foi avaliar se a desperiostização prévia em fraturas cominutivas, produzidas experimentalmente em tíbias de carneiros, foi capaz de promover maior necrose dos fragmentos e de alterar o processo de consolidação óssea. Para isso, foram utilizados carneiros adultos apresentando uma fratura cominutiva de tíbia do tipo C3, da classificação AO/ASIF. As fraturas foram produzidas, experimentalmente, por intermédio de um dispositivo desenvolvido no Laboratório de Bioengenharia da Faculdade de Medicina de Ribeirão Preto da Universidade de São Paulo. A seguir, foram tratadas com placa em ponte. Doze animais foram incluídos, divididos em dois grupos (grupo desperiostizado $=\mathrm{D} ;$ com descolamento periosteal prévio do foco a ser fraturado e grupo não desperiostizado $=\mathrm{ND}$; sem descolamento periosteal prévio) e acompanhados por um período de doze semanas. Durante o seguimento clínico, foram realizadas radiografias com quatro, oito e doze semanas de pós-operatório. Foram feitos, também, estudos histológicos convencionais, com 
fluorescência óssea e com corante azul de metileno intra-arterial pós-mortem. Após análise comparativa entre os grupos, foram feitas as seguintes observações: todos os animais deambularam sem limitações e com apoio total do membro após quatro semanas de cirurgia. O estudo radiográfico não demonstrou diferenças estatísticas quanto ao tempo de consolidação e à presença de imagens radiodensas compatíveis com formação de calo ósseo. Na histologia convencional, a reincorporação dos fragmentos foi aparentemente mais evidente no grupo não desperiostizado. Apesar disso, tanto na análise histológica convencional quanto nos estudos com tetraciclina, não ocorreram diferenças qualitativas na formação do calo ósseo. O estudo com o azul de metileno demonstrou menor impregnação do corante nos fragmentos corticais do grupo desperiostizado. Isto pode representar maior necrose dos frag- mentos desse grupo. Em conclusão, a desperiostização prévia, como método de manipulação do foco de uma fratura cominutiva experimental, em tíbia de carneiro, não foi capaz de alterar o processo de reparação óssea, apesar de os fragmentos, no grupo desperiostizado, apresentarem-se, aparentemente, mais desvitalizados. Relevância Clínica: Dano ao suprimento vascular periosteal dos fragmentos, talvez não seja tão importante para a formação de calo ósseo, provavelmente devido à preservação da continuidade longitudinal do periósteo no presente experimento. $\mathrm{O}$ receio de aumentar a desvitalização óssea em uma fratura cominutiva pela abordagem direta, pode ser supérfluo. Fragmentos ósseos desvitalizados em fraturas expostas poderiam, talvez, ser armazenados após descontaminação e, reimplantados quando o foco da fratura estiver livre de infecção e de tecidos desvitalizados.

\section{RETALHO PEDICULADO EM ILHA: UM MODELO EXPERIMENTAL DE CON- GESTÃO VENOSA, UTILIZANDO A ORELHA DE COELHO}

Ana Patrícia Carvalho Araújo do Amaral

Orientador: Prof. Dr. Cláudio Henrique Barbieri

Dissertação de Mestrado apresentada em 27/06/2005

A dificuldade técnica básica na microcirurgia é a realização da anastomose de vasos de pequeno calibre, especialmente as veias. Mesmo quando o reparo venoso é possível, há um risco elevado de trombose venosa no período pós- operatório. A principal complicação observada nesses procedimentos é a insuficiência venosa, com conseqüente congestão venosa que, quando não tratada, pode ocasionar graus variáveis de necrose tecidual e comprometer o sucesso dos procedimentos microcirúrgicos. O objetivo dessa pesquisa foi desenvolver um modelo experimental de congestão venosa, para estudo desta complicação e de sua terapêutica.

Foram feitos um total de 42 retalhos pericôndriocutâneos, baseados no pedículo auricular central, medindo $3 \mathrm{~cm} \mathrm{X} 2 \mathrm{~cm}$, no dorso da orelha de 24 coelhos machos, da raça Nova Zelândia, albinos, com peso corporal variando entre $1945 \mathrm{~g}$ a $2655 \mathrm{~g}$, fornecidos pelo Biotério Central da Faculdade de Medicina de Ribeirão Preto - USP. Os retalhos constituíram 6 grupos experimentais, a saber: Grupo 1 (controle) com $n=12$, Grupo 2 (isquemia primária por congestão venosa, sem divisão do nervo) com $n=6$, Grupo 3 (isquemia primária por congestão venosa, com divisão do nervo) com $n=6$, Grupo 4 (isquemia secundária por congestão ve- nosa, durante 6 horas) com $n=6$, Grupo 5 (isquemia secundária por congestão venosa, durante 8 horas) com $n=6$, Grupo 6 (isquemia secundária por congestão venosa, durante 10 horas) com $n=6$.

Os retalhos foram monitorados clinicamente durante 7 dias. A quantidade de congestão venosa foi estimada através da medida da espessura das orelhas, na região central dos retalhos, bem como pesagem dos retalhos, realizadas no sétimo dia de pós-operatório. Os resultados obtidos foram comparados entre os diversos grupos, utilizando-se o teste $\mathrm{t}$ de Student, para amostras pareadas, e o teste de Análise de Variância (ANOVA), para amostras não pareadas.

O monitoramento clínico foi eficaz no diagnóstico da congestão venosa, sendo que os principais sinais clínicos foram: edema, coloração roxo-azulada do retalho e sangramento de cor escura pelas bordas da ferida. Com relação à quantidade de congestão venosa, diferenças entre o Grupo 1 (controle) e os demais grupos experimentais foram observadas, demonstrando que o modelo foi eficaz em produzir congestão venosa. Além disso, também foram detectadas diferenças entre os grupos 2 e 3, que mostraram a importante contribuição da vasa nervorum para a drenagem venosa. Nenhuma diferença foi observada entre os grupos 4 , 5 e 6 . Portanto, foi obtida uma verificação experimental não só da eficácia do modelo proposto, mas também da importância da divisão ou "clampeamento" do nervo no processo. 


\section{OTORRINOLARINGOLOGIA}

\section{PRODUÇÃO IN VITRO DA CITOCINA IFN- $\gamma$, TNF- $\alpha$, IL-6 E IL-10 NO CÂNCER DE LARINGE: INFLUÊNCIA DO TRATAMENTO CIRÚRGICO E DO BCG}

\author{
Luis Carlos Conti de Freitas \\ Orientador: Prof. Dr. Rui C. M. Mamede \\ Dissertação de Mestrado 28/04/2005
}

O entendimento do comportamento das citocinas na presença do câncer de laringe e dos efeitos da ressecção cirúrgica sobre o sistema imunológico do hospedeiro são fundamentais para esclarecimento da fisiopatologia tumoral nestas fases, bem como, para o planejamento de esquemas de imunoterapia. Com isso, o presente estudo objetivou determinar a proliferação de linfócitos cultivados sob estímulo de Con-A e BCG e quantificar as citocinas IFN- $\gamma$, TNF- $\alpha$, IL-6 e IL-10 em sobrenadante de cultura de células mononucleares de sangue periférico de pacientes portadores de câncer de laringe, antes da cirurgia (PRE-OP), no pósoperatório recente (POR $=112 \pm 25,68$ dias) e no pósoperatório tardio (POT $=236 \pm 18,1$ dias). Foram realizadas culturas de células não-aderentes e aderentes sem estímulo e estimuladas com Con-A e BCG, em linfócitos, e LPS e BCG, em macrófagos. Dezessete pacientes portadores de câncer de laringe foram incluídos no estudo. A linfoproliferação foi processada através da incorporação de $3^{\mathrm{H}}$-timidina nas culturas de células não-aderentes, e analisada através do índice de proliferação (IP). A quantificação das citocinas foi realizada através do teste de ELISA em sobrenadante das culturas de células mononucleares. Foi observada queda no IP no PRE-OP $(\mathrm{p}=0,006)$ e POT $(\mathrm{p}=0,03)$ em culturas estimuladas com Con-A em relação ao grupo controle. Em culturas não-estimuladas o nível de IFN- $\gamma$ apresentou queda no PRE-OP $(\mathrm{p}=0,003)$ e no POT $(\mathrm{p}=0,02)$ em relação ao grupo controle, enquanto a citocina TNF- $\alpha$ mostrou redução no POT $(\mathrm{p}=0,01)$ e tendência à queda também no PRE-OP ( $\mathrm{p}=0,08)$. Os níveis de IFN- $\gamma$, TNF- $\alpha$ e IL-6 mostraram-se elevados no POT de culturas estimuladas por Con-A e LPS em comparação com o PRE$\mathrm{OP}(\mathrm{p}=0,001 ; \mathrm{p}=0,01 ; \mathrm{p}=0,004$; respectivamente). Nas culturas estimuladas por BCG observou-se recuperação na produção das citocinas IFN- $\gamma$, TNF- $\alpha$, no PREOP e POT, compatíveis com os níveis do grupo controle. Assim, pode-se concluir que os pacientes portadores de câncer de laringe apresentam uma deficiência intrínseca do sistema do imunológico (queda do IP e deficiências na produção de IFN- $\gamma$ e TNF- $\alpha$ ). Entretanto, o BCG mostrou-se capaz de re-estabelecer a secreção de IFN- $\gamma$ e TNF- $\alpha$, quando adicionado às culturas de células mononucleares. Além disso, a ausência do tumor parece exercer uma função moduladora positiva na produção de citocinas, elevando a capacidade de produção de IFN- $\gamma$, TNF- $\alpha$ e IL-6, no período pós-operatório.

\section{ESTUDO HISTOLÓGICO E PESQUISA DO HELICOBACTER PYLORI NA LARINGE DE PACIENTES COM DOENÇA DO REFLUXO FARINGOLARÍNGEO, E A SUA CORRELAÇÃO COM O REFLUXO GASTROESOFÁGICO}

\section{João Carlos Todt Neto}

Orientador: Prof. Dr. Marcos Grellet

Dissertação de Mestrado apresentada em 29/04/2005

A doença do refluxo, seja ele gastroesofágico ou faringolaríngeo, tem como base o retorno patológico de agentes agressores, representados pelo ácido clorídrico pela pepsina, pelos sais biliares e pelas enzimas pancreáticas, ocasionando lesão dos órgãos expostos. A patologia decorre de quebra na barreira antirefluxo, do favorecimento de um fator anatômico, provavelmente no esfíncter esofagiano inferior (EEI), e de um mecanismo bioquímico nos receptores esofágicos e laríngeos. O refluxo faringolaríngeo (RFL) 
apresenta sintomas específicos - globus faríngeo, disfonia, pigarro e tosse, e sintomas comuns ao refluxo gastroesofágico (RGE), como azia e odinofagia. A associação entre patologias otorrinolaringológicas e a doença do refluxo já está bem definida na literatura.

Este estudo avaliou um grupo de trinta pacientes com queixas clínicas de RFL, que foram atendidos no Ambulatório de Otorrinolaringologia do Hospital São Lucas, situado em Aracaju -SE. A idade média foi de 41 anos. Utilizaram-se como critérios de inclusão: queixas sugestivas de RFL, tempo de duração dos sintomas maior que três semanas, presença de alguma lesão na laringe sugestiva do refluxo, a saber: hiperemia e edema da prega vocal e/ou das aritenóides; paquidermia, granuloma e úlcera da comissura posterior.

Recorreu-se à videonasolaringoscopia para o diagnóstico das lesões laríngeas e à videoesofagogas- troduodenoscopia para o exame do esôfago e do estômago e para a realização de biópsias, que possibilitariam determinar as características das lesões histológicas e a presença do Helicobacter pylori.

Os resultados obtidos mostraram que, em pacientes com RFL, a hiperemia nas aritenóides e/ou nas pregas vocais foi o achado mais freqüente, enquanto o globus faríngeo foi o sintoma mais referido. Quanto à associação do RFL com patologias gástricas, o exame endoscópico revelou prevalência de gastrite em $63 \%$ dos pacientes, e hérnia hiatal em $43 \%$. O estudo histológico comprovou um processo inflamatório na laringe $(83 \%)$, no esôfago (73\%) e no estômago $(63,4 \%)$ no grupo de pacientes com suspeita de RFL. Em relação ao Helicobacter pylori, foi positivo no estômago (36,7\%), na laringe e no esôfago; cada um $\operatorname{com} 33,4 \%$.

\section{MOVIMENTOS SACÁDICOS EM INDIVÍDUOS COM ALTERAÇÕES CEREBE-}

\section{LARES}

\section{Aloysio Augusto Tahan Neto}

Orientador: Prof. Dr. José Fernando Colafêmina

Dissertação de Mestrado apresentada em 02/05/2005

A pesquisa dos movimentos sacádicos é parte da bateria de testes otoneurológicos que, através da eletro-oculografia, servem para a asserção da oculomotricidade. Os sacádicos constituem os movimentos oculares mais rápidos, de tal maneira que o ponto de interesse é detectado no centro visual da retina. O cerebelo apresenta importantes conexões com o troncocerebral e estruturas talâmicas que possuem função na geração de sacádicos. Indivíduos com disfunções cerebelares, sejam elas degenerativas, familiares, congênitas ou por ablação de alguma porção do cerebelo, apresentam dismetria dos movimentos sacádicos, as quais podem mostrar diversos padrões ao teste, dependendo da localização topográfica da lesão cerebelar. No presente estudo foi realizada inicialmente uma revisão de literatura sobre o tópico, evidenciando estudos que mostram as relações entre o cerebelo e os movimentos sacádicos. Foram selecionados 11 indivíduos com patologias de cerebelo de diversas etiologia, com idade entre 16 e 53 anos. Um grupo controle com outros 27 voluntários com idade variando entre 16 e 50 anos foi também selecionado. Os pacientes dos dois grupos foram submetidos à pesquisa dos movimentos sacádicos (fixo e randomiza- do). O aparelho utilizado foi um eletronistagmógrafo computadorizado de 4 canais de fabricação americana da Micromedical Technologies, sendo as respostas arquivadas e, posteriormente comparadas. A comparação das respostas foi feita entre os grupos controle e o com patologia cerebelar. Foram analisados os parâmetros quantitativos (velocidade, latência e acurácia) das respostas e a morfologia dos registros nos grupos controle e patológico. Além disso, as variáveis sexo e idade também foram avaliadas, segundo os parâmetros quantitativos nos dois grupos. Não foram encontradas diferenças nos parâmetros quantitativos nos dois grupos (controle e patológico), tanto no teste fixo quanto no randomizado. Idade e sexo também não exerceram influência na velocidade, latência e acurácia entre os sujeitos dos dois grupos e de cada um dos grupos. A morfologia das respostas, porém, foi que apresentou profundas diferenças entre os dois grupos, sendo que o grupo com patologias cerebelares apresentou dismetrias sacádicas (hipermetrias e hipometrias), glíssades, sacádicos de correção e assimetrias nas respostas entre olhos direito e esquerdo. Conclui-se, a partir de tal fato, que o cerebelo possui importantes conexões neurais com o sistema sacádico e tem função na regulação da amplitude e da morfologia dos movimentos sacádicos dos olhos. Além disso, a eletronistagmografia, através da morfologia dos movimentos sacádicos, pode ser um importante meio para o diagnóstico precoce de distúrbios da função cerebelar. 


\section{ANÁLISE DOS MOVIMENTOS SACÁDICOS DE PACIENTES COM ORBITOPA- TIA DE GRAVES POR MEIO DE VIDEONISTAGMOGRAFIA}

\author{
Paulo Roberto Crespi \\ Orientadora: Profa. Dra. Maria Cristina L. Cury Féres \\ Dissertação de Mestrado apresentada em 11/05/2005
}

A Doença de Graves (DG), uma disfunção da Glândula tireóide, pode levar a alterações orbitárias, em virtude do processo inflamatório local, denominado Orbitopatia de Graves, a qual, como conseqüência, pode levar a restrições na movimentação ocular.

O movimentos sacádicos são movimentos oculares que buscam objetos para mantê-los fixados no campo visual.

O objetivo deste trabalho foi estudar as características dos movimentos sacádicos de uma população portadora de Orbitopatia de Graves, através de videonistagmografia, levando-se em conta a velocidade, latência e precisão dos movimentos, tanto na horizontal como na vertical, comparando-se com um grupo controle.

Detectou-se no grupo de pacientes controle uma tendência a maior velocidade dos sacádicos quando os olhos se movimentam para a direita. Essa diferença entre os dois lados não foi encontrada nos pacientes com DG.

Quando compararados os dois grupos, os pacientes com Orbitopatia de Graves mostraram maior velocidade dos sacádicos, tanto horizontais como verticais. Os achados sugerem que o controle cortical dos movimentos oculares, e sua complexa rede neuronal têm papel primordial no controle dos sacádicos, suplantando as alterações locais orbitárias.

\section{PATOLOGIA}

\section{PAPEL PATOGENÉTICO dOS MASTÓCITOS, MACRÓfAgOS, TGF- $\beta$ E MIOFIBROBLASTOS NA EVOLUÇÃO DA NEFRITE LÚPICA}

\section{Roberto Cuan Ravinal}

Orientador: Prof. Dr. Roberto Silva Costa

Tese de Doutorado apresentada em 14/04/2005

Foram revisados os prontuários clínicos e os relatórios de biópsias de 69 pacientes com diagnóstico de nefrite lúpica no Hospital das Clínicas da Faculdade de Medicina de Ribeirão Preto da Universidade de São Paulo (HC FMRP-USP) no período de 1987 a 2003. O objetivo deste trabalho foi avaliar o papel patogenético dos macrófagos, mastócitos, TGF- $\beta 1$ e miofibroblastos na nefrite lúpica. O tempo de seguimento dos pacientes com nefrite lúpica foi de 75,5 \pm 57,3 meses. A idade de apresentação clínica variou de 8 a 52 anos $(25,8 \pm 10,2$ meses $)$. Oito pacientes apre- sentaram nefrite lúpica Classe II, 15 nefrite lúpica Classe III, 29 nefrite lúpica Classe IV e 18 pacientes apresentaram nefrite lúpica Classe V. O sexo, a idade e a raça não tiveram relação com o curso clínico da nefrite lúpica $\mathrm{O}$ curso clínico desfavorável da nefrite lúpica esteve relacionado com a Classe IV, com o índice de atividade para a Classe IV, com a escassa expressão do PCNA glomerular para a Classe II e com o infiltrado de macrófagos no compartimento túbulo-intersticial da nefrite lúpica Classe V. O curso clínico da nefrite lúpica não está relacionado com a presença de mastócitos no compartimento túbulo-intersticial, com a expressão do TGF- $\beta 1$ e $\alpha$-Sm actina tanto no compartimento glomerular quanto no compartimento túbulo-intersticial. 


\section{EFEITOS DA ATIVIDADE FÍSICA EM MARCADORES BIOLÓGICOS DA CAR- CINOGÊNESE QUÍMICA DO CÓLON DE RATOS WISTAR}

\section{Marcelo Marcos Piva Demarzo}

Orientador: Prof. Dr. Sérgio Britto Garcia

Tese de Doutorado apresentada em 04/05/2005

Estudos epidemiológicos vêm demonstrando que quantidades apropriadas de atividade física regular estão associadas a significativa redução do risco para o desenvolvimento de câncer de cólon em até $40 \%$ entre os indivíduos mais fisicamente ativos. Por outro lado, tem sido observado que o exercício físico exaustivo aumenta a produção sistêmica de radicais livres, com concomitante aumento dos danos oxidativos ao DNA, além de deprimir a função imune global, eventos relacionados ao aumento do risco para o desenvolvimento de câncer. Relativamente, poucos estudos experimentais exploram essas relações, principalmente no que concerne ao exercício exaustivo e o câncer. A taxa de proliferação celular epitelial, os focos de criptas aberrantes (FCAs) e as criptas com acúmulo de beta-catenina $(\mathrm{CABC})$ têm sido marcadores biológicos (biomarcadores) usados para a identificação precoce de fatores que poderiam influenciar a carcinogênese colônica em ratos. Através da aplicação do carcinógeno químico 1,2dimetilhidrazina (DMH), logo após os protocolos de exercício, foram estudados quatro grupos principais de ratos previamente sedentários (grupo-controle, e três grupos submetidos, respectivamente, ao treinamento crônico de natação, à natação até a exaustão, e à natação até a exaustão após treinamento crônico), sendo sacrificados quinze dias após a injeção da DMH. Após análise histológica e imunohistoquímica, os biomarcadores estudados mostraram resultados coerentes nas diferentes situações experimentais aferidas. Foi observada uma diminuição estatisticamente significante da resposta hiperproliferativa, do número de FCAs e de CABC no grupo que realizou o treinamento crônico, enquanto o grupo submetido ao exercício exaustivo apresentou aumento estatisticamente significante dos parâmetros citados, quando comparados ao grupo-controle. No grupo submetido à associação dos dois protocolos de exercício, quando comparado ao grupo-controle, não houve alterações significantes nos biomarcadores de transformação neoplásica estudados. Nesse estudo experimental, o treinamento físico crônico teve efeito protetor contra o desenvolvimento dos biomarcadores precoces de transformação neoplásica do cólon, enquanto o exercício físico exaustivo aumentou a prevalência destes em ratos sedentários. O treinamento físico crônico, quando associado ao exercício físico exaustivo, não alterou a prevalência dos biomarcadores estudados. Desse achado, acrescido do que se pode encontrar na literatura científica atual, levanta-se a hipótese de que, de maneira similar à relação entre exercício físico e infecções, também o exercício poderia ou proteger contra o desenvolvimento, ou aumentar o risco para o câncer, dependendo do tipo, intensidade e duração da atividade desenvolvida.

\section{PEDIATRIA}

\section{DETECÇÃO DO VÍRUS DA HEPATITE B NO COLOSTRO DE NUTRIZES IN- FECTADAS E EFEITOS DA PASTEURIZAÇÃO}

\section{Patrícia Ribeiro de Oliveira}

Orientadora: Profa. Dra. Marisa M. Mussi-Pinhata

Dissertação de Mestrado apresentada em 06/04/2005

$\mathrm{O}$ vírus da hepatite $\mathrm{B}$ (VHB) já foi detectado em leite de nutrizes portadoras desse vírus em popu- lações de alta endemicidade da infecção. Não se avaliou a excreção viral em populações brasileiras de baixa endemicidade ou o efeito da pasteurização nessa detecção. Os objetivos desse estudo foram: 1) Avaliar o efeito de um processo de concentração láctea na detecção de AgHBs em nutrizes portadoras do VHB; 
2) Verificar a frequência de detecção do antígeno de superfície do VHB (AgHBs) e do DNA viral no colostro de nutrizes infectadas e analisar a influência do processo de pasteurização nessa detecção. Foram incluídas no estudo 24 puérperas confirmadamente portadoras do AgHBs, das quais foram obtidas 42 amostras de leite (mediana=3dias). De cada participante foi obtida pelo menos 1 amostra de colostro 1 a 4 dias após o parto. Entre as 24 participantes, somente $4(16,7 \%)$ eram também portadoras do AgHBe. As amostras de leite foram avaliadas para a presença do AgHBs por meio de teste imunoenzimático qualitativo e para detecção do DNA-VHB utilizando-se técnica de reação em cadeia de polimerase (PCR), antes e após o processo de pasteurização (aquecimento a $62,5^{\circ}$ $\mathrm{C}$ por $30 \mathrm{~min}$ ). Adicionalmente, todas as amostras "in natura" foram concentradas por ultracentrifugação (fator médio de concentração pré-pasteurização $=3,4 \mathrm{x}$ e pós-pasteurização $=2,4 \mathrm{x}$ ) para repetição dos testes de detecção de AgHBs. Amostras "in natura" concentradas foram testadas para detecção de DNA quando esse resultasse negativo em amostras não concentradas. O mesmo procedimento foi utilizado em amostras pasteurizadas quanto à detecção de AgHBs e DNA. Antes do processamento das amostras lácteas por concentração, em 14 de 41 (34,1\%) delas detectou-se AgHBs, tendo havido incremento significante na freqüência de detecção desse marcador após a concentração $(22 / 41 ; 53,7 \%)(\mathrm{p}=0,0007)$. A avaliação pré e pós-pasteurização dos marcadores foi completa em 35 amostras obtidas. Houve menor freqüência, não significante, de detecção de AgHBs depois da pasteurização $(12 / 35 ; 34,3 \%)$ do que antes $(16 / 35 ; 45,7 \%)$ $(\mathrm{p}=0,46)$. Também quanto ao DNA, somente em 3 amostras inicialmente positivas, após a pasteurização esse não foi detectado $(23 / 35 ; 65,7 \%$ vs. $20 / 35 ; 57,1 \%)$ $(\mathrm{p}=0,62)$. A grande maioria das nutrizes excretava pelo menos um dos marcadores virais detectáveis antes ou após a pasteurização $(78 \%$ vs. $83 \%)$. Não foi observada associação entre a presença de AgHbe sérico ou do DNA sérico na nutriz e a detecção de pelo menos um marcador viral lácteo. Em conclusão, mesmo em nutrizes pertencentes a populações de baixa endemicidade viral, partículas do VHB estão freqüentemente presentes no leite materno, sendo que a sensibilidade de detecção destas partículas melhora após processamento para concentração das amostras. $\mathrm{O}$ processo de pasteurização não modifica significantemente a probabilidade de detecção de DNA viral e de AgHBs lácteos de mães portadoras desse vírus. $\mathrm{O}$ significado biológico desses achados permanece indeterminado. Entretanto, esses dados devem ser considerados quando da seleção de doadoras de bancos de leite humano.

\section{SAÚDE NA COMUNIDADE}

\section{DIRETRIZES PARA A ATUAÇÃo DO FISIOTERAPEUTA NA PREVENÇÃO DE PÉ DIABÉTICO}

\section{Luana Almeida Nogueira Damasceno \\ Orientador: Prof. Dr.Laércio Joel Franco \\ Dissertação de Mestrado apresentada em 05/04/2005}

O objetivo desta investigação foi identificar e classificar, segundo sua freqüência, as condições de risco passíveis de intervenção fisioterápica na prevenção do pé diabético, e estruturar uma proposta de intervenção. A população do estudo foi composta por 41 pacientes portadores de diabetes tipo 2 (18 homens e 23 mulheres) com idade média de 58,3 anos e com tempo médio de diagnóstico de 11,7 anos, atendidos em 2004, no ambulatório de endocrinologia de um Centro de Saúde Escola do município de Ribeirão Preto. Os procedimentos utilizados para coleta de dados foram: entrevista, exame físico e consulta de prontuário médico. Houve predomínio de indivíduos com baixo nível educacional, de aposentados, do lar, de fumantes e ex-fumantes e com consumo regular de bebidas alcoólicas. Poucos praticavam exercícios físicos, e alguns praticavam exercícios inadequados às suas necessidades. Constatou-se baixa adesão à dieta e um mau controle glicêmico, sendo que maioria apresentava hipertensão arterial. Apenas 30\% dos pacientes tinham registro de doença microvascular; 
$25 \%$, de doença macrovascular, e nenhum, de neuropatia em seus prontuários. A maioria (90\%) encontrava-se com sobrepeso ou obesa. Os pacientes não tinham hábito de cuidar dos pés e tendiam a usar calçados inadequados - a maioria não usava meias. Uma parcela importante era portadora de deformidades nos pés $(46,3 \%)$ e $65,9 \%$ dos pacientes apresentavam pele com indícios de isquemia e/ou neuropatia ao exame. Entre os pacientes, $12,2 \%$ apresentavam ausência de ambos pulsos tibial posterior e dorsal do pé; $31,7 \%$, edema; e 48,8\%, enchimento venoso alterado. A dor nos pés estava presente em 53,7\% dos pacientes, sendo limitante em $24,4 \%$. Foram observadas alterações da função neurológica, com perda da sensibilidade vibratória em $29,2 \%$ dos pacientes; alteração dos reflexos miotendíneos em $58,5 \%$; perda da sensibilidade protetora em ao menos um ponto dos pés em $21,9 \%$ e cerca de metade apresentava alterações aos testes de equilíbrio e distúrbio da marcha. Apesar de alguns pacientes terem apresentado uma diminuição da força muscular nos grupos musculares dos pés, todos tinham nível de força considerada funcional. No geral, os pacientes apresentavam mobilidade articular abaixo do esperado em comparação aos valores de referência da literatura. Quando avaliados quanto ao risco para ocorrência de pé diabético, 53,7\% dos pacientes encontravam-se em risco alto. Apesar de reconhecida complicação do diabetes, e do conhecimento do que morbidade que acarreta, observou-se que o investimento na prevenção do pé diabético parece receber atenção insuficiente nos serviços básicos de saúde. A falta de descrição de avaliações neurológicas nos prontuários dos pacientes levanta a questão de se a equipe de saúde está orientada a investigar o principal fator de risco-que é a neuropatia diabética, ou se a anotação dos resultados dos exames nos prontuários é falha. Conclui-se que é importante a implantação de programas de educação permanente dirigidos à equipe de saúde, voltados ao reconhecimento destas complicações, à anotação sistematizada dos resultados dos exames e ao seu papel educativo com os pacientes, familiares e população. De modo geral, os pacientes apresentam alterações passíveis de intervenção. $\mathrm{O}$ fisioterapeuta pode atuar sobre alterações que levam ao risco aumentado de pé diabético, prevenindo-as ou recuperando-as; contribuir na reeducação da sensibilidade protetora visando melhorála ou mantê-la; restabelecer a função motora ou prevenir sua perda; manter ou aumentar a amplitude dos movimentos; preservar ou recuperar o equilíbrio e a propriocepção e orientar o uso de acessórios da marcha, calçados, e adaptar palmilhas. Acresce-se a possibilidade de, junto à equipe multidisciplinar, participar na educação dos pacientes quanto ao auto-cuidado com os pés, para o maior sucesso das abordagens preventivas do pé diabético.

\section{SAÚDE MENTAL}

\section{CONTEÚDOS VERBAIS DE MÃES DE BEBÊS PRÉ-TERMO INTERNADOS EM UTI NEONATAL, DIFERENCIADAS QUANTO A INDICADORES CLÍNICOS EMOCIONAIS DE ANSIEDADE E DEPRESSÃO}

\section{Luciana Leonetti Correia}

Orientadora:Profa. Dra Maria Beatriz M. Linhares

Dissertação de Mestrado apresentada em 17/06/2005

O presente estudo teve por objetivo identificar e comparar os conteúdos verbais maternos, expressos em contexto de um "Programa de Apoio Psicológico a mães de bebês pré-termo hospitalizados em Unidade de Tratamento Intensivo Neonatal (UTIN)", de dois grupos de mães diferenciadas quanto a indicadores clínicos de instabilidade emocional de ansiedade e/ ou depressão. Para a consecução deste objetivo, o presente estudo incluiu um objetivo secundário, de caráter metodológico, o qual visou a elaboração de um sistema de análise de conteúdo das verbalizações maternas em contexto do programa de apoio psicológico durante a hospitalização do bebê em UTIN. A amostra foi composta por 20 mães de recém-nascidos (RN) pré-termo e muito baixo peso ao nascimento que participaram de sessões em grupo áudiogravadas do 
"Programa de Apoio Psicológico a mães de bebês prétermo hospitalizados em UTIN", nas quais foi utilizado um manual de orientações. Essa amostra foi, posteriormente, subdividida, de acordo com os indicadores clínicos emocionais de ansiedade e/ ou depressão, avaliados pelos Inventários de Depressão de Beck e de Ansiedade Traço-Estado-IDATE, sendo 10 mães com indicadores clínicos emocionais (MCIE) e 10 mães sem esses indicadores (MSIE). As sessões gravadas em áudio foram transcritas literalmente. Em seguida, aplicou-se o sistema de categorias para análise do conteúdo verbal dos dados transcritos e foi processada, separadamente, a análise quantitativa descritiva dos resultados, em termos de frequiência e porcentagem dos conteúdos verbais maternos da amostra total de participantes. A análise comparativa entre os grupos de mães com e sem indicadores emocionais foi realizada a fim de verificar possíveis diferenças entre os sentimentos, pensamentos e reações maternas expressas com relação ao nascimento prematuro do seu bebê, levando-se em conta os sintomas de ansiedade e depressão materna. Os resultados mostraram que, em ambos os grupos, as três principais categorias verbalizadas foram: Sentimentos ou reações maternas com conotação negativa, Sentimentos ou reações maternas com conotação positiva e Comunicação $e$ relação com a equipe de saúde. Houve diferença nos tipos de sentimentos e reações verbalizados pelas mães dos grupos MCIE e MSIE. O Grupo MCIE apresentou maior número de expressões de Sentimentos ou reações maternas com conotação negativa em relação ao bebê quando comparado ao Grupo MSIE. Verificou-se que quanto menor o peso ao nascimento do bebê e maior o índice de risco clínico neonatal, maior o tempo de hospitalização do bebê na UTIN. Em relação às associações encontradas entre variáveis neonatais do bebê e verbalizações maternas, o Grupo MCIE apresentou associações entre o índice de risco clínico neonatal e expressões de adaptação, aceitação, superação, esperança ou tranqüilidade diante da condição de prematuridade do bebê e entre o tempo de internação do bebê em UTIN e expressões maternas de busca ativa por informação do bebê. Por outro lado, o Grupo MSIE apresentou uma única associação entre bebês nascidos pequenos para a idade gestacional e expressões maternas referente à comunicação fornecida. Dessa forma, as representações maternas parecem ser influenciadas tanto pelas características neonatais dos bebês, que apresentaram risco moderado de gravidade neonatal, quanto pelos níveis de indicadores clínicos emocionais de ansiedade e depressão identificados nas mães. Os achados mostraram a relevância de identificar os níveis de ansiedade e depressão materna para subsidiar a intervenção psicológica com mães de bebês pré-termo hospitalizados em UTI Neonatal.

\section{INTERAÇÃO ENTRE MÃES E CRIANÇAS PRÉ-ESCOLARES NASCIDAS PRÉ- TERMO E COM MUITO BAIXO PESO EM SITUAÇÕES ESTRUTURADAS LÚDICA E DE ENSINO}

\section{Vivian Caroline Klein}

Profa. Dra. Maria Beatriz Martins Linhares

Dissertação de Mestrado apresentada em 17/06/2005

O presente estudo teve por objetivo verificar a relação entre nascimento prematuro e interação mãecriança aos seis anos de idade, comparando crianças nascidas prematuras com crianças nascidas a termo em duas situações estruturadas de observação sistemática. Além disso, visou verificar a associação entre variáveis maternas e da criança e os indicadores da interação nas díades mãe-criança ex-prematura. A amostra foi composta por 30 crianças de seis anos de idade e suas respectivas mães, distribuídas em dois grupos: Grupo Pré-termo (PT), constituído por 15 crianças nascidas pré-termo (idade gestacional $<37$ semanas) e com muito baixo peso $(\leq 1500 \mathrm{~g})$ e Grupo A
Termo (AT), constituído por 15 crianças nascidas a termo (idade gestacional $\geq 37$ semanas) e com peso adequado $(>2500 \mathrm{~g})$. A coleta de dados foi realizada em duas sessões. Na primeira sessão foi aplicado o Teste das Matrizes Progressivas Coloridas de RavenEscala Especial com a criança e a Escala de Comportamento Infantil A2 de Rutter- ECI e o Teste das Matrizes Progressivas de Raven-Escala Geral com a mãe. Na segunda sessão foi realizada uma situação de observação sistemática da interação mãe-criança, em um contexto estruturado em Momento Lúdico (ML) e Momento de Ensino (ME), com duração máxima de 30 minutos. A sessão foi filmada e gravada em áudio. Os dados de observação da interação mãecriança foram analisados mediante a aplicação do Procedimento de Análise de Interação Mãe-criança elaborado pelos próprios pesquisadores. Para análise 
dos dados de interação, foram realizadas comparações entre os grupos (PT x AT) e entre os momentos da situação de observação (ML x ME), assim como análises de correlação entre variáveis biológicas e psicológicas das crianças e as categorias de interação. Verificou-se que os grupos eram comparáveis quanto ao nível intelectual da criança e da mãe e quanto ao comportamento da criança. Com relação aos indicadores de interação mãe-criança, a análise comparativa entre os grupos revelou que o Grupo PT apresentou significativamente mais atividades realizadas pela criança com participação parcial da mãe nos dois momentos observados e mais atividades realizadas pela mãe sem a participação da criança no ML do que o Grupo AT. As comparações entre os momentos revelaram que o Grupo PT apresentou significativamente mais iniciativas de contato da criança sem resposta da mãe e mais solicitações maternas no ML do que no ME. Ambos os grupos apresentaram significativamente mais iniciativas maternas de contato sem resposta da criança e mais verbalizações da criança orientadas para o jogo simbólico no ML do que no ME. Além disso, observou-se mais atividades realizadas pela criança com participação parcial da mãe e mais informações maternas no ME do que no ML. A análise de correlação revelou que as variáveis clínicas neonatais, nível intelectual e comportamento da criança e as variáveis maternas de idade, escolaridade, ocupação e nível de qualificação profissional do Grupo PT foram associadas a indicadores de interação mãe-criança. Os achados do presente estudo revelaram que o fator de risco do nascimento prematuro consiste em uma variável mediadora da interação mãe-criança no desenvolvimento futuro da criança aos seis anos de idade.

\section{TESES E DISSERTAÇÕES $1^{\circ}$ TRIMESTRE 2005}

\section{CLÍNICA CIRÚRGICA}

\section{EFEITO DO OXIGÊNIO HIPERBÁRICO SOBRE A REGENERAÇÃO HEPÁTICA}

\section{Eduardo Curvêlo Tolentino}

Orientador: Prof. Dr.Orlando de Castro e Silva Jr. Tese de Doutorado apresentada em 03/03/2005

A oxigenoterapia hiperbárica $(\mathrm{OHB})$ é uma modalidade terapêutica que progressivamente vem sendo reconhecida no tratamento de inúmeras doenças. Uma das principais indicações da OHB tem sido estimular a cicatrização de feridas. Na área da hepatologia poucos trabalhos foram encontrados. No presente estudo, procurou-se avaliar o efeito do oxigênio hiperbárico sobre a regeneração hepática e sua relação com a função mitocondrial. Ratos machos Wistar foram submetidos a hepatectomia parcial $(70 \%)$ e a duas sessões de oxigênio hiperbárico, com duração de 90 minutos cada e pressão de 2ATA. Os animais foram sacrificados 24 e 48 horas após a ressecção. A regeneração hepática foi estimada pela avaliação do peso seco do fígado remanescente, da taxa de regeneração hepática, do conteúdo de DNA hepático e do índice de proliferação de hepatócitos, utilizando o mé- todo imuno-histoquímico para PCNA ("proliferating cell nuclear antigen"). A função mitocondrial foi avaliada pelo consumo de oxigênio no estado 3 e 4, pela RCR (razão de controle respiratório), pelo potencial de membrana e o intumescimento osmótico ("swelling") em mitocôndrias isoladas. Os níveis séricos das aminotransferases também foram dosados. Observou-se aumento do peso seco do fígado remanescente, da taxa de regeneração e da dosagem de DNA após 24 e 48 horas da hepatectomia em comparação com animais controles $(\mathrm{p}<0,05)$. $\mathrm{O}$ índice de proliferação hepatocelular foi significativamente maior nos animais tratados com OHB após 48h da cirurgia. Não houve diferença significativa nos níveis de aminotransferase. A avaliação da respiração mitocondrial evidenciou diminuição no consumo de oxigênio no estado 3 (ativado) após 48h. A análise dos resultados demonstra que o oxigênio hiperbárico estimula a regeneração hepática após 24 e 48 horas da cirurgia (hepatectomia 70\%). O efeito do oxigênio hiperbárico sobre o tecido hepático ocorre sem dano tecidual e, aparentemente, com ação protetora sobre a mitocôndria após 48 horas. 


\section{HÁ DIFERENÇAS NO COMPORTAMENTO BIOLÓGICO DOS ADENOMAS HIPOFISÁRIOS EM INDIVÍDUOS JOVENS? ESTUDO CLINICOPATOLÓGICO COM AVALIAÇÃO DO ÍNDICE DE PROLIFERAÇÃO CELULAR, DENSIDADE MICROVASCULAR E DA EXPRESSÃO DAS P27 E P53}

\section{Gisele Gonçalves de Rezende}

Orientador: Prof. Dr. Luciano Neder Serafini

Tese de Doutorado apresentada em 09/03/2005

Adenomas hipofisários (AHs) são tumores raros na infância e adolescência. O comportamento biológico dos AHs nesta faixa etária é assunto controverso na literatura, alguns autores sugerem que eles têm comportamento menos agressivo, enquanto outros discordam desta afirmativa. Para aclarar estes dados, analisamos o comportamento clínico e estudamos o Índice de Proliferação Celular (IPC), a densidade microvascular (DMv), a expressão da p27 e p53 em AHs de indivíduos menores de 20 anos e os comparamos com os AHs de pacientes adultos. Esta casuística incluiu $15 \mathrm{AHs}$ de pacientes com idade inferior a 20 anos (Grupo I, idade média 13,3 $\pm 3,6$ anos) e outros 15 casos de AHs de adultos (Grupo II, idade média 39,6 $\pm 11,7$ anos). A expressão da p27 e o IPC foram determinados pela contagem de $10^{3}$ núcleos neoplásicos p27 e MIB-1 imunorreativos, respectivamente. A DMv foi obtida pela contagem do nímero de microvasos (CD34 +) em uma área de $0,24 \mathrm{~mm}^{2}$. A expressão da p53 foi considerada positiva se ao menos $5 \%$ dos núcleos eram imunomarcados. A contagem foi feita sem prévia identificação do caso. Não há diferenças estatísticas significativas entre ambos os grupos no que concerne o IPC-MIB-1 (mediana de $0,7 \% \pm 1,1$ versus $0,3 \% \pm 0,7, \mathrm{p}=0.63$ ), expressão da p27 (mediana de 40,3\% $\pm 37,5$ versus $16,9 \%$ $\pm 33,4, \mathrm{p}=0.67)$ e $\mathrm{DMv}(51 \pm 39$ vasos versus $47 \pm 47$ vasos $/ 0,24 \mathrm{~mm}^{2}, \mathrm{p}=0,91$, Mann-Whitney $U$-test), além de raros casos imunorreativos para a p53. Ainda, o comportamento clínico foi semelhante em ambos os grupos. Em conclusão, a imunoexpressão dos marcadores moleculares (MIB-1, p27 e p53), a densidade microvascular e o comportamento biológico dos AHs independe da idade dos pacientes.

\section{FARMACOLOGIA}

\section{CONSEQÜÊNCIAS CELULARES E FUNCIONAIS DO CONSUMO CRÔNICO DE ETANOL SOBRE O SISTEMA ENDOTELINA VASCULAR}

\section{Carlos Renato Tirapelli}

Orientadora: Profa. Dra. Ana Maria de Oliveira

Tese de Doutorado apresentada em 03/03/2005

O consumo crônico de etanol leva a alterações significativas das funções cardíaca e circulatória, figurando como um importante fator de risco no desenvolvimento de doenças cardiovasculares. Nossos resultados mostram que em anéis de aorta torácica isolados, não houve alteração da resposta de contração induzida pela ET-1 após tratamento com etanol (solução $20 \%$ ) por 2, 6 ou 10 semanas. Observou-se aumento da resposta contrátil a fenilefrina em anéis de aorta após os três diferentes períodos de tratamento. A hiperreatividade a fenilefrina é independente do endotélio e envolve aumento da liberação/produção de prostanóides vasoconstritores de origem muscular (possivelmente $\mathrm{PGH}_{2}$ ou TXA $\mathrm{TX}_{2}$, que regulam o aumento de influxo de $\mathrm{Ca}^{2+}$ do meio extracelular.

Nos anéis isolados de carótida com endotélio, houve aumento da resposta contrátil à ET-1 após 2, 6 ou 10 semanas de tratamento com etanol. O relaxamento induzido pela ET-1 e pelo IRL1620 (agonista seletivo dos receptores $\mathrm{ET}_{\mathrm{B}}$ ) em anéis de carótida précontraídos com fenilefrina, foi menor após tratamento com etanol. Evidenciou-se que o tratamento com etanol não altera os níveis de RNAm para os receptores $\mathrm{ET}_{\mathrm{A}}$ e $\mathrm{ET}_{\mathrm{B}}$. No entanto, o tratamento induz redução da expressão protéica dos receptores $\mathrm{ET}_{\mathrm{B}}$ endoteliais, que promovem relaxamento vascular. Essas observações 
indicam que a hiperreatividade à ET-1 está relacionada à redução do relaxamento vascular mediada pelos receptores $\mathrm{ET}_{\mathrm{B}}$ endoteliais.

O consumo crônico de etanol não altera os níveis de RNAm para a pré-pró-ET-1 em anéis de carótida. Não se evidenciou alteração dos níveis basais de ET-1 em anéis de carótida após tratamento com etanol. No entanto, o tratamento com etanol promoveu redução da resposta de contração induzida pela Big-ET-1 em anéis de carótida com endotélio após os três períodos de tratamento. Essa resposta indica que o tratamento com etanol altera o mecanismo de conversão da Big-ET-1 em ET-1, que envolve a ação da Enzima Conversora de Endotelina (ECE).
O tratamento com etanol induz aumento da pressão arterial média basal após 2, 6 e 10 semanas de tratamento. Houve aumento da resposta pressora induzida pela ET-1 em animais tratados com etanol, indicando que o tratamento altera o padrão de resposta do sistema endotelinérgico, que participa da manutenção basal do controle da pressão arterial.

O sistema endotelinérgico assim como o consumo crônico de etanol está relacionado à isquemia cerebral, acidente vascular cerebral e ao aumento da pressão arterial. Nesse sentido, o presente trabalho estabelece correlação positiva entre esses dois fatores onde o tratamento com etanol promove alterações no sistema endotelinérgico vascular.

\section{GENETICA}

\section{ANÁLISES MOLECULARES EM GENES SUPRESSORES TUMORAIS DA FAMÍ- LIA INK4/ARF EM TUMORES DO SISTEMA NERVOSO HUMANO}

\section{Luciana Oliveira de Olmeida}

Orientadora: Profa. Dra. Cacilda Casartelli

Dissertação de Mestrado apresentada em 31/03/2005

O câncer é um dos problemas mais comuns e intensos da medicina clínica; as estatísticas mostram que o câncer atinge de algum modo mais de um terço da população mundial, sendo que os tumores do sistema nervoso representam aproximadamente $2 \%$ dos tipos de câncer. O papel central do sistema nervoso e as conseqüências funcionais da perda de neurônios podem explicar a severidade dos tumores cerebrais. A formação dos tumores do cérebro humano é um processo complexo, envolvendo um acúmulo de alterações genéticas. Um dos fatores mais importantes na carcinogênese é um aumento da proliferação celular, sendo que a divisão celular é essencial para o início de neoplasias. O ciclo celular representa um processo de alta complexidade, no qual um amplo número de proteínas regulatórias está envolvido. Essas proteínas podem sofrer alterações causadas por vários fatores, podendo direcionar a transformação de uma célula normal em maligna. Os membros da família INK4 (Ini- bidores de CDKs) são reguladores do ciclo celular que atuam de forma competitiva, ligando-se diretamente às CDKs 4 e 6 e impedindo sua associação com a ciclina $\mathrm{D}$, fazendo com que as proteínas $\mathrm{RB}$ permaneçam em atividade, impedindo que o ciclo celular progrida através do ponto $R$, provocando assim uma parada em G1. O gene p14ARF (Alternative Reading Frame) é um supressor tumoral que inibe a degradação de p53 durante a progressão do ciclo celular. $\mathrm{O}$ objetivo deste trabalho foi avaliar o estado mutacional dos genes p14ARF, p15INK4B e p16INK4A através de técnicas de biologia molecular. Foram estudadas 64 amostras de tumores de sistema nervoso; destas, dois schwanomas apresentaram deleções homozigotas no éxon 2 do gene p15 e no éxon 3 do p16 e três amostras (ependimoma, astrocitoma difuso e adenocarcinoma metastático) apresentaram deleção de uma guanina (códon 63) de p15. Outros mecanismos de silenciamento gênico como a metilação do DNA também estão freqüentemente envolvidos na inativação destes genes; assim, o lócus INK4/ARF parece apresentar a segunda maior freqüência de envolvimento nos cânceres humanos. 


\section{IMUNOLOGIA BÁSICA EAPLICADA}

\section{AVALIAÇÃO DO EFEITO PLEIOTRÓPICO DA INTERLEUCINA-12 SOBRE A EXPRESSÃO GÊNICA DE LINFÓCITOS HUMANOS T CD4+ (JURKAT E6-1)}

\section{Pryscilla Fanini Wowk}

Orientador: Prof. Dr. Geraldo Aleixo da Silva Passos Dissertação de Mestrado apresentada em 25/02/2005

A interleucina-12 (IL-12) é a principal molécula moduladora da resposta imune primária contra micróbios intracelulares e é a chave indutora da imunidade mediada por células que leva à resposta imune adaptativa a estes micróbios. Produzida principalmente por fagócitos mononucleares e células dendríticas, estimula a produção de IFN-gama nas células natural killer (NK), nos linfócitos T e a diferenciação dos linfócitos $\mathrm{T}$ CD4+ em células Th1 que produzem IFN-gama, e também realça a função citolítica das células NK ativadas e dos linfócitos citotóxicos T CD8+ (CTLs).

Já que a IL-12 tem efeito na indução da formação de IFN-gama pelas células T, é razoável pensarmos que esta interleucina poderá também modular a expressão de vários outros genes, exercendo na realidade um efeito pleiotrópico.

Com o advento da tecnologia dos cDNA microarrays passamos a ter uma importante ferramenta para a identificação, de forma mais abrangente, de genes diferencialmente expressos em resposta à ação de citocinas.

Com o intuito de estudarmos o efeito pleiotrópico da IL-12 em células cujo fenótipo fosse o mais próximo possível das células T auxiliares naives, utilizamos linfócitos T CD4 ${ }^{+}$humanos, linhagem Jurkat-E6-1, não estimulados por antígenos, porém cultivados na presença de IL-12, como sistema-modelo.

As células foram cultivadas durante 6, 12 e 18 horas na presença de IL-12 em diferentes concentrações $(0,1 ; 1$ e $10 \mathrm{ng} / \mathrm{ml}$ de cultura) ou na ausência da mesma (controle). Para o estudo de expressão gênica destas células, extraiu-se o RNA total que por sua vez foi convertido em DNA complementar (cDNA) total na presença do isótopo ${ }^{33} \mathrm{P}$ (sonda complexa radioativa). Preparou-se um cDNA microarray em nylon contendo 780 clones de cDNA referentes a genes relacionados ao sistema imune. Tais clones são provenientes de bibliotecas IMAGE totalmente caracterizadas. As sondas complexas foram hibridadas com o microarray a cujas imagens de hibridação foram atribuídos valores numéricos de quantificação, os quais foram normalizados. Com auxílio de programas de bioinformática aplicados a análise de dados de microarrays realizou-se os cálculos estatísticos e o agrupamento dos dados (genes) por meio de dendrogramas.

Os resultados mostraram que a IL-12 modulou a expressão de 141 genes associados ao sistema imune nas células T $\mathrm{CD}^{+}$. Dentre os genes modulados, destacamos TNFRSF10B, SRPK2, PDCD4, BCL2like, CALM1 e SOCS2, que representam genes "novos", ainda não descritos na literatura como modulados pela IL-12, mostrando que esta interleucina exerce um efeito abrangente nas células alvo.

\section{NEUROLOGIA}

\section{EFEITO COMBINADO DE SUBSTÂNCIAS ANTIOXIDANTES COM INIBIDOR DE RECEPTOR DE DOPAMINA OU INIBIDORES DA SINTASE DO ÓXIDO NÍTRICO SOBRE A INDUÇÃO DE CATALEPSIA EM CAMUNDONGOS}

\section{Márcio Lazzarini}

Orientadora: Profa Dra Elaine A. Del Bel Guimarães

Dissertação de Mestrado apresentada em 17/01/2005
Introdução A catalepsia, caracterizada por posturas incorretas/não-usuais e imobilidade é modelo experimental do parkinsonismo induzido por dro- 
gas, que ocorre em humanos tratados com antipsicóticos típicos. Também é equivalente a um dos sintomas motores da doença de Parkinson, a acinesia. Tem sido demonstrado que os antioxidantes podem modular o comportamento motor através da neurotransmissão de dopamina.

O objetivo deste estudo é analisar a modulação da catalepsia induzida por inibidores da Sintase do Óxido Nítrico (NOS) e Haloperidol (Hal). Para isso estudamos: i- se a catalepsia induzida por inibidores da NOS, à semelhança do que ocorre com a catalepsia produzida por Hal, é influenciada por substâncias antioxidantes como as vitaminas $\mathrm{C}, \mathrm{E}$ e a melatonina; ii- se a vitamina $C$ influencia o desenvolvimento da tolerância à catalepsia produzida por L-NOARG; iiise a catalepsia induzida por inibidores da NOS e por Hal é influenciada pelo ciclo circadiano, o qual influencia o comportamento motor.

Material e Método: A catalepsia foi avaliada em camundongos albinos machos Suíço por meio do teste da barra (tempo de corte de 300 segundos).
Resultados: O ácido ascórbico (90-1000 mg/ $\mathrm{kg}$, i.p.), potenciou a catalepsia induzida por $\mathrm{Hal}(1 \mathrm{mg} /$ $\mathrm{kg}$ i.p ANOVA $\mathrm{p}<0,001)$ e inibidores da NOS: LNOARG (10 e $40 \mathrm{mg} / \mathrm{kg}$, ANOVA, p<0,001), LNAME $(20-80 \mathrm{mg} / \mathrm{kg}$, ANOVA, $\mathrm{p}<0,001)$ e 7NI (30 $\mathrm{mg} / \mathrm{kg} ; \mathrm{p}=0,012)$. O ácido ascórbico $(90 \mathrm{mg} / \mathrm{kg})$ não previniu a tolerância à catalepsia induzida por tratamento crônico com LNOARG (40 mg/kg, 2 X dia X 4 dias ANOVA, $\mathrm{p}<0,001)$. A Vitamina $\mathrm{E}(100 \mathrm{mg} / \mathrm{kg})$ e a melatonina $(15 \mathrm{mg} / \mathrm{kg})$ aumentaram a catalepsia induzida por LNOARG $(40 \mathrm{mg} / \mathrm{kg}$, ANOVA, $\mathrm{P}<0.05)$ e Hal $(1 \mathrm{mg} / \mathrm{kg}$ ANOVA, $\mathrm{P}<0.05)$. A catalepsia induzida no período diurno por LNOARG, Hal e Pilocarpina foi maior que no período noturno (ANOVA; $\mathrm{p}<0,001$ ).

Conclusões: Os resultados mostraram que as substâncias antioxidantes potenciam a catalepsia induzida por Hal e inibidores de NOS, de forma dosedependente. Estes resultados são importantes no estudo de possíveis novas substâncias antipsicóticas e sugerem cautela no uso conjunto de vitaminas e outras drogas antioxidantes.

\section{COMPARAÇÃO DA QUALIDADE DE VIDA RELACIONADA À SAÚDE ENTRE PACIENTES COM EPILEPSIA FOCAL, MIGRÂNEA EPISÓDICA E MIGRÂNEA CRÔNICA NO AMBULATÓRIO DE UM CENTRO TERCIÁRIO}

\section{Hilton Mariano Da Silva Junior}

Orientador: Prof. Dr. José Geraldo Speciali

Tese de Doutorado apresentada em 28 /01/2005

O interesse pelo conceito de qualidade de vida na área de saúde decorre do fortalecimento da concepção biopsicossocial do processo saúde-doença, paradigma que tem influenciado as políticas e as práticas de saúde nas últimas décadas. A migrânea e a epilepsia são condições neurológicas freqüentemente associadas a um grande ônus social e individual. $\mathrm{O}$ objetivo deste estudo foi comparar a qualidade de vida relacionada à saúde entre mulheres com epilepsia focal, migrânea episódica e migrânea crônica acompanhadas no ambulatório de um centro terciário (HCFMUSP-RP). Foram excluídas as pacientes que apresentavam relato de moléstias que pudessem confundir a associação entre epilepsia, migrânea e qualidade de vida. As pacientes participantes do estudo foram 62 mulheres com o diagnóstico de epilepsia focal, 66 mulheres com migrânea episódica e 70, com migrânea crônica. Todas foram atendidas consecutivamente nos ambulatórios especializados e completaram o questionário Brasil (SF-36). Não houve diferenças estatisticamente significativas entre os grupos em relação à idade e ao nível de instrução. As médias dos resultados dos oito aspectos do SF-36 foram comparadas entre os grupos.

As pacientes com migrânea crônica relataram significativamente pior qualidade de vida na comparação com as pacientes com epilepsia nos parâmetros limitação física, dor e aspectos sociais. Diferenças estatisticamente significativas entre as formas episódica e crônica da migrânea foram relatadas para sete parâmetros, exceto vitalidade. As mulheres com epilepsia relataram significativamente pior qualidade de vida, quando comparadas com as pacientes com migrânea episódica, nos parâmetros estado geral de saúde e saúde mental. Vários fatores, tais como o estigma social associado à epilepsia e as características debilitantes das crises de migrânea podem explicar esses resultados. 


\section{ORTOPEDIA, TRAUMATOLOGIA E REABILITAÇÃO}

\section{ANÁLISE ELETROMIOGRÁFICA DA FREQÜÊNCIA MEDIANA DO MÚSCULO QUADRÍCEPS DA COXA EM INDIVÍDUOS COM LESÃO DO LIGAMENTO CRU- ZADO ANTERIOR}

\section{Juliano Coelho Arakaki}

Orientadora: Profa. Dra. Débora Bevilaqua Grossi

Dissertação de Mestrado apresentada em 29/03/2005

O presente estudo teve como objetivo comparar os valores da frequiência mediana (FMED) do espectro de potência do sinal eletromiográfico de superfície dos músculos reto da coxa (RC), vasto lateral longo (VLL) e vasto medial oblíquo (VMO) em indivíduos com lesão do LCA e indivíduos controles. Participaram desse estudo 40 voluntários, homens ( $n=80$ joelhos) igualmente divididos em 4 grupos. Os voluntários com lesão do LCA $(\mathrm{n}=20$, idade média $31.1 \pm$ 7.45 anos, altura média $174 \pm 6.65 \mathrm{~cm}$ ), confirmada através da positividade de testes clínicos e KT-1000, constituíram o grupo LCA lesado (LCA-L) e o grupo LCA contralateral (LCA-CL). Vinte voluntários clinicamente saudáveis $(\mathrm{n}=20$, idade média $22.2 \pm 3.15$ anos, altura média $175 \pm 8.55 \mathrm{~cm}$ ) constituíram o grupo controle dominante (C-D) e grupo controle nãodominante (C-ND). Os indivíduos foram instruídos, de forma aleatória, a realizarem 3 séries de contrações isométricas voluntárias máximas (CIVM) de extensão do joelho por 5 segundos no dinamômetro isocinético Biodex Multi Joint System III nos ângulos de $30^{\circ} \mathrm{e}$ $60^{\circ}$ de flexão do joelho, com 2 minutos de intervalo entre as séries e ângulos. Os sinais SEMG foram adquiridos com eletrodos ativos diferenciais (2 barras retangulares de prata pura de $10 \times 2 \mathrm{~mm}$, espaçadas por $10 \mathrm{~mm}$, impedância de entrada maior que $10 \mathrm{G} \Omega$,
CMRR mínimo de $130 \mathrm{~dB}$ e ganho de 2 vezes). Os sinais SEMG foram analogicamente filtrados (Butterworth 10-1500 Hz de passa-faixa) e amplificados com freqüência de amostragem de $2 \mathrm{KHz}$ por placa conversora A/D de 12 bits de resolução. Os sinais SEMG brutos foram digitalmente filtrados passa-faixa de $20-1000 \mathrm{~Hz}$ e os dados da FMED (PSD, FFT, 250 $\mathrm{ms}, 1024$ pontos, janela de processamento Hamming) foram normalizados pelos valores de FMED da CIVM de extensão do joelho a $90^{\circ}$ de flexão. Foram realizadas análises estatísticas intra e inter-grupos através do método de análise de variância (ANOVA) com medidas repetidas e, se necessário, a técnica de formação de contrastes e pós-teste de Bonferroni com nível de significância $\mathrm{p} \leq 0.05$. Os resultados dos valores da FMED na comparação entre os grupos demonstraram não haver diferenças estatísticas ( $\mathrm{p} \geq 0.11)$. Entretanto, o músculo VLL apresentou valores menores de FMED no grupo LCA-L em comparação com o grupo LCA-CL ( $\mathrm{p}=0.02)$ devido ao VLL agir como um componente do mecanismo de proteção do fenômeno de pivô encontrado em joelhos com lesão do LCA. Em conclusão, os valores da FMED dos músculos RC e VMO dos joelhos com lesão do LCA não apresentaram diferenças estatisticamente significativas quando comparados com joelhos contralaterais à lesão e joelhos controles. Portanto, a lesão do LCA não pode ser um fator determinante de mudanças nos valores da FMED do músculo quadríceps da coxa nessas condições experimentais.

\section{SAÚDE NA COMUNIDADE}

\section{QUEDAS DE IDOSOS INSTITUCIONALIZADOS: OCORRÊNCIA E FATORES ASSOCIADOS}

Daniela Cristina Lojudice

Orientador: Prof. Dr. Milton Roberto Laprega

Dissertação de Mestrado apresentada em 10/02/2005
Quedas entre pessoas idosas constituem importante problema de saúde pública devido à sua incidência, às complicações para a saúde e aos altos custos 
assistenciais. Estudos realizados no Brasil e em outros países referem que as quedas são mais freqüentes em idosos institucionalizados e apresentam causa multifatorial. Com o objetivo de verificar a ocorrência de quedas em idosos institucionalizados e identificar os seus fatores determinantes, foi realizado um levantamento de dados de 105 indivíduos com idade igual ou superior a 60 anos, residentes em 4 instituições asilares do município de Catanduva, São Paulo. O método utilizado para a coleta dos dados foi entrevista. Foram utilizados os instrumentos: GDS (Escala de Depressão Geriátrica), MEEM (mini Exame do Estado Mental) e a escala de Equilíbrio e Marcha de Tinetti, instrumentos estes destinados à avaliação dos estados de hu- mor, cognitivo e equilíbrio e marcha respectivamente. Os achados mostraram que $40 \%$ dos idosos relataram quedas nos últimos 6 meses, e os fatores de risco considerados significativos foram: sexo feminino $(\mathrm{p}=0,035)$, uso de medicamentos $(\mathrm{p}=0,047)$, visão deficiente $(\mathrm{p}=0,029)$, ausência de atividade física $(\mathrm{p}=0,035)$, presença de osteoartrose $(\mathrm{p}=0,000)$, Depressão $(\mathrm{p}=0,034)$, déficit de força de preensão palmar $(\mathrm{p}=0,0165)$ e distúrbios no equilíbrio e marcha $(\mathrm{p}=0,038)$. Os resultados apontam para a necessidade da implementação de programas de prevenções de quedas em instituições asilares, através de intervenção multidisciplinar buscando, portanto, uma melhoria na qualidade de vida dessa população.

\section{ESTUDO EPIDEMIOLÓGICO SOBRE PNEUMONIA HOSPITALAR EM PACI- ENTES COM TRAUMA POR ACIDENTE DE TRANSPORTE}

\section{Rosana Claudia Lovato Pagnano}

Orientador: Prof. Dr. Amaury Lelis Dal Fabbro

Dissertação de Mestrado apresentada em 11/02/2005

O trauma é uma doença que representa um problema de saúde pública de grande magnitude e transcendência no Brasil, que tem causado forte impacto na morbidade e mortalidade da população, com profundas repercussões nas estruturas sociais, econômicas e políticas de nossa sociedade. Diante da necessidade de métodos de diagnóstico e tratamento invasivos e devido à lesão traumática criar um estado de relativa imunossupressão, a evolução clínica do politraumatizado apresenta muitas variáveis que se destacam como fatores de risco para infecções hospitalares, dentre elas a pneumonia hospitalar. Esta investigação tem por objetivo estimar a incidência de pneumonia hospitalar em pacientes com trauma por acidente de transporte, identificar aqueles que desenvolveram a infecção segundo sexo, idade, doenças de base, segmento(s) afetado(s), gravidade da lesão, tempo de permanência da internação hospitalar, condições de alta, intubação endotraqueal e/ou traqueostomia, uso de ventilação mecânica, realização de toracotomia e drenagem torácica, uso de antimicrobianos profiláticos e realização de procedimentos cirúrgicos, e identificar fatores de risco para seu aparecimento. Foi realizado um estudo analítico, transversal, no qual a população estudada foi de pacientes com trauma por acidente de transporte, atendidos na Unidade de Emer- gência do Hospital das Clínicas da Faculdade de Medicina de Ribeirão Preto - Universidade de São Paulo. O processamento dos dados foi realizado utilizandose programas STATA 2.0 e Epi-Info versão 2002 e para o modelo de regressão logística múltiplo o programa usado foi o SAS versão 8. Do total de 309 registros levantados, 44 foram excluídos do levantamento, resultando em 265 prontuários considerados como a amostra do estudo. Os critérios de inclusão usados foram referentes a todas as vítimas de acidente de transporte, com idade maior ou igual a 12 anos, que permaneceram internados por período mínimo de 48 horas, durante os meses de janeiro a dezembro de 2002. A média de idade foi de 33,4 anos com mediana de 30 (amplitude de variação entre 12 a 80 anos), sendo que $224(84,5 \%)$ eram do sexo masculino e $41(15,5 \%)$ do sexo feminino. A média para o Injury Severity Score (ISS) foi de 13,2 com mediana de 9 (amplitude de variação entre 1 a 75). O tempo médio de internação hospitalar foi de 12,3 dias com mediana de 7 dias (amplitude de variação entre 2 a 80 dias). Dos 265 pacientes da amostra, 59 internaram no Centro de Terapia Intensiva $(22,2 \%)$ mostrando média de permanência de 14 dias com mediana de 10 (amplitude de variação entre 1 a 75 dias). A taxa de incidência encontrada para a pneumonia hospitalar foi de $15,1 \%$, onde o tempo médio de comprovação do diagnóstico foi de 6 dias. $\mathrm{O}$ modelo de regressão logística múltiplo encontrou que a variável sexo apresenta um risco adicional de 1,75 para a pneumonia nas mulheres (Odds Ratio ajustado 
de 16,0; $\mathrm{p}=0,02)$. Constatou-se também que o ISS, a intubação traqueal e a drenagem torácica apresentaram percentuais maiores no sexo feminino em relação ao masculino. Na amostra total foi encontrado que o trauma de cabeça apresenta um risco adicional de 16,36 (Odds Ratio ajustado de 6,79; $\mathrm{p}=0,04$ ). Para a gravidade do nível da lesão o teste mostrou significância para os valores do ISS entre 19 a 22, dando um risco adicional de 82,22 (Odds Ratio ajustado de 59,61; $p=0,04)$. Para os dias de internação hospitalar ocorreu uma forte significância no reagrupamento, cujo intervalo de permanência hospitalar variou de 16 a 80 dias, apresentando um risco adicional de 48,66 (Odds Ratio ajustado de 135,$61 ; p<0,01)$. O procedimento de intubação traqueal mostrou risco adicional de 63,00 (Odds Ratio ajustado de 45,68; $p<0,01$ ) e para a drenagem torácica encontramos um risco adicional de 9,33 (Odds Ratio ajustado de 13,64; $p=0,04$ ). Como conclusão, este estudo indica que a incidência de pneumonia hospitalar se deve principalmente ao fato desta população ter sido submetida a procedimentos invasivos de tratamento, fato demonstrado também na literatura. Entretanto, na população estudada vimos que o nível de gravidade da lesão e o tempo de permanência hospitalar mostram-se menores em relação a outros estudos. Estes resultados fornecem uma linha de base para discussões sobre mudanças na abordagem destes doentes.

\section{IMPACTO DA INFORMATIZAÇÃO NA DISPENSAÇÃO DE MEDICAMENTOS EM UM HOSPITAL UNIVERSITÁRIO}

\section{Sonia Aparecida Dias Serafim}

Orientadora: Profa. Dra. Aldaísa Cassanho Forster

Dissertação de Mestrado apresentada em 17/02/2005

Este trabalho foi realizado no período de 06 de abril de 2004 a 21 de julho de 2004, com o objetivo de descrever a estrutura e funcionamento do sistema informatizado para controle da dispensação de medicamentos na Divisão de Assistência Farmacêutica do Hospital das Clínicas da Faculdade de Medicina de Ribeirão Preto da Universidade de São Paulo, bem como avaliar os resultados obtidos com a sua implantação em relação aos serviços de enfermagem e farmacêutico. Foi aplicado um formulário padronizado a 58 enfermeiros, 10 farmacêuticos e 15 auxiliares de farmacêutico que participaram da fase de estruturação, para avaliar a sua opinião quanto aos aspectos relativos à requisição de medicamentos, à forma de apresentação dos medicamentos dispensados pela far- mácia hospitalar e à operacionalização do sistema. Como resultados observou-se que para estes profissionais, as principais vantagens obtidas foram: a eliminação da transcrição manual para requisição do medicamento prescrito, a rapidez, a melhor identificação das doses prescritas pelo médico, a embalagem dos medicamentos contendo toda a identificação necessária e a conferência do medicamento requisitado e dispensado através da leitura óptica do código de barras. Os resultados deste estudo permitiram-nos concluir que a grande maioria dos entrevistados considerou o sistema informatizado de dispensação de medicamentos de boa qualidade. A análise dos dados aqui descritos, embora possa não englobar algumas dimensões importantes na busca de uma terapia medicamentosa mais racional, forneceu subsídios que podem contribuir para a expansão e o aperfeiçoamento do sistema, visando dar suporte à realização de estudos de utilização de medicamentos e proporcionar novas perspectivas de trabalho e produtividade.

\section{CONHECIMENTOS E ATITUDES SOBRE A ATUAÇÃO PROFISSIONAL DO FISIOTERAPEUTA ENTRE OS PROFISSIONAIS DA EQUIPE MÍNIMA DE SAÚDE DE FAMÍLIA EM RIBEIRÃO PRETO}

\section{Ricardo Goes de Aguiar}

Orientadora: Profa. Dra. Elisabeth Meloni Vieira

Dissertação de Mestrado apresentada em 18/02/2005
O Programa de Saúde da Família (PSF) surge no Brasil em 1994, tendo como objetivo ofertar cuidados primários à população, calcados na atenção inte- 
grais ao indivíduo e à comunidade, configurando-se como a porta de entrada do sistema de saúde. A fisioterapia é uma profissão nova, relativamente a outras profissões da área da saúde e, ainda hoje, o acesso da população à assistência fisioterapêutica é limitado, e o conhecimento de qual seja sua atuação, até mesmo entre outros profissionais da área de saúde, parece ser relativamente restrito. $\mathrm{O}$ presente estudo teve o objetivo de analisar os conhecimentos e atitudes em relação à atuação profissional do fisioterapeuta entre os profissionais das Equipes mínimas de Saúde da Família de Ribeirão Preto (SP). Trata-se de um estudo de corte transversal, quantitativo, utilizando como instrumento de pesquisa um questionário elaborado pelo próprio pesquisador. Faziam parte da população da pesquisa todos os profissionais que atuavam no PSF em Ribeirão Preto, tendo sido entrevistados 109 profissionais. Os resultados demonstraram que os profissionais das equipes são predominantemente do sexo feminino, acima dos 40 anos, de cor branca, haviam freqüentado pelo menos o ensino médio, com doze ou mais anos de estudo, pertenciam as classes econômicas A ou B, tinham três anos ou mais de atuação no PSF e estavam há quatro anos ou menos na área da saúde. A maioria dos entrevistados considerou necessária a inclusão de outros profissionais no PSF $(91,7 \%)$, sendo que $48,6 \%$ citaram a necessidade do fisioterapeuta. O grau de conhecimento geral sobre os diversos aspectos da atuação do fisioterapeuta mostrou-se suficiente, com uma média de acertos de 16,2 pontos, que correspondeu a $64,8 \%$ do teste. Foi encontrada associação estatisticamente significante entre conhecimento da atuação do fisioterapeuta e a escolaridade, tempo de estudo, ocupação, tempo de atuação área da saúde, classificação econômica e vínculo institucional da Unidade de Saúde da Família. Quase a totalidade dos profissionais $(99,1 \%)$ demonstrou atitudes positivas em relação à atuação do fisioterapeuta. $\mathrm{O}$ grau de conhecimento se mostrou suficiente para que os profissionais que atuam junto à comunidade no PSF saibam identificar em quais casos há a possibilidade de intervenção fisioterapêutica.

\section{COMPOSIÇÃO CORPORAL NAS DIFERENTES FASES DO DESENVOLVIMEN- TO SEXUAL DOS ADOLESCENTES DE ESCOLAS PÚBLICAS E PRIVADAS DE RIBEIRÃO PRETO-SP}

\section{Érika da Silva Bronze}

Orientador: Prof. Dr. Antonio Dorival Campos

Dissertação Mestrado apresentada em 23/02/2005

A adolescência é um período de modificações rápidas e dramáticas nos estados físico, cognitivo e emocional, quando ocorre aumento da massa gorda total. Nas meninas esse acréscimo acontece durante toda a puberdade, enquanto nos meninos ele reduz no decorrer da puberdade. Desta forma, a puberdade é um importante período para o desenvolvimento da obesidade, pois além das modificações de composição corporal, os hábitos alimentares dos adolescentes são marcados pelo grande consumo de alimentos altamente calóricos e ricos em lipídeos. Assim, o presente estudo propõe analisar a associação entre as fases de desenvolvimento sexual de adolescentes, matriculados em escolas das redes pública e privada da cidade de Ribeirão Preto-SP, com a composição corporal e o perfil antropométrico dos mesmos. A amostra do estudo foi constituída por 494 adolescentes de ambos os sexos, idade entre 10 a 19 anos, diferentes estratos socioeconômicos e pertencentes a 23 escolas de Ribeirão Preto-SP. A avaliação dos adolescentes consistiu na auto- avaliação do desenvolvimento sexual proposto por Marshall e Tanner, 1969, das atividades físicas e sedentárias, na aferição de medidas antropométricas de peso, altura, pregas cutâneas, circunferências e bioimpedância. A prevalência de excesso de peso encontrada foi de $20,65 \%$ para os meninos e $16,60 \%$ para as meninas. Por outro lado, os resultados evidenciaram diferença estatisticamente significante dos IMCs médios dos adolescentes do sexo masculino entre os estratos econômicos $(\mathrm{p}=0,0026)$, o que não ocorreu para o sexo feminino. O coeficiente de correlação de Pearson evidenciou associação positiva e estatisticamente significante, para ambos os sexos, entre o IMC e as características: idade, estágio de maturação sexual, peso corporal, altura e porcentagem de gordura corporal determinada pelos três métodos $\left(\right.$ Tanita $^{\circledR}$, Bioimpedância, e pregas cutâneas). Contudo, os valores encontrados sugerem que o estágio de maturação sexual é fator mais determinante do IMC do que a idade. Ao se comparar os valores de "ridit analyses" da variável maturação sexual com a razão cintura/quadril, circunferência de cintura, percentual de gordura corporal, IMC e classificação econômica foram encontradas diferenças estatisticamente significantes 
entre todos esses valores para o sexo feminino. Já para o sexo masculino, somente entre circunferência de cintura, percentual de gordura corporal, determinado pela Tanita $^{\circledR}$, IMC e classificação econômica foram verificadas diferenças estatisticamente significantes. Observou-se diferenças estatisticamente significantes entre a maturação sexual e o sexo $(\mathrm{p} \cong 0,000)$, porém, o comportamento dos adolescentes do mesmo sexo na escola pública foi igual ao dos adolescentes das escolas privadas. Portanto, as modificações na composição corporal são distintas entre os sexos, isto é, nas meninas o aumento do percentual de gordura corporal é correlacionado com o aumento do IMC, idade, estágio de maturação sexual, altura e peso, enquanto nos meninos, apenas acontece com o peso, além de se sugerir que nesse sexo o incremento de gordura corporal é inversamente correlacionado com a idade, altura e estágio de maturação sexual.

\section{CARACTERÍSTICAS DOS CUIDADORES DE IDOSOS DEPENDENTES NO CONTEXTO DA SAÚDE DA FAMÍLIA}

\section{Tatiana Lemos de Almeida}

Orientadora: Profa. Dra. Aldaísa Cassanho Forster Dissertação de Mestrado apresentada em 24/02/2005

A prevenção das doenças crônicas e degenerativas juntamente com a assistência à saúde do idoso e o suporte aos cuidadores familiares representam novos desafios para o nosso sistema de saúde. Cuidar de quem cuida é também uma responsabilidade dos profissionais de saúde. O presente estudo teve como objetivos caracterizar os cuidadores informais de idosos dependentes dos Núcleos de Saúde da Família (NSF) do CSE-FMRP-USP e identificar algumas das dificuldades e necessidades enfrentadas por esses cuidadores, na realização das atividades de cuidado, e a sobrecarga que as mesmas exercem no corpo e na saúde deste indivíduo. O estudo foi realizado com 52 cuidadores das famílias cadastradas nos NSF, que responderam a um questionário com perguntas abertas e fechadas intitulado "Características dos cuidadores de idosos no contex to da Saúde da Família". As entrevistas foram realizadas no domicílio do cuidador, durante os meses de setembro e outubro de 2004. Os cuidadores eram predominantemente do sexo feminino, variando entre a faixa etária de 50 a 70 anos. A maioria era casada, isto é, dividia as responsabilidades da casa e da família com as atividades de cuidados. Quanto ao grau de parentesco com o idoso, a maior porcentagem ficou com as filhas, seguidas pelos cônju- ges. Quanto à presença de atendimento domiciliar, a maioria relatou estar recebendo assistência das equipes dos NSF. Para a maioria dos cuidadores, as atividades de cuidar de alguém doente, mais especificamente o idoso, foram aprendidas sozinhas, na prática, com base em erros e acertos. As dificuldades encontradas na realização das atividades domiciliares variaram conforme o grau de dependência do idoso e o suporte familiar que o cuidador recebeu. As alterações no corpo e na saúde, após o início das atividades como cuidador, variaram entre as físicas, como aparecimento de dores no corpo, principalmente na coluna, e alterações psicológicas e sentimentais como estresse, depressão, angústia e aumentos das preocupações. As observações gerais dos cuidadores sobre o processo de cuidar de alguém doente variaram entre os que acreditaram que estava bom e estavam conformados com a situação, e aqueles que relataram ser uma questão de obrigação, carinho e responsabilidade. Todas as informações analisadas confirmaram que o sucesso da manutenção, recuperação ou promoção da saúde ao idoso está diretamente relacionada com o preparo e amparo das pessoas que lhes prestam cuidado. O Programa de Saúde da Família surge, nesta nova perspectiva, como uma estratégia de reforma do sistema, proporcionando mudanças importantes nas ações, na organização dos serviços e na prática da assistência à saúde com a valorização do tema família.

\section{USO DE MEDICAMENTOS POR IDOSOS EM UM SERVIÇO DE SAÚDE DE RIBEIRÃO PRETO - SP}

\section{Mariana Honorato Giardini}

Orientadora: Profa. Dra.Elisabeth Meloni Vieira

Dissertação Mestrado apresentada em 25/02/2005
O conhecimento do paciente sobre os seus medicamentos é fundamental para que os use de forma a ser beneficiado por seus efeitos terapêuticos. A Or- 
ganização Mundial de Saúde (OMS) recomenda a prescrição de medicamentos como um parâmetro para conhecermos as características do uso de medicamentos nas populações. O presente estudo, uma investigação de corte transversal, teve o objetivo de analisar as características das prescrições médicas, utilizando por referência indicadores selecionados de prescrição da OMS, bem como avaliar o conhecimento sobre medicamentos prescritos a idosos cadastrados nos Núcleos de Saúde da Família ligados à Faculdade de Medicina de Ribeirão Preto da Universidade de São Paulo. Os indicadores de prescrição foram verificados nas receitas médicas e o conhecimento foi verificado através da aplicação de um questionário contendo perguntas relativas à indicação terapêutica do medicamento, nome, dosagem, quantidade de forma farmacêutica a ser administrada a cada vez e freqüência de administração. As respostas foram comparadas com a receita médica. $\mathrm{O}$ número médio de medicamentos prescritos por paciente foi de 2,76 . Foram dispensados $89,49 \%$ dos medicamentos prescritos, $91,30 \%$ foram prescritos pelo nome genérico e $90,94 \%$ foram prescritos de acordo com a lista padronizada de medicamentos. Foram prescritos $0,36 \%$ de antibióticos e $0,72 \%$ de medicamentos injetáveis. Do total de 100 entrevistados, $44 \%$ obtiveram um bom conhecimento sobre os medicamentos utilizados. No que se refere à dosagem, à quantidade de forma farmacêutica a ser administrada a cada vez e à frequiência de administração, 39\%, $87 \%$ e $85 \%$ das respostas, respectivamente, estavam de acordo com a prescrição médica. Em $87 \%$ dos casos, indicação terapêutica foi declarada corretamente e, em 45\%, o nome do medicamento estava correto. Os resultados sugerem que o Programa de Saúde da Família tem boa resolutividade no que se refere ao uso de medicamentos por idosos, mas que poderia melhorar em alguns aspectos através da atenção farmacêutica.

\section{CONDIÇÕES DE SAÚdE E DE HIGIENE BUCAL DOS PACIENTES COM CÂN- CER DE BOCA REFERENDADOS AO HOSPITAL DAS CLÍNICAS DA FACUL- DADE DE MEDICINA DE RIBEIRÃO PRETO - USP}

\author{
Maria Auxiliadora Macedo da Costa \\ Orientador: Prof. Dr. Antonio Luiz Rodrigues Júnior \\ Dissertação Mestrado apresentada em 25/02/2005
}

O objetivo deste trabalho foi avaliar as condições de saúde e higiene bucal dos pacientes com câncer de boca, referendados ao Hospital das Clínicas da Faculdade de Medicina de Ribeirão Preto, USP. Foram avaliados pacientes "casos novos" encaminhados ao Serviço de Cirurgia de Cabeça e Pescoço do HCFMRP - USP, durante o período de recrutamento da pesquisa, sendo examinados no Serviço Odontológico do mesmo hospital. A amostra totalizou 29 pacientes, dos quais foram coletadas informações através de questionário, exame clínico bucal e análise de prontuários. Para se avaliar a condição bucal foram usados os índices CPO-D, Índice Periodontal Comunitário, Índice de Higiene Oral Simplificado, Número e Índice de Dentes Funcionais e Índice Ambjorsen. As lesões foram classificadas quanto ao local, estadiamento e exame anátomo-patológico. Os resultados em relação aos dados sócio-demográficos, 75,86 \% pertencem ao sexo masculino, uma proporção de 3:1. Com relação à idade, o mais novo apresentava 42 anos, o mais velho 86 anos, média de 60,20 anos, sendo que a maioria estava compreendida na faixa etária entre 60 - 69 anos. Com relação à cor, 75,86 \% brancos e $24,14 \%$ não brancos (pardos e negros). Quanto à escolaridade, $27,60 \%$ analfabetos, $51,70 \%$ com acesso ao $1^{\circ}$ grau, $13,80 \%$ com acesso ao $2^{\circ}$ grau e $6,9 \%$ com acesso ao grau superior. A renda familiar foi de até 1 salário mínimo em $41,37 \%$, entre 2 - 3 salários mínimos em $27,58 \%$, entre 4 - 5 salários mínimos em $27,50 \%$ e maior que 5 salários mínimos em $3,5 \%$. O estado civil compôs $41,37 \%$ de casados e $58,63 \%$ de não casados. $69 \%$ dos pacientes não eram provenientes de Ribeirão Preto e $29,76 \%$ apresentavam atividades trabalhistas, sendo os demais, aposentados, desempregados, ou do lar. A condição bucal mostrou CPO-D médio de 28,89, índice dentes funcionais igual a 4,24. 37,93\% das pessoas apresentavam dentes funcionais. No IPC, 84,48 \% dos sextantes estavam excluídos. 71,42\% edentados totais e o IHOS pode ser examinado em poucas pessoas, pois não apresentavam dentes suficientes para exame e naqueles onde foi calculado, apresentavam higiene oral deficiente. Nos pacientes que usavam prótese, o Índice de Ambjorsen médio de 9,75. Localização da lesão mais frequiente na língua $(41,38 \%)$, carcinoma espinocelular 
96,55 \%. Hábitos de higiene bucal: 79,31\% costumavam limpar a boca e 51,72\% usavam escova e creme dental e 34,48\% escovavam 1 vez/dia. Freqüências aos serviços odontológicos, $82,76 \%$ tiveram acesso sendo 41,38\% em serviço público. 72,41\% consumiam álcool e em 85,71 \% bebida destilada. 96,55\% com exposição ao fumo.Apesar do estudo não apresentar uma amostra grande, ele indica que a condição bucal e social dos pacientes com câncer de boca é péssima. Sabendo-se que o câncer de boca é uma doença multifatorial, a situação encontrada é um alerta não apenas para os profissionais da saúde. Há necessidade de conscientização em saúde no seu mais amplo contexto, incluindo políticas públicas visando à educação, prevenção, diagnóstico precoce e tratamento do câncer de boca.

\section{REPRESENTAÇÕES DE MULHERES IDOSAS USUÁRIAS DE UM SERVIÇO DE SAÚDE: RELAÇÕES ENTRE CONSUMO DE CALMANTES, GÊNERO E ENVE- LHECIMENTO}

\section{Reginaldo Teixeira Mendonça \\ Orientadora: Prof ${ }^{a}$ Dr $^{\text {a }}$ Elisabeth Meloni Vieira \\ Dissertação de Mestrado apresentada em 4/03/2005}

Os calmantes benzodiazepínicos são intensamente consumidos no mundo e no Brasil, principalmente por mulheres com idade igual ou superior a 60 anos. O consumo de calmantes envolve fatores sociais, econômicos e culturais, fazendo com que a maneira de utilização seja adaptada à realidade de determinados grupos sociais. Objetivando analisar essas questões, fizemos uso, através de abordagem qualitativa, de entrevistas semi-estruturadas com dezoito mulheres idosas, pertencentes a classes populares e consumidoras desses medicamentos há mais de um ano. Assim, observamos que o modo de consumo dos calmantes é construído socialmente e essa construção é formada através do tempo de uso, da aproximação com os serviços de saúde, da classe social à qual pertencem seus consumidores, da definição social do papel da mulher na sociedade (no sentido de gênero) e do envelhecimento de seus usuários, acompanhado de experiências e conhecimentos sobre os medicamentos. As mulheres entrevistadas mostraram ter autonomia e conhecimento sobre o uso dos calmantes, sentindo-se capazes de utilizar, indicar, emprestar, ou não, esses medicamentos, de acordo com suas concepções. Pudemos, portanto, observar e analisar as interações entre os diversos fatores - socioeconômicos e culturais, gênero e envelhecimento - envolvidos nesse processo de utilização de calmantes. 


\section{TESES E DISSERTAÇÕES 2004}

\section{BIOQUÍMICA}

\section{CARACTERIZAÇÃO BIOLÓGICA DE UMA FRAÇÃO ANGIOGÊNICA DO LÁTEX NATURAL DA SERINGUEIRA HEVEA BRASILIENSIS}

\author{
Ricardo José de Mendonça \\ Orientador: Prof. Dr. Joaquim Coutinho-Netto \\ Dissertação de Mestrado apresentada em 20/04/2004
}

A angiogênese é um importante evento que ocorre durante o reparo tecidual e cicatrização. Ela também é importante no crescimento de tumores e na revascularização de tecidos submetidos à isquemia. Outro processo envolvido neste evento é o aumento da permeabilidade vascular, que permite a diversas citocinas e fatores de crescimento alcançarem o tecido lesado. Assim, tem sido sugerido que o látex extraído da seringueira Hevea brasiliensis possui atividade angiogênica o que levou-nos a trabalhar no sentido de iniciar a purificação do(s) componentes(s) ativo(s) presente no material e a caracterizá-lo, de forma a demonstrar sua atividade angiogênica e seu efeito sobre a permeabilidade vascular.

O extrato obtido a partir do látex (soro) tratado com $\mathrm{NH}_{4} \mathrm{OH}$ ( 2 a $7 \%$ ) foi submetido a uma primeira etapa de purificação em coluna de DEAE-celulose
(5X40cm) e eluída com tampão bicarbonato de amônio / cloreto de sódio em concentrações crescentes, na forma "stepwise". Desta cromatografia foram obtidas três frações que foram dialisadas e liofilizadas.

O efeito destas frações na permeabilidade vascular foi realizado pelo teste de Miles apresentando o pico I como o mais ativo em aumentar a permeabilidade vascular.

A atividade angiogênica foi analisada utilizando o teste na membrana cório-alantódea ovos de galinha (Galus domesticus). A fração um e dois (pico I e II) apresentaram maior atividade indutora de angiogênese.

O material extraído do látex (soro), foi fervido e tratado com proteases de forma a se analisar sua identidade química. A amostra perdeu sua atividade angiogênica e seu efeito sobre a permeabilidade vascular.

Assim chegamos a conclusão que o pico I é fração angiogênica e induz o aumento da permeabilidade vascular. $\mathrm{O}(\mathrm{s})$ componente(s) ativo(s) possui(em) a identificação química de proteína pois perdeu sua atividade após processos desnaturantes e tratamentos enzimáticos.

\section{ESTRESSE E FAGOCITOSE: PAPEL DA CORTICOSTERONA E CATECOLAMI- NAS NA FAGOCITOSE IMUNOLÓGICA DESEMPENHADA POR MACRÓFAGOS MURINOS}

\section{Gyselle Chrystina Baccan}

Orientador: Prof. Dr. Bernardo Mantovani

Tese de Doutorado apresentada em 05/11/2004

O sistema neuroendócrino pode modular algumas respostas imunológicas, inclusive a fagocitose. Apesar dos vários trabalhos sobre o efeito do estresse sobre a fagocitose, ainda há dúvidas se o estresse aumenta ou diminui a resposta fagocítica. Nós investi- gamos, em camundongos, a ação do estresse induzido pelo frio sobre a capacidade fagocítica de macrófagos peritoneais. Através de experimentos in vitro, nós também estudamos a ação da corticosterona e das catecolaminas na fagocitose mediada por diferentes receptores e comparamos macrófagos residentes com ativados por LPS. Nesses ensaios, com fagócitos não ativados, nós encontramos que o estresse agudo $\left(-15^{\circ} \mathrm{C} / 10 \mathrm{~min}\right)$ causou diminuição na fagocitose de eri- 
trócitos opsonizados com IgG (EA); o estresse prolongado $\left(4^{\circ} \mathrm{C} / 4 \mathrm{hs}\right)$ inibiu a fagocitose do EA e do zimosam. Ao contrário, em macrófagos ativados, o estresse aumentou a fagocitose do EA, EAC (eritrócitos opsonizados com complemento) e do zimosam. Os níveis plasmáticos de corticosterona e de catecolaminas dos animais estressados foram maiores que os dos controles. Nos experimentos in vitro, nós encontramos que a corticosterona diminui a fagocitose do EA (em ambos períodos de incubação); com o zimosam, este efeito foi observado apenas após a incubação de 4 h., em macrófagos não ativados. Entretanto, com fagócitos estimulados, esta droga diminuiu apenas a internalização do zimosam. As catecolami- nas não afetaram os macrófagos residentes, embora elas possam estimular a capacidade fagocítica dos macrófagos ativados. Experimentos com antagonistas adrenérgicos mostraram que este efeito estimulatório das catecolaminas poderia ser mediado por receptores $\alpha$-adrenérgicos. Nós encontramos que os efeitos observados com a corticosterona poderiam ser possivelmente atribuídos a uma ação não genômica deste hormônio, já que ele não é bloqueado por inibidores de transcrição e de tradução. Esta ação não genômica da corticosterona pode ser um importante fator de modulação dos processos fagocíticos com implicações nos mecanismos de defesa e talvez em outros processos fisiológicos.

\section{SAUDE NA COMUNIDADE}

\section{POLÍTICA DE SAÚde, SISTEMA ÚNICO DE SAÚdE E A PRÁTICA DO PRO- GRAMA DE SAÚDE DA FAMÍLIA NUM NÚCLEO ESPECÍFICO: LIMITES E DESAFIOS}

\section{Leon Markman Neto}

Orientadora: Profa. Dra. Vera Lucia Navarro

Dissertação de Mestrado apresentada em 28/01/2004

O objetivo desta pesquisa foi apreender o processo de trabalho de um Núcleo de Saúde da Família e sua correspondência com a filosofia do PSF. O nosso referencial teórico é o materialismo histórico-dialético e a Saúde Coletiva enquanto disciplina teórica e prática para a transformação da realidade no setor saúde e na sociedade. Trata-se, também, de uma abordagem qualitativa, onde utilizamos de instrumentos como a entrevista semi-estruturada, a observação e a inserção do pesquisador no campo de estudo. Para a análise do caso empírico de PSF, fizemos um recorte histórico no cenário das políticas sociais, para compreendermos a configuração atual das políticas de saúde. Neste sentido, estudamos o processo de intervenção do estado nas políticas sociais e em especial no setor saúde, considerando o período da primeira república até os dias atuais. Analisamos, o processo de Reforma Sanitária, suas implicações teórico-práticas que se materializaram com a construção do SUS. Examinamos a condução do projeto de Reforma do Estado, e sua vinculação com os ditames neoliberais, que repercutiram negativamente sobre a intenções democratizantes da Reforma Sanitária. Estes recortes nos permitiram compreender a implementação do SUS, principalmente quanto ao tema da descentralização e do financiamento, assim como a viabilização do PSF no cenário nacional. Documentos oficiais e textos de alguns dos críticos do PSF, foram debatidos num esforço de identificar a operacionalização de seus pressupostos e diretrizes. Foi aí que nos dedicamos a análise de um PSF em particular, o NSFIII, para identificar avanços, limites e desafios da proposta. Após a reunião do material empírico com a fundamentação teórica do PSF, foi possível identificar temas contraditórios, em termos de transformação das práticas em saúde, como a questão da intersetorialidade e da referência e a contra-referência. A análise global evidenciou aspectos divergentes do funcionamento do sistema de saúde e do PSF, mas também apontou, através do que os profissionais do NSFIII vem desenvolvendo, possibilidades potenciais de transformação das práticas em saúde. 


\section{VIOLÊNCIA DOMÉSTICA: PREVALÊNCIA ENTRE MULHERES USUÁRIAS DE UM SERVIÇO DE SAÚDE DE RIBEIRÃO PRETO - SP}

\author{
André Luis Valentim Marinheiro \\ Orientadora: Profa. Dra. Elisabeth Meloni Vieira \\ Dissertação de Mestrado apresentada em 04/02/2004
}

No Brasil, o número de estudos sobre violência doméstica contra a mulher, perpetrada pelo companheiro, ainda é escasso. Neste país, como em outros, este problema já foi apontado como sendo de saúde pública, devido suas consequências. Estas conseqüências não são restritas à saúde física, sexual e mental da mulher, mas também inclui problemas da dinâmica familiar, atingindo a sociedade em geral. Este estudo avalia a prevalência de violência doméstica contra a mulher, cometida pelo companheiro ou por outras pessoas, utilizando-se de questionário aplicado no próprio domicílio da mulher. Todas as mulheres entrevistadas tinham entre 18 a 49 anos de idade na época da consulta médica e eram usuárias do serviço de saúde. A prevalência de violência doméstica per- petrada pelo companheiro alguma vez na vida, referida pelas usuárias, foi de $45,3 \%$ para qualquer tipo de violência, que foi denominada de violência geral; $41,5 \%$ das mulheres referiram violência psicológica, $26,4 \%$ violência física e $9,8 \%$ violência sexual. O estudo demonstrou associação da ocorrência de violência doméstica com algumas características apresentadas pelas usuárias como: escolaridade, estado marital, idade da primeira relação sexual, dados sócio-econômicos, vida sexual e reprodutiva e companheiro controlador, além de determinados sinais e sintomas. Destes, alguns se relacionaram com a violência: infecção ginecológica de repetição, depressão, vontade de morrer. Estes resultados, comparados com a prevalência de violência encontrada no serviço de saúde através dos registros médicos, mostraram uma grande diferença. Isto corrobora com a necessidade de tornar o problema da violência contra a mulher mais visível para os profissionais da saúde.

\section{PREVALÊNCIA E FATORES DE RISCO PARA A INFECÇÃO DO HIV NA POPULAÇÃO CARCERÁRIA MASCULINA DA PENITENCIÁRIA DE RIBEIRÃO PRETO}

\section{Harnoldo Colares Coelho}

Orientador: Prof. Dr. Afonso Dinis Costa Passos

Dissertação de Mestrado apresentada em 13/02/2004

A infecção pelo HIV em presidiários alcança uma das maiores prevalências entre subgrupos populacionais específicos, com taxas de até $17 \%$ já tendo sido descritas no Brasil e no mundo. Contribuem para isso diversos comportamentos de risco, adotados já antes do encarceramento ou desenvolvidos durante o período de reclusão. Entre eles, destacam-se o uso de drogas ilícitas intravenosas, compartilhamento de agulhas e seringas e atividade sexual desprotegida. Esta pesquisa objetivou estimar a prevalência do marcador do HIV e fatores de risco para esta infecção na população masculina carcerária da Penitenciária de Ribeirão Preto - SP, no período de maio a agosto de 2003. Do total de 1030 presidiários, foram sorteados
333 participantes por amostragem casual simples, os quais foram submetidos à aplicação de um questionário padronizado e tiveram coletada uma amostra de sangue. Para diagnóstico sorológico do HIV foi utilizado inicialmente o ensaio imunoenzimático (ELISA), como teste de triagem, com a confirmação sendo feita através de reação de imunofluorescência indireta (IFI). A prevalência global encontrada para o HIV nos presidiários foi de 5,7\% ( $\mathrm{IC}_{95 \%}: 3,2-8,2$ ). Todas as variáveis que mostraram associação com a presença do anti-HIV, através de análise univariada, foram submetidas a um modelo multivariado de regressão logística utilizando o método Baysiano. Nesta análise, as variáveis que se mostraram preditoras de forma independente da infecção pelo HIV foram: presença de circuncisão, homossexualismo masculino, tempo total da pena a ser cumprida inferior a cinco anos, uso de droga injetável e compartilhamento de agulhas e seringas. 


\section{O USO DE BENZODIAZEPÍNICOS PELOS IDOSOS RESIDENTES NOS ASILOS DE UBERABA - MG}

\section{Luciana Lopes Navarro}

Orientadora: Profa.Dra. Amábile R. Xavier Manço

Dissertação Mestrado apresentada em 19/02/2004

O processo de envelhecimento populacional, ainda relativamente recente no país, necessita de estudos para melhor compreensão da sua dinâmica no organismo humano. Devido à prevalência das doenças crônico-degenerativas, os idosos são consumidores em potencial de medicamentos das mais variadas classes terapêuticas. Entre as classes mais utilizadas, estão os cardiovasculares e os psicofármacos. Este trabalho teve como objetivo caracterizar as instituições asilares do município de Uberaba, determinar a frequiência e o modo de utilização dos benzodiazepínicos pelos idosos asilados e levantar a justificativa dos cuidadores em administrar estes medicamentos. Todas as instituições asilares inscritas na Secretaria Municipal de Assistência Social foram pesquisadas. O método utilizado para a coleta dos dados foi entrevista semi-estruturada. Em uma entrevista, o diretor caracterizou a instituição, e em outra, o funcionário responsável pela medicação respondeu sobre o uso de ben- zodiazepínicos pelos idosos com 60 anos ou mais, residentes nas instituições. Foi detectada uma carência de registros sobre a saúde do idoso, dificultando assim, o esclarecimento de algumas questões. Os achados mostraram que $18 \%$ dos idosos faziam uso de medicamentos benzodiazepínicos, sendo que as mulheres foram as maiores usuárias. Houve maior número de usuários na faixa etária dos 80-89 anos de idade. Os benzodiazepínicos mais usados pelos idosos institucionalizados foram o diazepam e o clonazepam apresentando a freqüência de uso, $34 \%$ e $27 \%$, respectivamente, seguidos do lorazepam $(15 \%)$, bromazepam (12\%), midazolam (6\%), alprazolam e flunitrazepam com 3\%. Uma questão levantada neste trabalho foi o modo como estava sendo feito o armazenamento e o uso destes medicamentos. Assim, concluiu-se que o registro dos procedimentos dos profissionais em relação ao estado de saúde dos asilados é imprescindível para o seguimento dos mesmos, assim como a adoção de normas para um bom funcionamento da farmácia e para a administração dos medicamentos, visando promover um envelhecimento digno e saudável para os asilados

\section{TRABALHO RURAL E SAÚDE: UM ESTUDO DAS CONDIÇÕES DE TRABA- LHO E SUA RELAÇÃO COM A SAÚDE DOS CORTADORES DE CANA-DE- AÇÚCAR DO MUNICÍPIO DE PACAEMBU - SP}

\section{Cassiano Ricardo Rumin \\ Orientadora: Prof. ${ }^{a}$ Dr $^{\mathrm{a}}$ Vera Lucia Navarro \\ Dissertação de Mestrado apresentada em 22/02/2004}

A partir da década de 1990 a agroindústria sucroalcooleira expandiu-se da região nordeste do estado de São Paulo em direção ao oeste paulista. Além de alterar o perfil de produção agrícola do Oeste do Estado esta expansão determinou a impressão de seus padrões de exploração da mão-de-obra aos trabalhadores da região que foram absorvidos nesta atividade produtiva. Nesta pesquisa objetivamos investigar as condições de trabalho e sua relação com a possível ocorrência de danos ao quadro geral de saúde dos cortadores manuais de cana-de-açúcar do município de Pacaembu, situado no oeste do estado de São Paulo. Para a descrição das condições de trabalho foram realizadas observações diretas do processo de trabalho. Nestas ocasiões pudemos verificar aspectos inerentes às condições de trabalho, tais como a exposição ao calor e ao sol intensos e a velocidade de execução do trabalho. A produção de documentação fotográfica sobre o processo de trabalho foi utilizada com o objetivo de demonstrar as exigências posturais, as adaptações nos instrumentos de trabalho para atender às demandas de produtividade e as improvisações de vestimentas para proteger o corpo e reduzir o desgaste à saúde na colheita manual da cana-de-açúcar. Realizamos entrevistas semidirigidas individuais com 11 trabalhadores para a obtenção de informações sobre a organização do trabalho e possíveis adoecimentos 
relacionados a esta atividade produtiva. Outros elementos sobre o estado de saúde destes trabalhadores foram obtidos em entrevistas com um profissional da rede pública de saúde do município e em observações diretas das condições de habitação destes trabalhadores. Dados complementares foram obtidos pela revisão bibliográfica e a partir de informações do Instituto de Economia Agrícola. As entrevistas indicaram que na região estudada ocorre uma intensificação do ritmo de trabalho, tal como acontece em outras áreas do estado de São Paulo. Esta intensificação se expressa em quadros de morbidade comuns a estes trabalhadores: constante ocorrência de câimbras, lesões do sistema osteomuscular e do tecido conjuntivo e envelhecimento precoce. Outras morbidades relatadas nas entrevistas associadas ao padrão de desgaste ocupacional foram doenças do sistema gênito-urinário, vômitos, afecções respiratórias, desidratação e estresse. O não fornecimento de alimentos pelas empresas sucroalcooleiras aos trabalhadores durante a jornada de trabalho contribui para a degradação da saúde destes indivíduos podendo ocasionar quadros de desnutrição em virtude do elevado dispêndio energético relacionado a este trabalho. A extensão da jornada de trabalho superior a doze horas também contribui para o quadro de restrições alimentares, pois, caso o suprimento de alimento destinado à jornada de trabalho acabe ou sofra degradação, o trabalhador pode não possuir outra fonte para a reposição alimentar. A crescente mecanização da colheita da cana-de-açúcar ocasionou a redução dos rendimentos salariais em decorrência de dois fatores: menor oferta diária de matéria-prima para a colheita manual e disponibilidade de canaviais de menor rentabilidade, tal como onde os colmos são caídos e emaranhados para este trabalho. Podemos concluir que para estes trabalhadores houve uma degradação nas condições gerais de saúde e uma intensificação da atividade produtiva, além da ameaça crescente de desemprego em decorrência da mecanização da colheita.

\section{ESTUDO DA LEISHMANIOSE TEGUMENTAR AMERICANA NO ESTADO DO MATO GROSSO, NO PERÍODO DE 1994 A 1999}

\section{Emília Emiko Hayashi}

Orientador: Prof. Dr. Afonso Dinis Costa Passos

Dissertação Mestrado apresentada em 27/02/2004

A leishmaniose tegumentar americana (LTA) é uma doença de ampla distribuição no continente, constituindo importante problema de saúde pública na América Latina. No Brasil, são notificados cerca de 35 mil casos novos a cada ano, com maior distribuição nas regiões Centro-Oeste, Norte e Nordeste. A doença têm uma forte associação com desmatamentos e o estabelecimento de contingentes populacionais em áreas recentemente desbravadas. A região CentroOeste do País, notadamente o estado do Mato Grosso, sofreu nas últimas décadas um intenso processo de ocupação desordenada do seu território, passando a mostrar um número progressivamente elevado de casos de LTA. Este trabalho objetivou descrever a evolução da moléstia no Mato Grosso durante o período 1994 a 1999, utilizando dados secundários produzidos na rotina das atividades da Fundação Nacional de Saúde (Funasa) relativos às 4 áreas distritais em que o Estado era dividido: Distritos 1 (Cáceres), 2 (Nortelândia), 3 (Rondonópolis) e 4 (Sinop).
Excluindo-se o ano de 1998, em que problemas operacionais relacionados à distribuição de medicamentos reduziram a notificação de casos, os coeficientes de incidência (10 mil) variaram de 16,5 (em 1997) a 20,6 (em 1999). A LTA mostrou-se crescente no Estado, com todos os municípios apresentando casos em 1999. Em todos os distritos e ao longo de todo o período do estudo, as maiores incidências foram observadas em homens acima de 20 anos de idade. Verificouse uma distribuição diferenciada da LTA segundo as áreas distritais, com Cáceres mostrando os valores mais reduzidos (5,0 a 5,6 por 10 mil), Rondonópolis com valores intermediários $(12,7$ a 14,5 por 10 mil $)$ e Nortelândia e Sinop com valores elevados (32,6 a 44,5 e 29,2 a 55,2 por 10 mil, respectivamente). Os baixos valores em Cáceres devem-se, provavelmente, ao fato de corresponder a uma população mais estabilizada. Em contrapartida, os distritos de Nortelândia e, especialmente, Sinop, compreendem áreas que sofreram intenso processo de colonização em anos recentes, com desmatamento para expansão da fronteira agrícola, construção de rodovias e grande afluxo populacional, fatores que explicam os elevados coeficientes de incidência. 
Os resultados do trabalho mostram que a LTA é uma endemia de grande relevância no Mato Grosso, com transmissão ocorrendo em todo o seu território e de maneira ascendente nos últimos anos da série es- tudada. A evolução progressiva da doença se fez de modo mais intenso na área do Distrito 4 (Sinop), onde, em 1999, 12 municípios apresentavam coeficientes de incidência acima de 100 casos por 10 mil habitantes.

\section{DISPÊNDIO ENERGÉTICO, PERFIL ANTROPOMÉTRICO, IDADE E CONDI- ÇÕES SOCIOECONÔMICAS DE MULHERES NA FAIXA ETÁRIA DE 40 A 64 ANOS, CADASTRADAS NO PROGRAMA DE SAÚDE DA FAMÍLIA, NA CIDA- DE DE RIBEIRÃO PRETO}

\section{Liliana Figueiredo Andrade de Oliveira Ramos Orientador: Prof. Dr. Milton Roberto Laprega \\ Dissertação de Mestrado apresentada em 27/02/2004}

Objetivo: Esse estudo teve como objetivo verificar as associações entre dispêndio energético (Kcal), perfil antropométrico (índice de massa corporal (IMC) e relação cintura/quadril (RCQ)), idade e condição socioeconômica (grau de escolaridade e renda per capita) de mulheres, na faixa etária de 40 a 64 anos, cadastradas no Programa de Saúde da Família.

Metodologia: A amostra contituiu-se de 147 mulheres, que responderam a um inquérito domiciliar, com intuito de avaliar o dispêndio energético e as condições socioeconômicas e em seguida foram realizadas as medidas antropométricas. Com exceção do dispêndio energético, as demais variáveis foram categorizadas para processar o teste de Kruskal-Wallis, adotando um nível de significância de $5 \%(\alpha=0,05)$ para as tomadas de decisão.
Resultados: O dispêndio energético apresentou relação direta ao IMC $(p=0,0001)$ e inversa aos graus de escolaridade $(p=0,0407)$ e idade $(p=0,0417)$, mas não se verificou associação em relação à RCQ $(p=0,1288)$ e renda per capita $(p=0,1984)$. Também não foram encontradas associações para as análises entre IMC e renda per capita $(p=0,8263)$, grau de escolaridade $(p=0,1326)$ e idade $(p=0,7423)$. Na avaliação da RCQ foi observada uma relação inversa à renda per capita ( $p=0,0163)$, não se apresentou associação com a idade $(p=0,5985)$ e embora tenha demonstrado diferença estatística $(p=0,0126)$ em relação aos graus de escolaridade, os resultados foram discordantes da literatura.

Conclusão: As mulheres estudadas apresentaram alta prevalência de sedentarismo $(57,8 \%)$, sobrepeso $(31,3 \%)$ e obesidade $(36,0 \%)$. Possuem RCQ inadequada e baixo nível socioeconômico. Propõe-se que os resultados sejam discutidos no Programa de Saúde da Família, com o intuito de criar políticas públicas para a promoção da saúde.

\section{ESTUDO DOS FATORES RELACIONADOS COM A ADESÃO AO TRATAMEN- TO FARMACOLÓGICO ANTI-HIPERTENSIVO EM PACIENTES IDOSOS}

\section{Débora Faleiros Chioca Vieira}

Orientador: Prof. Dr. Laércio Joel Franco

Dissertação Mestrado apresentada em 02/12/2004

Estima-se que a adesão dos pacientes à farmacoterapia anti-hipertensiva varie entre 50-70\%. Avaliações do comportamento de adesão ao tratamento são necessárias para um planejamento efetivo e eficiente. Este estudo tem como objetivo analisar a adesão ao tratamento farmacológico em pacientes hipertensos atendidos no Centro de Convivência do Idoso, no município de Franca-SP. Foram entrevistados 100 pacientes, sendo 50 homens e 50 mulheres e foram incluídos apenas os que estavam utilizando medicamentos anti-hipertensivos distribuídos pelo Sistema Único de Saúde do município. Foi utilizada a Escala de Morisky e Green para mensurar a adesão individual ao tratamento farmacológico. Os grupos foram definidos segundo os resultados obtidos nessa escala, através do Critério 1. Foram consideradas variáveis indepen- 
dentes aquelas que poderiam estar relacionadas ao grau de adesão, como: atitude frente à tomada de medicamentos; características sócio-demográficas; hábitos de vida; características de saúde; características dos medicamentos anti-hipertensivos; uso de medicamentos em geral; características do serviço de saúde; características do paciente; nível de informação sobre a doença e o seu tratamento; controle da pressão arterial (controlado e não-controlado). O processamento dos dados foi efetuado pelo programa Epi-Info 2002 e no STATA. As análises foram feitas de acordo com os resultados do Teste de Morisky e Green, segundo as variáveis citadas. Observou-se grande predomínio de baixa escolaridade e baixa renda familiar mensal no grupo estudado. Em relação ao controle da pressão arterial, observou-se que $63 \%$ dos pacientes estavam controlados. A comparação entre os resultados do Teste de Morisky e Green com os de controle da pressão arterial revelou que não há associação estatística entre eles, com ambos os critérios do TMG. Pelo Critério 1, foram classificados $40 \%$ dos pacientes como menos aderentes e $60 \%$ como mais aderentes. Através do Critério 2, foram encontrados os valores de $70 \%$ e $30 \%$, respectivamente. Em relação à atitude frente à tomada de medicamentos, verificou-se que $35 \%$ dos pacientes apresentavam atitude negativa e $65 \%$, positiva. A comparação dos resultados do TMG, empregando os Critérios 1 e 2 e os grupos com "atitude positiva" e "atitude negativa" evidenciou associação es- tatisticamente significante em ambos os critérios. Entretanto, a sensibilidade do teste quando utilizado o Critério 2 foi muito alta $(94,3 \%)$, com uma especificidade baixa $(43,1 \%)$, o que pode gerar a identificação de muitos pacientes como falsos positivos. O instrumento para avaliar a atitude do paciente frente à tomada de medicamentos apresentou significância estatística nas comparações entre os "mais aderentes" e "menos aderentes", quanto à seguintes questões: "Toma o medicamento sempre no mesmo horário"; "Providencia outra caixa antes da que tem em casa acabar"; "Toma os medicamentos mesmo quando a pressão está controlada"; "Deixou de tomar os medicamentos nos últimos 30 dias”. Em relação às possíveis causas da não-adesão, foi associado o fato do paciente ter medo de sofrer queda de pressão arterial após tomar os medicamentos. Além disso, também foram associadas as seguintes questões: "Tem dificuldades para lembrar os horários das tomadas dos medicamentos"; "Toma os medicamentos mesmo quando está se sentindo bem"; "Deixa de tomar comprimidos por conta própria". Os dados apresentados evidenciam que a adesão ao tratamento farmacológico é um padrão de comportamento individual, que reflete as crenças e medos pessoais, em relação aos danos causados pela doença e vantagens do tratamento medicamentoso. Fator importante, que pode estar relacionado à faixa etária estudada é o esquecimento das doses e horários dos medicamentos.

\section{ESTUDO DO DESENVOLVIMENTO NEUROPSICOMOTOR DE CRIANÇAS FILHAS DE MÃES SOROPOSITIVAS PARA O HIV NO MUNICÍPIO DE 227-228RIBEIRÃO PRETO, SP}

\section{Silvia Fabiana Biason de Moura Negrini}

Orientador: Prof. Dr. Jair Licio Ferreira Santos

Dissertação de Mestrado apresentada em 09/12/2004

O panorama epidemiológico da AIDS indica a expansão da epidemia entre mulheres e conseqüientemente a infecção de crianças através da transmissão vertical. As crianças acometidas pela AIDS podem apresentar diversos sintomas e sinais próprios da doença, entre eles, atraso no desenvolvimento neuropsicomotor. No entanto, crianças filhas de mães soropositivas mesmo quando não infectadas, podem sofrer as consequiências da doença em sua família. Os obje- tivos deste estudo foram: comparar o desenvolvimento neuropsicomotor de crianças não infectadas filhas de mães soropositivas para o HIV com crianças não expostas ao vírus; identificar fatores para atraso no desenvolvimento destas crianças e refletir sobre a necessidade de intervenção pela terapia ocupacional. Foram comparados dois grupos, com 45 crianças em cada um deles, nas idades de 3, 8 e 18 meses. Em relação ao desenvolvimento neuropsicomotor não foram encontradas diferenças entre o grupo de crianças filhas de mães soropositivas para o HIV e crianças não expostas ao vírus nas idades em conjunto, porém foi encontrada diferença significativa entre eles na idade de 3 meses. Também foram encontradas diferenças 
significativas entre os grupos quando comparados quanto à renda familiar, ao peso da criança ao nascimento e ao hábito materno da utilização de drogas ilícitas. Contudo, aos 3 meses de idade, apenas o hábito materno da utilização de drogas ilícitas influenciou negativamente o desenvolvimento neuropsicomotor das cri- anças. Os resultados permitiram discutir o papel do terapeuta ocupacional junto a esta população e sugere-se que novos estudos envolvendo o tema poderão colaborar com a confirmação dos dados obtidos, bem como dar continuidade às reflexões sobre a atuação deste profissional.

\section{ESTUdO DE ALGUMAS ETAPAS DO PROCESSO DE SELEÇÃO DOS PRIMO DOADORES DE SANGUE DO CENTRO REGIONAL DE HEMOTERAPIA DE RIBEIRÃO PRETO, SP}

\section{Cláudia Menezes Salles Spano}

Orientador: Prof. Dr. Afonso Dinis Costa Passos

Dissertação de Mestrado apresentada em 22/12/2004

No período de março a maio de 2004 , foram estudados 351 primo doadores de sangue do Centro Regional de Hemoterapia de Ribeirão Preto (CRHRP), objetivando investigar os seguintes itens: adequação do tempo utilizado na triagem clínica; entendimento acerca do processo de auto-exclusão e de suas implicações; compreensão sobre as orientações contidas em material informativo, de modo particular em relação ao conceito de janela imunológica; entendimento do termo de consentimento e suas implicações; e entendimento com relação aos comportamentos de risco para a AIDS e para as hepatites B e C.

Os participantes foram entrevistados após o término da doação, com as informações sendo obtidas através da aplicação de um questionário e da busca junto à Central de Processamentos de Dados do CRHRP. As entrevistas foram realizadas em todos os dias da semana e durante o horário de funcionamento do Serviço, das 7:00 as 13:00. Nos dias em que o número de primo doadores ultrapassou a capacidade de aplicação do questionário, a escolha dos participantes foi realizada através de sorteio.

As variáveis grau de instrução, número de doadores por dia, tempo médio utilizado na triagem clínica e triador foram determinantes para quantificar e qualificar o entendimento dos doadores com relação ao processo de seleção.

Verificou-se que $11,4 \%$ dos doadores não recebeu o material informativo, e, dos que o receberam, $21,2 \%$ não realizou a leitura. O tempo médio gasto na triagem clínica foi igual ou inferior a 3 minutos em cerca de $42,7 \%$ dos casos, com variabilidade de 1,2 a 18,2 minutos. Boa compreensão do termo de consentimento e do conceito de janela imunológica ocorreu em $54,4 \%$ e $35,3 \%$ dos doadores, respectivamente. Evidenciou-se um nítido contraste de boa compreensão sobre comportamento de risco para AIDS e para hepatites $\mathrm{B}$ e $\mathrm{C}$, com valores respectivamente iguais a $81,5 \%$ e $8,6 \%$.

Os resultados apontam para a necessidade de aprimoramento do processo de triagem clínica, bem com de novas pesquisas que contribuam para melhorar o entendimento acerca dos determinantes das deficiências verificadas. 